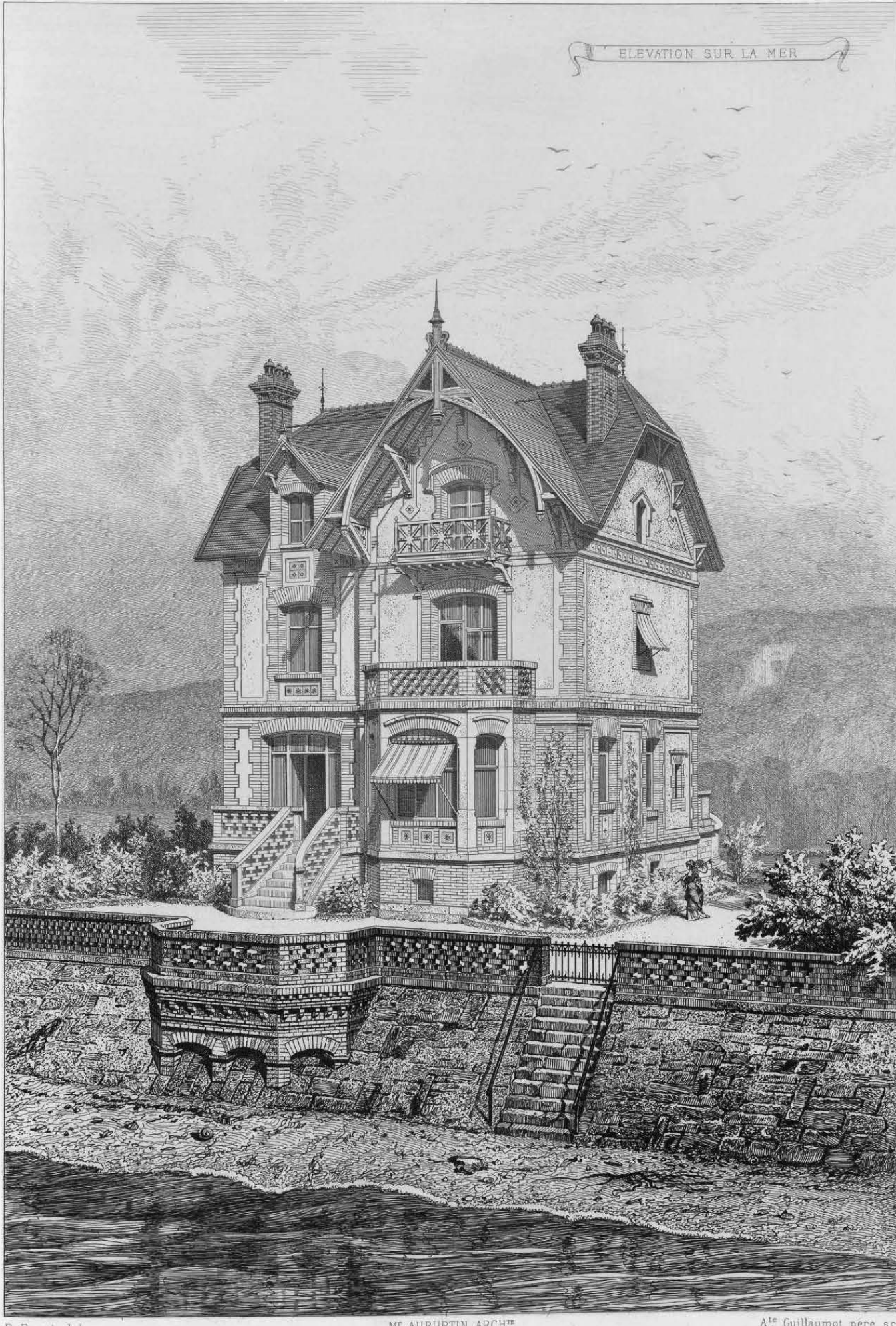

P. Faure del

MP AUBURTIN ARCH:

Ate Guillaumot pere

VILLA

A HOULCATE - (CALVADOS) 


\section{El legado de ultramar. Identidađ, tradición e innovación en la configuración exterior de la casa indiana gallega}

Overseas Heritage: Identity, Tradition, and Innovation in the Exterior Configuration of Indiana Houses in Galicia

\section{Resumen}

El presente trabajo se centra en la arquitectura doméstica indiana gallega, como consecuencia del primer gran movimiento migratorio producido entre la segunda mitad del siglo XIX y las primeras décadas del XX. Se reflexiona sobre los diferentes factores que influyeron en su composición como pudieron ser las posibles fuentes escritas, enriquecidas con la incorporación de repertorios de imágenes que aportaron modelos de fachadas, así como otros elementos arquitectónicos y decorativos. También se analizan otros puntos como las influencias estilísticas, gustos
Miriam Elena Cortés López

Universidade de Santiago de Compostela, Espańa miriamelenac@gmail.com https://orcid.org/0000-0002-8617-1112

Cómo citar este trabajo / How to cite this paper:

Cortés López, Miriam Elena. "El legado de ultramar. Identidad, tradición e innovación en la configuración exterior de la casa indiana gallega." Atrio. Revista de Historia del Arte, no. 25 (2019): 170-207.

(c) 2019 Miriam Elena Cortés López. Este es un artículo de acceso abierto distribuido bajo los términos de la licencia Creative Commons Attribution-NonCommercial-ShareAlike 4.0. International License (CC BY-NC-SA 4.0).

* El presente artículo se inscribe en el marco del proyecto de investigación titulado "CEAl: Canon Europeo de Arquitectura Indiana". (IP. Iván Moure Pazos), promovido por el Plan Galego de Investigación, Innovación e Crecemento de la Xunta de Galicia.

Dado el gran número de casas que se van abordar en el presente trabajo, se adjunta como anexo un inventario de todas ellas, reflejándose su identificación, año de construcción y territorio en el que se ubican. Para una mayor comprensión del presente artículo, se recomienda una consulta paralela. 
personales o la intervención de profesionales en el proyecto. Finalmente, se comparan las formas, estructuras y repertorios decorativos que hacen singulares estas casas, localizadas a lo largo del territorio gallego, especialmente en núcleos próximos al litoral. Palabras clave: arquitectura indiana; Galicia; diseños; decoración; fachadas. we will compare the forms, structures, and decorative ornaments that make these houses, located throughout Galicia and especially in coastal areas, unique.

Keywords: indiana architecture; Galicia; designs; ornament; facades.

\section{Contexto de la arquitectura indiana en Galicia}

En 1893 un jovencísimo Frank Lloyd Wright (1867-1959) proyectaba la que sería conocida como su primera casa correspondiente a la serie de "Prairies Houses". Su construcción —y las que poco tiempo después le sucedieron - supuso un revulsivo para la historia de la arquitectura a nivel mundial. Este significativo suceso se produjo en el continente americano, suponiendo una ruptura con los sistemas tradicionales de construcción, aquellos que escasas décadas antes se recogían en la obra escrita de A. J. Downing. La casa de William H. Winslow (River Forest, Illinois), con su sobriedad y elegancia constructiva, responde al esquema de vivienda unifamiliar independiente rodeada de naturaleza viva y que se complementa con construcciones anexas. Lo que en el continente europeo se denominaría chalet, cottage o casa de campo. ${ }^{1}$

En esa misma década, en la costa atlántica española, concretamente en la población de A Guarda (Pontevedra), se estaba construyendo Villa Domínguez, tipología de vivienda unifamiliar que constituye un ejemplo habitual en la época, que en este caso se concibe bajo prototipos procedentes de la tradición barroca europea, e interpretados bajo los códigos y pautas estilísticas propias del eclecticismo. La peculiaridad de esta casa, entendida como un palacete, radica en la impresión que debió de causar en la humilde población inmediata. Y es que su promoción se debe a un indiano, americano, habanero o brasileiro que, como ya se ha señalado en diversas ocasiones, ${ }^{2}$ es el término con el que se identifica a quien emigró en busca de trabajo al continente americano (habitualmente al Sur) que en algunas ocasiones retorna a su lugar de origen, una vez que ha conseguido enriquecerse, con el fin de vivir cómodamente el resto de su vida y, en ocasiones concretas, ayudar a la población mediante labores benefactoras tales como la promoción de obra privada, pública y social. ${ }^{3}$

El gran fenómeno migratorio gallego se desarrolló con fuerza desde la segunda mitad del siglo XIX hasta la década de 1930, y fue especialmente acusado en los núcleos poblacionales del litoral gallego. Los destinos de trabajo preferentes fueron Cuba (Coruña y Lugo), Argentina (Pontevedra), Brasil (Ourense), Uruguay, Puerto Rico y, ocasionalmente, Florida. Este hecho tendrá consecuencias directas en determinados aspectos del diseño de este tipo de viviendas. Por otro lado, se ha calculado que aproximadamente 1.200.000 de gallegos emigraron en la franja temporal que oscila de 1900 a 1930. Entre 1887 y 1895 ya lo habían

1. Bruce Brooks Pfeiffer, F. L. Wright. 1867-1959. Construir para la democracia (Köln: Taschen, 2004), 16-17.

2. Carlos Sixirei Paredes, "Habaneros," en Casas de Indianos, ed. Fernando Bores Gamundi (Santiago de Compostela: Xunta de Galicia, 2000$), 16-17$.

3. Domingo González Lopo, "Los Frutos de la emigración, las fundaciones filantrópicas de los indianos gallegos," en Galicia e América: cinco siglos de historia (Santiago de Compostela: Consellería de Relacións Institucionais e Portavoz do Goberno, Consello da Cultura Galega, 1992), 213-16; Vicente Peña Saavedra, "Das fundacións docentes dos indianos ás escolas de americanos, catro séculos de intervención escolar dos emigrantes galegos," en I Encontros Galicia-América, eds. Roberto Irimia-Vázquez y Juan Francisco Froján Fontán (Santiago de Compostela: CIHUGA, 1992), 53-79; Vicente Peña Saavedra, "Educar: el compromiso de la añoranza fecunda: entre la filantropía docente de los "indianos" y la obra escolarizadora de las Sociedades de Instrucción (SS. XVI-XXI)," en Ciudadanos españoles en el mundo: situación actual y recorrido histórico (Vigo: Grupo España Exterior, 2008), 55-102. 
hecho alrededor de $150.000 .{ }^{4}$ No todos se enriquecieron, ni todos regresaron, pero los que lo hicieron dejaron la impronta del trabajo realizado en las "Américas" sobre el territorio gallego, teniendo su traducción material en lo que el "oro americano" permitió construir: escuelas, hospitales, carreteras, lavaderos... Solo así se entienden fortunas como las de los hermanos García Naveira en Betanzos, ${ }^{5}$ la familia de los Moreno en Ribadeo $^{6}$ (estos nunca regresaron), García Barbón en Vigo ${ }^{7}$ o los Pernas en Viveiro. ${ }^{8}$

\section{La arquitectura de indianos en Galicia}

\section{El concepto ¿Estilo propio o cuestión social?}

Es en el marco contextual de esta situación concreta (el retorno de los emigrados) donde se concibe la construcción de determinadas casas, villas, chalets o edificios que por su organización, composición o recursos ornamentales, destacan sobre el resto de las construcciones populares. Pero como ha sido sugerido en ocasiones, la arquitectura que tradicionalmente se califica como indiana, no se debe interpretar como un estilo único, singular o destacado, equiparable al Gótico, el Barroco o el Neoclasicismo. Más bien participa de todas aquellas corrientes historicistas, "neoestilos" que oscilan desde el recuerdo a modelos ingleses, franceses, italianos o regionales, hasta el empleo de determinados recursos más novedosos, procedentes del Modernismo. No sería adecuado emplear el término estilo indiano, entendido como una corriente artística que responde a unos parámetros cerrados y concretos, que a su vez son comunes a todas esas casas promovidas con el dinero americano. El gallego retornado —al igual que sucede en cualquier otro núcleo migratorio de Espańa como Asturias, Cantabria, País Vasco, Andalucía o incluso en Portugal — no crea un estilo peculiar, exclusivo o único, que lo diferencie de otra obra decimonónica contemporánea de promoción burguesa. ${ }^{9}$ En resumen, la arquitectura indiana no es una cuestión estilística, formal o tipológica, sino que alude a la condición de su promotor. ${ }^{10}$

Lo que sí los hace destacar sobre los demás —y para ello no en todos los casos- es su deseo por diferenciarse sobre el resto de la población, exhibiendo su triunfo. Solo así se entienden oníricos ejemplos como la Villa Isabel (Oleiros, 1899), la Torre de los Moreno (Ribadeo, 1912), Villa El Fondón (Viveiro, 1927), Villa Canido (Ferrol, 1923) o la ya arruinada Casa de Valeriano Portela Rodríguez (Camposancos, 1894). En todos ellos, no solo se combinan diversidad de volúmenes verticales y horizontales, que en la mayoría de los casos dibujan plantas de perímetro irregular; sino que como complemento a esta estructura inicial se hace uso de un repertorio decorativo que se mueve dentro de los parámetros de diversidad de corrientes estilísticas, desde el eclecticismo a los historicismos, pasando por el Modernismo o el Art Decó. ${ }^{11}$ En ocasiones extraordinarias, también es posible apreciar determinados elementos procedentes de la arquitectura autócto-

\footnotetext{
4. Óscar Castro García, "Arquitectura doméstica indiana en Galicia," en Indianos. Arquitectura da emigración na península de Bezoucos: Ares, Cabanas, Fene e Mugardos, eds. Bernardo Anatol Seoane y Carlos Ardá Suárez (Ferrol: COAG, 2000), 14.

5. Santiago de la Fuente García, "Los Hermanos García Naveira y sus fundaciones," Anuario Brigantino, no. 22 (1999): 395-434; Fernando Salgado, "Los hermanos García Naveira," en Historias de Galicia. La riqueza que emergió del mar (A Coruña: La Voz de Galicia, 2017), 3:265-70; Aurora Alonso de Rocha, "Los hermanos García Naveira, indianos: nota-homenaje," Anuario Brigantino, no. 39 (2016): 343-82; Teresa Rocamonde, "Os irmáns García Naveira, empresarios na Arxentina e filántropos en Betanzos," Eco: revista do Eixo Atlántico, no. 327 (2018): 44-49.

6. Diego Rodríguez Paz, "La Torre de los Moreno en Ribadeo: un ejemplo singular de la arquitectura indiana en Galicia," Anuario Brigantino, no. 33 (2010): $337-92$.

7. Xosé Ramón Iglesias Veiga, Arquitectura e indianos na cidade de Vigo e Bisbarra (Vigo: Instituto de Estudios Vigueses, 2013 ), 36-39.

8. Bores Gamundi, Casas de Indianos, 583.

9. Covadonga Álvarez Quintana, "La casa indiana," Obradoiro, no. 10 (1984): 46.

10. Covadonga Álvarez Quintana, Indianos y arquitectura en Asturias (Gijón: COAATA, 1991); Iglesias Veiga, Arquitectura e indianos na cidade de Vigo e Bisbarra, 13; Castro García, "Arquitectura doméstica," 14.

11. Como en su día ya hizo notar Antonio Garrido, es mucho menos habitual el desarrollo de estructuras y repertorios racionalistas. Señala el autor que ello puede deberse a una razón de corte cronológico. Antonio Garrido Moreno, "A imaxe arquitectónica dos indianos galegos," Estudios Migratorios, no. 11-12 (2001): 328.
} 
na americana. Además, en bastantes casos se percibe la necesidad por ubicar la casa en un terreno exclusivo, con dominio visual sobre el entorno inmediato, situado en promontorios, valles y con vistas al mar, cuando no en puntos neurálgicos del centro de las ciudades. Parece evidente que conseguir una arquitectura de estas características está al alcance de unos pocos, de aquellos que tienen un elevado status económico.

\section{De arquitectos, repertorios y prototipos}

En la configuración de la casa intervienen varios factores. El primero de los cuales es su encargo. La práctica habitual fue contratar la planificación de estas casas a un maestro de obras y solo en aquellos casos más reseñables se eligió a un arquitecto titulado. ${ }^{12}$ Juan Ciórraga, Rodolfo Ucha Piñeiro, Julián García Núñez o Jenaro de la Fuente fueron algunos de los proyectistas seleccionados. ${ }^{13}$ Existen casos concretos en los que el propio promotor de la obra, quizá por tener conocimientos previos de construcción, se encarga parcialmente de realizar el proyecto, como sucede con Antonio Fernández y la Casa del Adriano (Barallobre, 1921). Cuando se hace el encargo a los profesionales mejor cualificados, el estilo que caracteriza su trabajo se aprecia en determinadas partes y elementos de la construcción. Sin embargo, en otras ocasiones resulta complicado poder establecer el origen del diseño o localizar sus planos. Cabe pensar que no han sido pocas las ocasiones en las que el indiano ha podido recurrir a álbumes de repertorios gráficos, imágenes de diseños de casas que se difundían en revistas especializadas, o algún proyecto importado. Incluso podría tratarse de dibujos esbozados, realizados por él mismo, copiados de algunos palacetes situados en barrios de lujo como el Vedado en La Habana, o determinadas áreas del Río de la Plata (Uruguay-Argentina), así como otras zonas de Chile, Brasil o Puerto Rico. ${ }^{14}$ En este contexto es donde se podrían comprender casas como las del núcleo de la península de Bezoucos (Ares, Cabanas, Fene y Mugardos), con un notable número de vecinos que emigraron a Cuba, sobresaliendo ejemplos como la excelsa Villa Amalia en Redes (Ares, 1919) o El Chalet do Seixo en Mugardos que presenta la peculiaridad de ser la primera casa de la zona catalogada como indiana (1860).

Próximas en el territorio, estas dos casas son ejemplo de la diversidad de modelos que ha procurado la arquitectura de indianos pues, aunque partiendo de una estructura rectangular que las aproxima a la casa tradicional gallega, ${ }^{15}$ Villa Amalia se envuelve con un repertorio ornamental de corte ecléctico, en tanto que en la Casa de Mugardos se percibe una influencia que la aproxima a la tradición pintoresca, que puede tener un punto de conexión con la idea de cottage inglés o de chalet suizo. En esta última línea se pueden inscribir casas como Villa Enedina (Cariño, 1900), la Casa Verde (Ponte Caldelas, 1895), O Meu Repouso (Gaxate, A Lama, 1915) o la Casa del Señorón (Ourol, ha. 1930). Este grupo de viviendas podría hacer reflexionar

12. Oscar Castro García, "Arquitectura doméstica indiana en Galicia. Los autores de los proyectos arquitectónicos," en Galicia-Cuba: Un patrimonio cultural de referencias y confluencias, eds. Concepción Fontenla San Juan y Manuel Silve (Sada: Ed. do Castro, 2000), 63-69. Algo similar sucede en el caso asturiano. Véase Álvarez Quintana, "La casa indiana," 48-49; Garrido Moreno, "A imaxe arquitectónica," 328.

13. Estudios sobre la obra de estos autores en: José Manuel López Vázquez, "Juan de Ciórraga y Fernández de la Bastida," en Galicia. Arte, ed. Francisco Rodríguez Iglesias (A Coruña: Hércules, 1993), 15: 143-44; José Ramón Soraluce Blond, "La arquitectura ecléctica en Galicia," Abrente, no. 35-37 (2005): 183-226; Bernardo Castelo Álvarez, "Rodolfo Ucha Piñeiro," en Arquitectura modernista, ecléctica e rexionalista, ed. Antón Pulido Novoa (Vigo: Nova Galicia Ed., 2002), 95-149. Fernando Agrasar Quiroga y Alfredo Vigo Trasancos, Rodolfo Ucha Piñeiro: construíndo Ferrol (Ferrol: Concello de Ferrol, 2014); Ramón Gutiérrez, José Ramón Alonso Pereira, y Fernando Álvarez, coords., Julián García Núñez: Caminos de ida y vuelta (Buenos Aires: Cedodal, 2005); Jaime Garrido Rodríguez, Jenaro de la Fuente Domínguez: el gran artífice del ensanche vigués y su abundante obra arquitectónica (Vigo: Instituto de Estudios Vigueses, 2016).

14. Iglesias Veiga, Arquitectura e indianos na cidade de Vigo e Bisbarra, 14-15.

15. Plácido Lizancos Mora, "A aventura americana na conformación da vivenda e outras arquitecturas de Galicia. Percorrido histórico," en Fontenla y Silve, GaliciaCuba: Un patrimonio cultural de referencias y confluencias, 37-46; Plácido Lizancos Mora, "Influencia das migracións na vivenda galega contemporánea," en Identidades Multiculturais, eds. Ana Bringas López y Belén Martín Lucas (Vigo: Servicio de Publicacións Universidade de Vigo, 2000), 233-40; Jesús Ángel Sánchez García, "Entre la persistencia de lo autóctono y la seducción por lo foráneo. Espacios residenciales en Galicia en los siglos XIX y XX (pazos, quintas, villas y chalets)," en Espais Interiors. Casa i Art des del segle XVIII al XXI, eds. Rosa Creixell, Terese M. Sala, y Esteve Castañer (Barcelona: Publicacions i Edicions, Universitat de Barcelona, 2007), 233-44. 


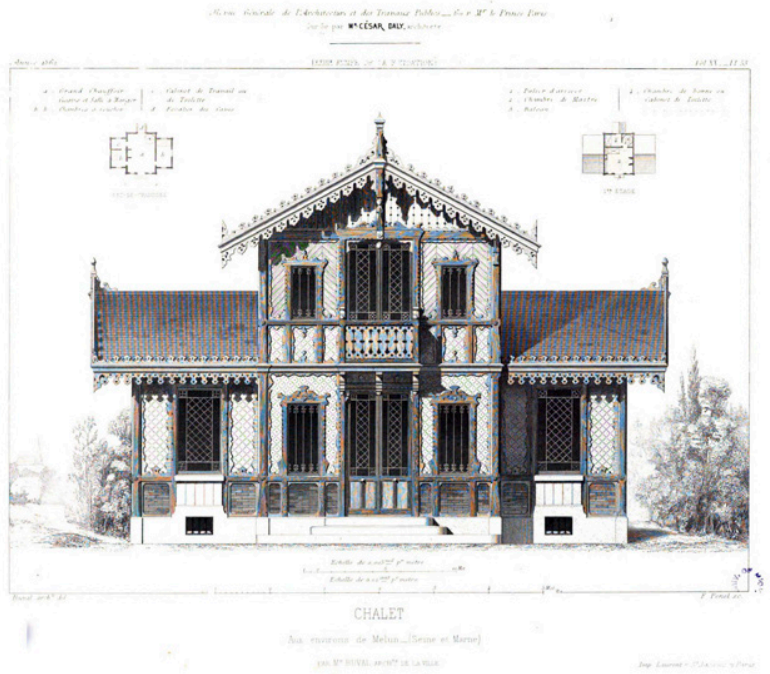

Fig. 2. Casa según C. Daly. Revue Generale de L'Architecture et des Travaux Publics, no. 20 (1862). (Fotografía de Google Digitized. University of Michigan). la tradición de otros tratadistas franceses barrocos como Ch. A. d'Aviler, G. Boffrand o J. F. Blondel. ${ }^{18}$ En estas publicaciones se recogen las ilustraciones de modelos de palacios y repertorios ornamentales det estilo imperio que ha podido ser fuente de inspiración para determinados palacetes de La Habana. En el caso gallego sobresale el uso de las cubiertas de tipo mansarda en determinadas casas del entorno de Vilagarcía de Arousa. Siguiendo con la escuela francesa del siglo XIX, será Viollet-Le-Duc quien mantenga la línea definida por su antecesor, destacando entre su obra escrita el compendio formado por dos volúmenes y titulado Habitations Modernes, que ilustra una serie de casas contemporáneas, tomando como referencias modelos procedentes de diversos países europeos que bien sea por su composición tipológica, o bien por determinados elementos ornamentales, permiten hacer una comparación con determinadas casas indianas gallegas. Por ejemplo, en Casa de Versalles (Seine-et-Oise) presenta el mismo esquema tipológico organizado en torno a un cuerpo principal de habitaciones, al que se anexa una torre y un porche de entrada. ${ }^{19}$ En Galicia este esquema se aprecia en varias localidades de las provincias. La Casa del Arenal (Cabanas, 1930), Casa en Gaxate (A Lama, principios s. XX), Villa Aurora (Fornelos de Montes, 1930), Casa dos Enanos (Ribadeo), Casa do Fondón, Casa García (Chao de Ourol, 1930) o Casa de Serafín Flores Sobrino (A Guarda, 1930), dan buena muestra de ello. ${ }^{20}$ El Centro Cultural de A Guarda constituye otro prototipo de casa que ofrece una manera

16. La revista se publicó anualmente entre 1840 y 1888

17. Cesare Daly, L'Architecture Privée. Nouvelles Maisons de Paris et des Environs, 2 vols. (París: Ducheur et Cie, 1872).

18. Algunas de estas obras: Augustin Charles de Aviler, Cours d'architecture qui comprend les ordres de Vignole, avec des commentaires, les figures \& les descriptions de ses plus beaux bâtimens, \& de ceux de Michel-Ange: plusierus nouveaux desseins \& tout ce qui regarde l'art de bâtir: avec une ample explication par ordre alphabetique de tous les termes; premier partie (París: Nicolas Langlois, 1691); Germain Boffrand, Livre d'architecture: contenant les principes generaux de cet art et les plans, elevations et profils de quelques-uns des batimens faits en France \& dans les pays etrangers (París: Guillaume Cavelier, 1745); Jacques François Blondel, Architecture Françoise ou Recueil des plans, elevations, coupes et profils des Eglises, Maisons Royales, Palais, Hôtels \& Edifices les plus considérables de Paris, ainsi que des Châteaux \& Maisons de plaisance situés aux environs decette Ville, ou en d'autres endroits de la France, bâtis par les plus célébres Architectes, \& mesurés exactement sur les lieux...Avec la desciption de ces Edifices, \& des Dissertations utiles \& intéressantes sur chaque espèce de Bâtiment, 4 vols. (París: Charles-Antoine Jombert, 1752-1754).

19. Eugene Viollet-le-Duc, Habitations Modernes (París: A. Morel et Cie., 1877), plancha 1.

20. Este formato también ha sido uno de los preferidos en la construcción asturiana y así se aprecia en La Villa Encanto en Villaviciosa o algunas otras casas localizadas en el municipio de Cangas de Onís. 
diferente de integrar la torre en el edificio. ${ }^{21}$ Lo hace de manera similar a la Torre de los Moreno, a Casa de la Calzada (1910), o Villa Isabel y de la misma manera que en Villa El Pilar en Vigo (1913). ${ }^{22}$ Se trata de una composición que otorga al conjunto ciertas notas de pintoresquismo. La lámina que ilustra la Villa de Passy (París), integra el elemento vertical con un remate conopial, que incluso podría recordar a las fantasiosas arquitecturas palaciegas promovidas por el rey Luis II de Baviera. ${ }^{23}$ Otras imágenes, como la del hotel privado de París, ${ }^{24}$ acercan a planteamientos con esquema en forma de U, típicos de la arquitectura palaciega barroca francesa, parecidos a los de Casa de Laurentino (Moscoso. Pazos de Borbén, 1927) o en Casa de Domingo Domínguez y Casa de las Torres (Camposancos, 1920), aunque en este último caso los extremos laterales se ven enfatizados por el elemento vertical. Un esquema similar lo presenta Villa Lola (Os Vilares, Ourol), con cierto parecido a alguna de aquellas ilustraciones que en la obra de Le-Duc identifican casas holandesas, alemanas y danesas, destacando la Casa de Dornach. ${ }^{25}$ En Asturias, Villa Rosita (Navia), Villa Cristina y Villa Rosario (Luarca) podrían ser consideradas buenos ejemplos de este tipo. Por ofrecer un esquema diferente, las imágenes que ilustran las mansiones de Holgate (Fig. 1) o la de Palaiseau presentan un prototipo en el que el remate calado de armazón que refuerza el frontón superior del cuerpo, cabría ponerlas en relación con determinadas casas gallegas como la Casa de Pita (Ourol, 1920), Casa de la Campana (Ponte Caldelas, 1915) o Villa Lola. Además, introducen un tipo de fachada marcada por las vertientes del tejado a varias aguas, que se ve enfatizado por la altura y proyección en planta del cuerpo central. Este último recurso de avance de la fachada en su parte central ha sido empleado con diferentes fórmulas en las casas de la costa lucense: Place Margarita (A Devesa. Ribadeo, 1926), Casa de Neira (Barreiros, 1911), Villa Modesta (Foz, 1911), Villa Miguelito (Lourenzá, 1925) o Villa María (Magazos. Viveiro, 1920), y en la provincia de Pontevedra, Villa Pilar (Pontevedra, 1905) o la Casa de Manuel Alonso Sobrino (A Guarda, 1928).

Frente a los esquemas desarrollados en Europa, en el continente americano la obra escrita de J. A. Downing recoge una serie de repertorios de casas de campo que ilustran ciertos aspectos de la construcción al otro lado del océano Atlántico. Estos libros, publicados en las décadas de 1840 y 1850, son coetáneos a la obra de Daly, antecediendo inmediatamente a la Escuela de Chicago y a la obra de Wright. En The Architecture of Country Houses se establece una diferenciación entre la casa de campo, la casa-granja y lo que es considerado como una villa. ${ }^{26}$ Se definen los rasgos que caracterizan a cada uno de ellos, sus dimensiones, diseños, los materiales recomendables para su construcción, destacando el uso de la madera, ladrillo, piedra, pero también se introducen elementos como el cemento o el estuco... Aparecen aquí ilustradas casas de campo de única planta, con bajocubierta pronunciada, grandes chimeneas y varios porches, en los que sobresale un elemento típicamente americano como es la bay-window (bow-window) que se introducirá en algunas casas gallegas y también será reinterpretado bajo diferentes propuestas formales. La manera en la que se representan, solo comprensible desde la perspectiva de un arquitecto paisajista del siglo XIX, ${ }^{27}$ aporta unas visiones del lugar que bien podrían recordar cualquier escenario ilustrado por J. Constable. Al detenerse en el análisis de cualquiera de estos modelos rodeados de bosques o jardines, resulta inevitable no pensar en Villa Ene-

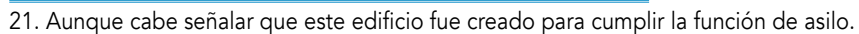

22. Sobre este edificio: José Segarra Prado, "A propósito de "Villa Pilar" una aproximación al "cotage" suizo," El Museo de Pontevedra, no. 41 (1987): 309-53. En Asturias, Villa Concepción en Somió, Villa Rosario en Ribadesella o Villa las Baragañas en Villaviciosa. Para profundizar en el caso asturiano: María Cruz Morales Saro, Arte, cultura y sociedad en la emigración española a América (Oviedo: Servicio de Publicaciones de la Universidad de Oviedo, 1992).

23. Viollet-le-Duc, Habitations Modernes, plancha 80.

24. Viollet-le-Duc, plancha 8.

25. Viollet-le-Duc, plancha 75.

26. Andrew Jackson Downing, The Architecture of Country Houses, including designs for cottages, farm-houses, and villas (New York: D. Appleton \& Co., 1851).

27. Modelo de casa número 3, Downing, 83.
} 


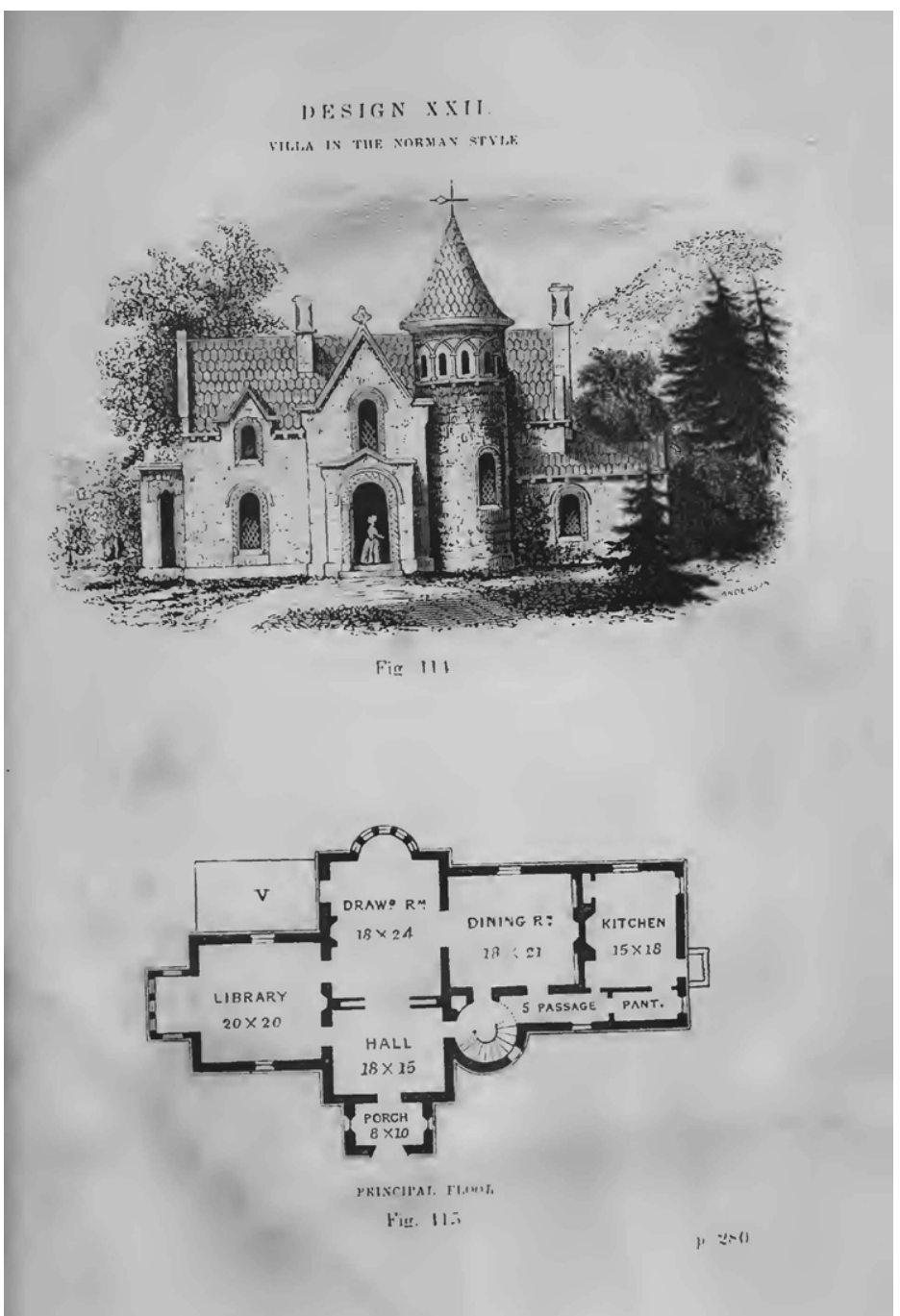

Fig. 3. Casa de campo. A. Jackson Downing, The Architecture of Country Houses, including designs for cottages, farm-houses, and villas. New York: D. Appleton \& Co., 1851. (Fotografía de Archieve.org). dina o la colindante al Chalet de O Seixo (1924), comprendidas como si se tratara de cabañas alpinas, aún cuando sus parámetros decorativos varíen. En la presentación de estas casas de campo americanas es habitual el uso de buhardillas, cresterías caladas en madera que perfilan el perímetro de las cubiertas (verge-boards), y que se conjugan con barandillas y cierres de vanos, los cuales a veces se diseñan como espacios reservados para la lectura o para la conversación, rodeados de ventanas. ${ }^{28}$

A partir de estos esquemas básicos, las composiciones se van alterando y alternando en forma, número de plantas y empleo de elementos. Poco después, el autor se detiene en el tratamiento de las villas, presentando modelos diferentes, por lo general extraídos de la tradición europea. Es el caso de la descripción que hace de la Villa de Estilo Normando, ${ }^{29}$ que introduce el elemento turriforme de planta circular en la propia fachada, desequilibrándola, como así había sucedido en la arquitectura normanda medieval, y también en ciertas construcciones inglesas de la misma época ${ }^{30}$ (Fig. 3). La torre se convierte en el elemento estructural que encierra la escalera que comunica los diferentes niveles. En la Torre de los Moreno o en la Casa de la Calzada de Ribadeo (1910) se puede localizar dos ejemplos de este diseño. Frente a este uso oculto de la escalera, común en la construcción medieval, se presentan otra serie de villas antecedidas en fachada por una escalinata en la que el uso de la barandilla mantiene la continuidad con las terrazas y azoteas que se abren en diferentes direcciones. Este esquema que tiene sus primeros exponentes en las villas italianas y en determinados châteaux franceses renacentistas, se repetirá en no pocos palacios barrocos y se mantendrá en algunas casas de indianos en Galicia, con desarrollos discretos como sucede en Villa Amalia o Villa Julia

28. El modelo de casa número 5, descrita como casa con porche de estilo inglés ilustraría este tipo. Downing, 100

29. Modelo de casa número 22, Downing, 280.

30. Elemento torreado que cobrará especial relevancia con el revival neolombardo producido por las ediciones de Fernand de Dartein, Étude sur l'architecture lombarde et sur les origines de l'architecture romano-byzantine (París, Dunod, 1865); Fernand de Dartein, Architecture lombarde (París, Dujardin et Cie, 1892); así como de Edoardo A. Mella, Elementi di architettura lombarda redatti da Edoardo Mella (Torino, Fratelli Bocca,1885), que encontrarán su correspondencia más directa en algunas villas sintrenses de época. Véase al caso la Villa Sassetti proyectada por Luigi Manini. Iván Moure Pazos, "Un trozo de Italia en el corazón de Sintra: la obra de Luigi Manini para Victor Carlos Sassetti en el Monte da Lua," Laboratorio de Arte: Revista del Departamento de Historia del Arte, no. 29 (2017): 636-52. 
(San Miguel de Reinante. Barreiros, 1926), y otros con un mayor empaque como Villa Honorata (Gaxate, A Lama, 1929) o Villa Lola.

La primera de estas dos, Villa Honorata, ${ }^{31}$ presenta un esquema similar al de Villa Libunca (Narón, 1918), Casa García, Casa dos Enanos o El Fondón y que se debe poner en relación con lo que Downing reconoce como la villa de estilo italiano, ${ }^{32}$ en la que la fachada se caracteriza por presentar un gran número de oquedades, ventanas pluriformes, puertas y especialmente las logias. Además, destacando en planta y alzado, sobresale una gran torre de formato rectilíneo, ${ }^{33}$ que también cabe relacionarlo con los diseños renacentistas italianos.

Hasta aquí bien se podría afirmar que desde el punto de vista tipológico la casa indiana gallega apenas ofrece novedades respecto a otros ejemplos de casas típicas del siglo XIX, de diferente promoción. Las formulaciones compositivas, de una u otra manera, eran comunes. Volviendo al inicio, desde esta perspectiva, la Casa Winslow de Wright tampoco se saldría de estos parámetros. Solo a partir de la combinación de las tipologías y de sus múltiples variantes, en unión con el elemento ornamental y al entorno específico en el que se encuentran estas casas, es como se entiende la peculiaridad de la casa indiana gallega.

\section{En vertical y horizontal. Elementos decorativos para la casa indiana gallega} La casa indiana gallega presenta peculiaridades concernientes al territorio en el que se asienta, su configuración tipológica y el repertorio ornamental que desarrolla y que varía a lo largo de las décadas.

Lo primero que se debería resaltar es la dispersión territorial, que abarca desde núcleos poblacionales costeros de cierta relevancia (Viveiro, Ares, A Guarda y Pontedeume) hasta pequeñas aldeas situadas en las entrañas de los montes gallegos (Ourol, Fornelos de Montes, Gaxate-A Lama, Brión-A Coruña, Ponte Caldelas, Pazos de Borbén y Mondoñedo), aspecto que identifica las diferentes procedencias de los emigrados. ${ }^{34}$ Ello produce una situación anómala porque se trata de una arquitectura descontextualizada respecto al resto de pequeñas y humildes viviendas tradicionales que rodean la casa indiana, pero que a su vez otorgan al entorno una singularidad única. En otras ocasiones se trata de ciudades de rango, como Ferrol o Vigo. Este hecho determinará que haya un mayor número de viviendas adosadas en núcleos urbanos como Ribadeo o A Guarda, mientras que la vivienda independiente resulta frecuente en zonas rurales. En la ciudad, existen excepciones como Villa Pilar, Casa Canido, Casa del Óptico, Casa de Benito Galcerán o la desaparecida Casa de dońa Águeda (Betanzos). Y a la inversa, casas adosadas en aldeas, tales como Casa Rico, Villa Lorenza o Casa de Paco Bello. En un punto intermedio podrían encasillarse la de Juan Naveira en Betanzos, la Torre de los Moreno y Casa de Clemente en Ribadeo. ${ }^{35}$

31. Carlos Rodríguez Dacal, "O mundo verde de Villa Honorata, casa indiana modélica lamesa," A Pedreira: revista cultural e turística do Concello da Lama, no. 10 (2012): 13-33.

32. Modelos de casa número 23 y 25. Downing, The Architecture of Country, 285, 317.

33. Algunos autores ven una posible influencia o préstamo de la arquitectura regional cántabra en la arquitectura de promoción indiana gallega. Iglesias Veiga Arquitectura e indianos na cidade de Vigo e Bisbarra, 17-18.

34. En Galicia todavía restan por localizar, inventariar y localizar casas en otros puntos geográficos donde el fenómeno migratorio ha tenido notable repercusión. Garrido Moreno, "A imaxe arquitectónica dos indianos galegos," 330.

35. Cabe indicar en este punto, que el entorno inmediato de estas casas, especialmente en los núcleos urbanos, en ocasiones ha experimentado alteraciones, que han dañado y deteriorado la imagen inicial de estas casas, y desarticulado su armonía. En consecuencia, actualmente se ofrece una visión absolutamente descontextualizada respecto al momento en que fueron construidas, teniendo que recurrir en el mejor de los casos a fuentes fotográficas. Como ejemplo de 
Ligado a lo anteriormente expuesto se plantea la cuestión sobre el origen de estas construcciones. Y en este sentido, se comprueba que lo habitual es que las casas independientes (especialmente chalets, villas) se construyan desde sus cimientos como obras nuevas, y solo en ocasiones se encargue el proyecto a arquitectos titulados. En la mayor parte de las ocasiones serán maestros de obras cualificados quienes dirijan las obras, siguiendo modelos que ocasionalmente podían aportar los propios promotores. ${ }^{36}$ Por otro lado, y quizá en un número mayor, la práctica más común consistía en realizar pequeños ańadidos a la casa familiar, intentando adaptar a esta estructura tradicional de formato rectangular y cubierta de doble agua nuevos componentes como galerías, buhardillas, miradores o terrazas y balcones, en algunos casos adornados con molduras decorativas.

Una comparativa con el caso homólogo asturiano permitiría afirmar que el legado arquitectónico de los indianos gallegos, salvo determinadas excepciones, se caracteriza por una mayor sobriedad en el desarrollo de tipologías, ${ }^{37}$ aunque a lo largo del rastreo realizado se haya podido comprobar que existen dos grupos bien diferenciados. Casas como las de Barracido, hermanos Blanco, Casa América, Carelle, Barreiro, Manuel Piñeiro, Casa Grande, La Primitiva, Carballido o el Señorón, responden a un planteamiento de fachada regular, simétrica, que puede ser considerado como el más habitual. Por ello las villas Rosa, Frayán, Adriano, Canido, Isabel, Fondón, Julia o Casa de la Calzada, son ejemplos menos habituales y poseedores de una mayor singularidad, que a su vez los convierte en un reclamo visual. Bien se trate de tipologías más o menos originales, son todas estas construcciones que se desarrollan en una, dos o tres plantas (excepcionalmente cuatro como en Casa Bonín en Vigo). La Casa Verde de Ponte Caldelas, así como la Casa de Gerardo Fernández Troncoso en Goián-Tomińo, ejemplifican el modelo de vivienda de una planta con bajocubierta, mientras que Villa Borinquen o Villa Aurora añaden a ese mismo esquema una torre.

La misma situación se produce en las casas con dos niveles. Se trata del grupo más numeroso que parte de una estructura inicial de planta rectangular tradicional gallega, cubierta con techumbre de vertientes o mansarda. Se reparten a lo largo del territorio gallego, con ejemplos destacados en la península de Bezoucos como son las casas de Concha Amado (Redes) o Villa Frayán (Cabanas); Casa de Nelle (Narón) en la Costa Ártabra; en el interior de la provincia de Pontevedra las casas de la Campana o de Raquel (Ponte Caldelas), Casa de Lino y Casa de Garrido (Anceu. Ponte Caldelas); en la zona del Baixo Miño Casa de Juan Troncoso, Casa dos Baqueiro, Villa Domínguez o Villa Estrella; y en la Marińa Lucense las casas de Pita, Mesón, Seńorón o Villa Lola. A este grupo cabe añadir aquel que incorpora una torre, como sucede en Casa del Arenal, en Villa El Fondón, Villa Rosa, la actual Casa da Cultura de Narón, Casa de las Torres, Torre-Maseda y algunas otras ya descritas con anterioridad; y también una derivación del primero que sustituye el uso de cubierta de aguas por la azotea, caso de Villa Adriano.

Menos habituales son las casas de tres niveles. Por ello, las villas Adela (Vilaronte, Foz) y Pilar (Pontevedra), Casa de Clemente en Ribadeo, así como la del Óptico en la misma ciudad, se convierten en

esta situación está la Casa Rosa de Pontedeume, numerosos ejemplos en Villagarcía, donde además una gran parte de su patrimonio de indianos está en alto riesgo de desaparición, la demolida casa Pernas en Viveiro o Casa Canido.

36. Garrido Moreno, "A imaxe arquitectónica dos indianos galegos," 328; Algo similar sucede en Asturias: Álvarez Quintana, "La casa indiana," 48.

37. A pesar de que se han realizado catálogos de arquitectura doméstica indiana, cierto es que todavía falta por rastrear de una manera más localizada y detallada otros puntos gallegos en los que también tuvo fuerte repercusión el fenómeno de la emigración. Bores Gamundi, Casas de Indianos; Fernando Bores Gamundi, Casas de Indianos. Pontevedra (Santiago de Compostela: Xunta de Galicia, 2009). En la provincia de Pontevedra destacan trabajos como los de Teresa Táboas, Emigración e Arquitectura "Os Brasileiros" (Pontevedra: Deputación de Pontevedra, 1998); Mercedes Martínez Plasencia y Teresa Sánchez Cora, Ponte Caldelas. Memoria escrita dun pobo (1500-1936), vol. 4. (Ponte Caldelas: Deputación de Pontevedra, 2004). Para el presente trabajo, se han tomado como fuentes principales todos estos trabajos. Urge realizar un catálogo de la provincia de Ourense, y profundizar en el estudio de las zonas de la Península del Barbanza, y de la Costa da Morte. 


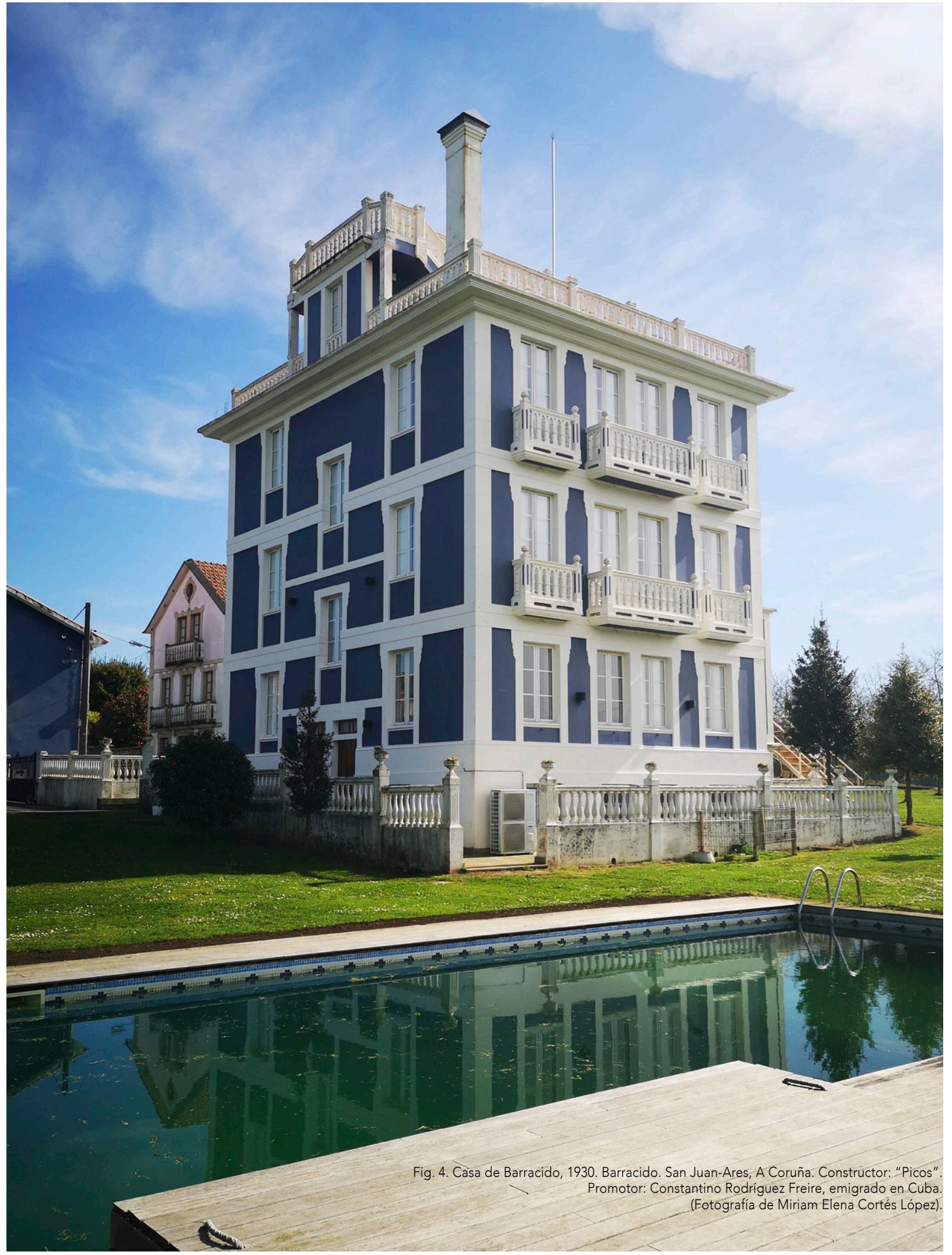


ejemplos únicos, lo mismo que sucede en el lugar de Barracido (Ares), donde la gran casa conocida como La Minerva utiliza la azotea como sistema de cubierta. Fuera de los parámetros habituales habría que destacar Casa de Soutelo, en Forcarei, que destaca no solo por sus dimensiones sino por la serie de elementos ornamentales que rodean sus cuatro fachadas.

Una vez que se han definido las bases sobre las que se asienta la arquitectura de indianos en Galicia, interesa definir ciertas notas recurrentes que hacen destacar a estos edificios. Se trata de una serie de recursos decorativos, que desarrollan un vocabulario procedente de varios estilos, lo que procura nuevamente una diversidad de modelos y singularidad en los exteriores. Este hecho es una constante en todo el territorio gallego, y quizá lo primero que haya que subrayar es que no existe una pauta que identifique la construcción gallega con el lugar americano en el que su promotor hizo fortuna. Cierto que nombres como Villa Borinquen o Villa Argentina aluden a referencias topográficas, pero no necesariamente fueron copias de arquitecturas tradicionales americanas. Lejos de ello, y salvo contadas excepciones, los repertorios decorativos responden más bien a modelos europeos, inicialmente exportados a América y luego devueltos a Europa. De esta manera, lo que sí se puede definir es que dependiendo del vocabulario estilístico que se desarrolla en las fachadas, se pueden matizar cronologías y gustos personales (bien sea de autor o de promotor). Los estilos más empleados pasan por las fórmulas historicistas, aunque más llamativos pueden resultar aquellos casos que se valen del lenguaje modernista y Art Decó, si bien la tendencia habitual es la del eclecticismo.

Por otro lado, también cabe matizar que existe una minoría de casas en las que la presencia de elementos decorativos es prácticamente inexistente o se reduce a pequeñas notas que incluso más que decorativas se deberían considerar estructurales. Villa Argentina es una buena muestra de ello, al igual que Villa Primitiva, que apenas emplea recursos de esta índole, más allá de la peineta superior que sirve de soporte para el nombre. Un poco más de gracia decorativa aporta Casa de Barracido, a través del uso de barandillas en balcones y azoteas (Fig. 4); las galerías y vanos de Casa Canido; o las molduras de escayola con motivos florales que se intercalan en la fachada de Villa Rosa en Cabanas.

En el lado opuesto está otra serie de casas en las que la decoración se potencia de tal manera que acaba por otorgar al conjunto el carácter singular que caracteriza a la arquitectura de indianos. Elementos estructurales que se convierten en marco ornamental, tales como escaleras, vanos y en relación con estos, balcones, azoteas, así como la introducción de las galerías y las bay-window. También las puertas se convierten en superficies de extraordinario interés para ser decorados. Los cierres definen el perímetro límite de la propiedad y limitan los curiosos jardines donde destacan las palmeras y los camelios, integrándose estanques, bancos, cenadores, pajareras, incluso albercas y otras dependencias novedosas como las cocheras o capillas. En algunas ocasiones, las torres se convierten en un espacio reservado para decorar, al igual que sucede con las chimeneas, y se introducen nuevos elementos como puentes, cúpulas o bóvedas con función de miradores, y también buhardillas en la parte superior, de la misma manera que se incluyen sótanos en la base de la casa, que visualmente se convierten en peanas.

En lo concerniente a los elementos decorativos más destacados, lo primero que se debe hacer notar es la introducción de materiales que facilitarán nuevas fórmulas de trabajo. ${ }^{38}$ En este sentido se podrían citar

38. Garrido Moreno, "A imaxe arquitectónica dos indianos galegos," 330. 


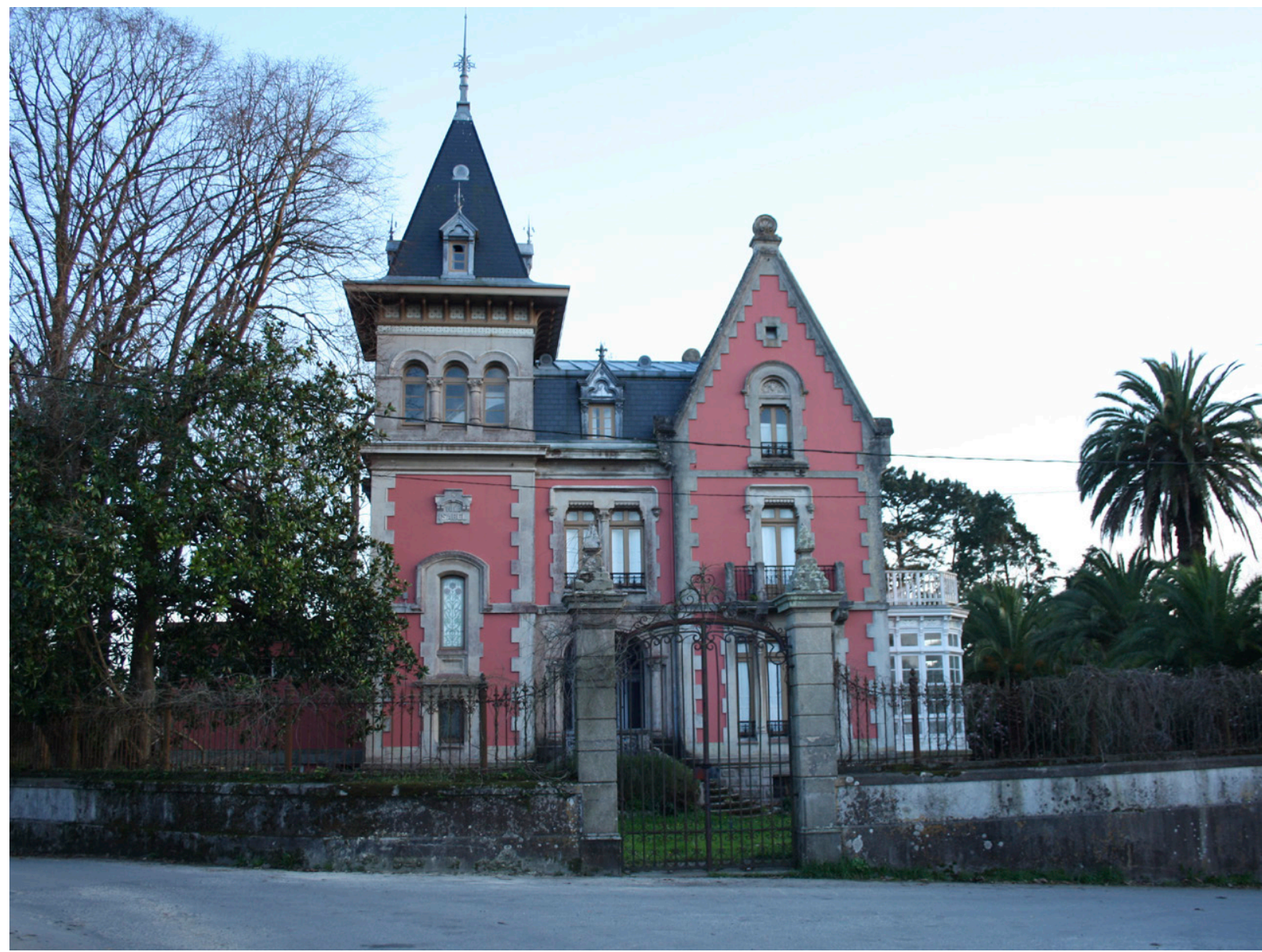

Fig. 5. Villa Isabel, 1899. O Vilar. San Pedro de Nós-Oleiros, A Coruña. Arquitecto: Luis Bellido González. (Fotografía de Miriam Elena Cortés López).

las molduras producidas en serie con motivos decorativos florales, las barandillas de hormigón y de forja para los balcones, o el uso del hierro, el hormigón y madera para la ejecución de las galerías. Es frecuente el uso de cresterías, peinetas, policromías que han variado con los años, empleo de revoques cerámicos, y el uso de acróteros y esculturas que se suelen emplear en el circuito de las barandillas. Y quizá uno de los elementos más característicos de estas casas sea la rotulación que incluye el nombre o la fecha de construcción de la vivienda.

Comenzando por el primero de estos elementos, la escalera es un elemento funcional pero que al ubicarse en el exterior del edificio, condiciona, define y decora la fachada del mismo. Existen varias formas de situarlas y de desarrollarlas. ${ }^{39}$ Desde la Edad Moderna ocupa una posición preferente, siendo el elemento de unión entre el nivel inferior y el piso noble de las casas, aunque en la arquitectura popular es frecuente su

39. Una aproximación al estudio de la escalera en el marco de la arquitectura de indianos, Miriam Elena Cortés López, "Escalera en la arquitectura indiana gallega. Pervivencia y tradición en las obras de los hermanos García Naveira," Norba. Revista de Arte, no. 31 (2018): 9-29. 

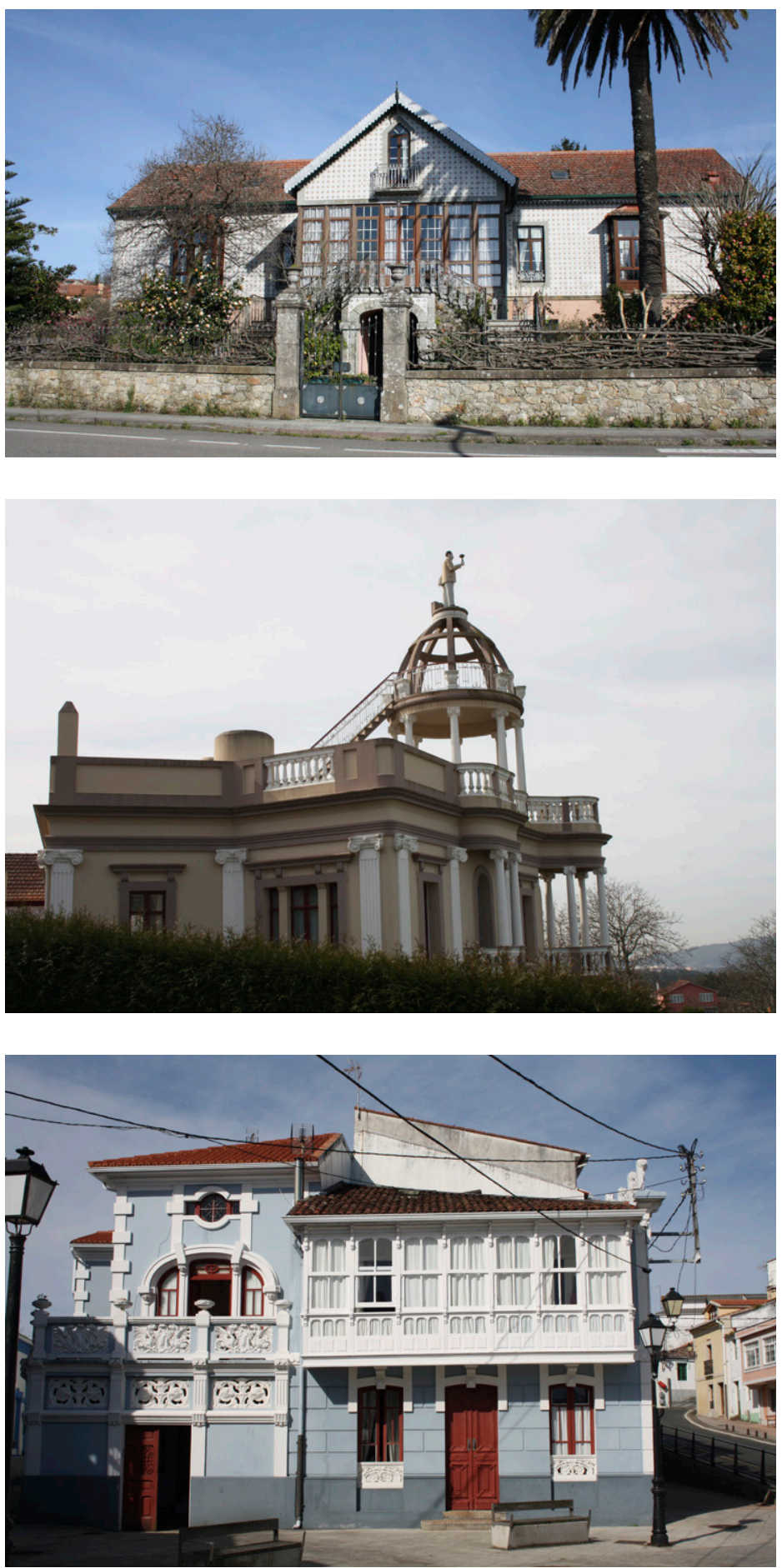

ubicación en fachadas laterales (por ejemplo las casas de patín), siguiendo fórmulas menos ostentosas. La casa indiana copia estos modelos, siendo frecuente que en las villas más llamativas se utilice la escalera frontal. Villa Honorata, Villa Isabel, Villa Aurora o Casa de Gerardo Fernández Troncoso desarrollan un planteamiento de estilo palaciego, con discursos complejos y balaustres realizados en piedra u hormigón, y que integran elementos decorativos como esculturas, acróteros, fuentes e incluso revoques de azulejos (Fig. 5). Un caso similar lo aporta Casa do Almacén (San Miguel de Tabagón, El Rosal), en este caso empleando una forja decorada como balaustrada y sustituyendo el estanque central por un gran vano que facilita el acceso a la planta baja del edificio (Fig. 6). Otras villas como Julia, Arenal, Rosa, Libunca o Margarita Place, unen la escalera al porche de acceso, recurso mediante el cual se enfatiza la entrada principal. También puede suceder que la escalera se desplace a uno de los laterales de la fachada principal, como en Villa Lola o en Casa de Raquel (Ponte Caldelas). Existen otras maneras de disponerlas. Por ejemplo, el acceso principal de Villa del Adriano se realiza por la cota elevada de la colina, lo que provoca que la escalera se sitúe en la parte baja que une con el jardín. Lo mismo sucede en Casa de Rodríguez (Ponte Caldelas). La casa de Fene ejemplifica un uso de la escalera menos habitual como es la comunicación en la azotea con la parte superior de la cúpula calada coronada por la gran escultura del Adriano (Fig. 7). Este

Arriba Fig. 6. Casa do Almacén, ¿1905?. San Miguel de Tabagón. O Rosal, Pontevedra. Constructor: "Brage". Elementos decorativos: Domingo Pires y Domingo Viana. Promotor: José María Blanco Gándara, emigrado en Brasil. (Fotografía de Miriam Elena Cortés López).

En medio Fig. 7. Casa del Adriano, 1921. Barallobre. Santiago de Barallobre-Fene, A Coruña. Arquitecto desconocido. Promotor: Antonio Fernández Fernández, emigrado en Cuba. (Fotografía de Miriam Elena Cortés López).

Abajo Fig. 8. Casa de Concha Amado, 1915. Redes. Camouco-Ares, A Coruña. Constructor: "Brage". Elementos decorativos: Domingo Pires y Domingo Viana. Promotor: José López Martínez, emigrado en Cuba. (Fotografía de Miriam Elena Cortés López). 
mismo recurso, vinculado a la función de los miradores (elemento característico de esta arquitectura), se localiza también en Casa de Barracido.

Los miradores, con su diversidad de fórmulas (abiertos, cerrados, circulares, rectangulares, abuhardillados), forman parte del grupo de vanos con los que se perforan las fachadas y cuya función fundamentalmente consiste en iluminar, ventilar, visionar y permitir el acceso. Las casas indianas aportan diversidad formal, con remates mixtilíneos, uso de parapetos, quitapolvos con molduras policromadas, de las que son buen ejemplo las casas de Redes. En Villa Amalia sorprenden los ventanucos superiores ovales que se corresponde con la bajocubierta, lo mismo que las molduras que enmarcan las ventanas y que se sostienen mediante pilastrillas, que se sustituyen en el eje central por las columnillas. En Casa de Concha Amado, los parapetos realizados en hormigón, introducen en la práctica común de la seriación, y su original motivo decorativo parece extraído de un bestiario medieval, incluso recordando a ciertos modelos desarrollados en los parapetos de la escalera del castillo de Blois en Francia (Fig. 8). El uso de placas decorativas en el perímetro de la ventana fue también una práctica habitual y repetida en ciertas casas de la Marińa Lucense. Cabe destacar el empleo de un motivo ornamental como es el mascarón femenino que corona las molduras superiores de las ventanas de Casa de don Inocencio (Ribadeo) pues es el mismo que se identifica en las casas de la Rúa San Roque no 16 de Ribadeo o en Casa Grande (San Cosme-Barreiros). Probablemente detrás de estas obras esté los mismos constructores y talleres. ${ }^{40}$

La decoración de paramentos murales define en buena medida los parámetros estilísticos que se adoptan en cada casa. En Redes se puede ver la influencia del Modernismo en la fachada de Casa de Paco Bello. En Ponte Caldelas sucede lo mismo en la Casa de Manuel Martínez. En ambas sobresale el empleo de molduras (en hormigón o escayola) decoradas con lazos, rosetas, palmetas, pequeñas piezas geométricas que desbordan y remarcan determinados puntos como los dinteles, cresterías y balcones, con movimientos ondulantes que dinamizan y adornan sobresalientemente la imagen exterior del edificio. Lo más habitual es que se empleen vocabularios eclécticos, como sucede en Villa Adela cuya decoración remite a modelos afrancesados, mediante el uso de guirnaldas que se intercalan con las fórmulas modernistas desarrolladas en los balcones laterales; o en la Torre de los Moreno, conjunto de grandes dimensiones que en sus tres fachadas integra elementos decorativos como columnillas, cenefas vegetales, mensulillas, guardapolvos con decoración frutal y acróteros, ejecutados en su mayor parte en hormigón y hierro.

En ocasiones, en las ventanas se combinan materiales como la madera y el vidrio, con tracerías y marqueterías que apuntan a determinados estilos como el Art Decó. Lo mismo sucede con las puertas principales o los cortavientos. Como ejemplo de este último se podría destacar el de Casa do Relámpago en A Guarda, en cuya parte superior se reproducen unas pequeñas ventanas con balcón. Por lo general, las puertas se realizan en madera, en ocasiones con pequeños añadidos de vidrio y forja, y lo habitual es que sus hojas se ornamenten con motivos florales o vegetales y molduras cajeadas que sirven de marco para la decoración. En las casas de Barreiro, La Campana, Manuel Pińeiro y La Cendona, todas ellas en el ayuntamiento de Ponte Caldelas - igual que sucede en las casas América y de Jesús Blanco en Brión- se puede apreciar la laboriosidad con la que fue ejecutado este elemento.

40. Garrido Moreno, "A imaxe arquitectónica dos indianos galegos, " 331 


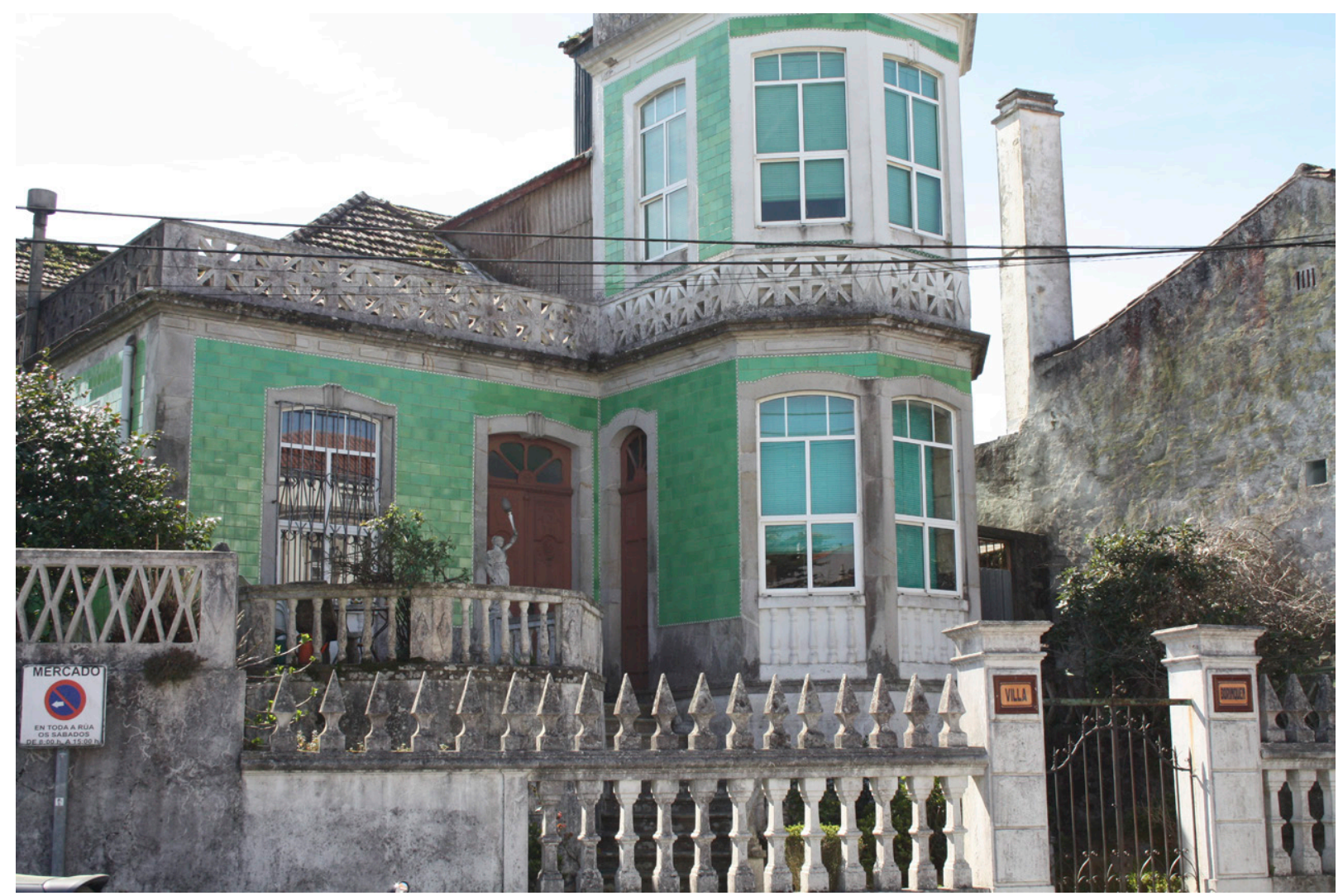

Fig. 9. Villa Borinquen, 1910. A Guarda, Pontevedra. Arquitecto: Antolín Silva. Promotor: Antonio Portela Silva, emigrado a Puerto Rico. (Fotografía de Miriam Elena Cortés López).

Dentro del ámbito de los vanos, cabría señalar dos elementos más. El primero de ellos podría ser considerado como una aportación americana. La bay-window o ventana mirador, con su peculiar forma semicircular o poligonal, es un elemento cuyo uso es excepcional, como en Villa Borinquen, ya que lo general en el caso gallego es que se reinterprete a la manera local, al ser asumido como si se tratara de una galería (Fig. 9). La solana o galería gallega es el típico elemento que el indiano suele ańadir a la casa matriz cuando la obra no es de nueva planta. La galería es una estructura habitacional que tradicionalmente se ejecuta en madera y vidrio, aunque en las casas indianas existen ciertas preferencias hacia su construcción en forja, como sucede en la casas de Daniel o de Manuel Pińeiro. El cristal que las rodea, igual que sucede con el de las ventanas, puede ser de colores, como en Casa Rico (Ortigueira) o La Cendona, dando una visión general más decorativista.

El uso de las galerías — cuya función primera consiste en proteger, acumulando el calor o resguardando del frío, haciendo energéticamente eficiente la vivienda $-{ }^{41}$ es frecuente en casi todas las casas de indianos, desarrollando varios modelos, ubicaciones y tamaños. Por ejemplo, existen casos en los que la galería ocupa el lugar reservado a balcones laterales en la fachada. La Casa do Atallo (Viveiro); las casas de Puentes, das Veigas y do Mesón (Ourol); o la de Juan Troncoso (Tomińo), quedarían incluidas en este primer grupo. Otra po-

41. Para un mayor análisis del uso y técnica de las galerías en Galicia vid. Antonio Garrido Moreno, "La Galería gallega: una tipología tradicional en permanente evolución," Anuario Brigantino, no. 21 (1998): 379-404. 
sibilidad es la que presenta la Casa Verde, dispuesta en el espacio central reservado al porche. Existe otra alternativa consistente en ubicar una gran galería en un lateral del edificio, caso de las villas Isabel, Amalia, Libunca, Frayán, Casa do Esguello (Viveiro), Casa de Pita y Villa Esteveri (Ourol) o Casa de Daniel (Pazos de Borbén). Casa Canido y la Torre de los Moreno integran varias galerías alrededor (Fig. 10). En cuanto a las formas, se podría destacar el caso de la Villa O Meu Repouso, ${ }^{42}$ donde estos elementos se diseñan con planta curvilínea y se ubican en los ángulos de la casa. Y finalmente también es común disponer una pequeña galería remarcando el eje central de la fachada e incluso elevarla a la parte superior de la cornisa, configurando una especie de mirador, sustituyendo a la típica ventana de buhardilla, como sucede en varias casas de Mariña: Villa Argentina, Casa de Neira, Villa Modesta o Casa de Carballo son algunos ejemplos.

Existen varias fórmulas para resaltar el eje principal de la fachada. Escaleras, porches, galerías, balcones... Pero con ellas conviven otros elementos como columnas, peinetas, torres o miradores. Todo ellos comparten como característica común la verticalidad. Villa Rosa, el

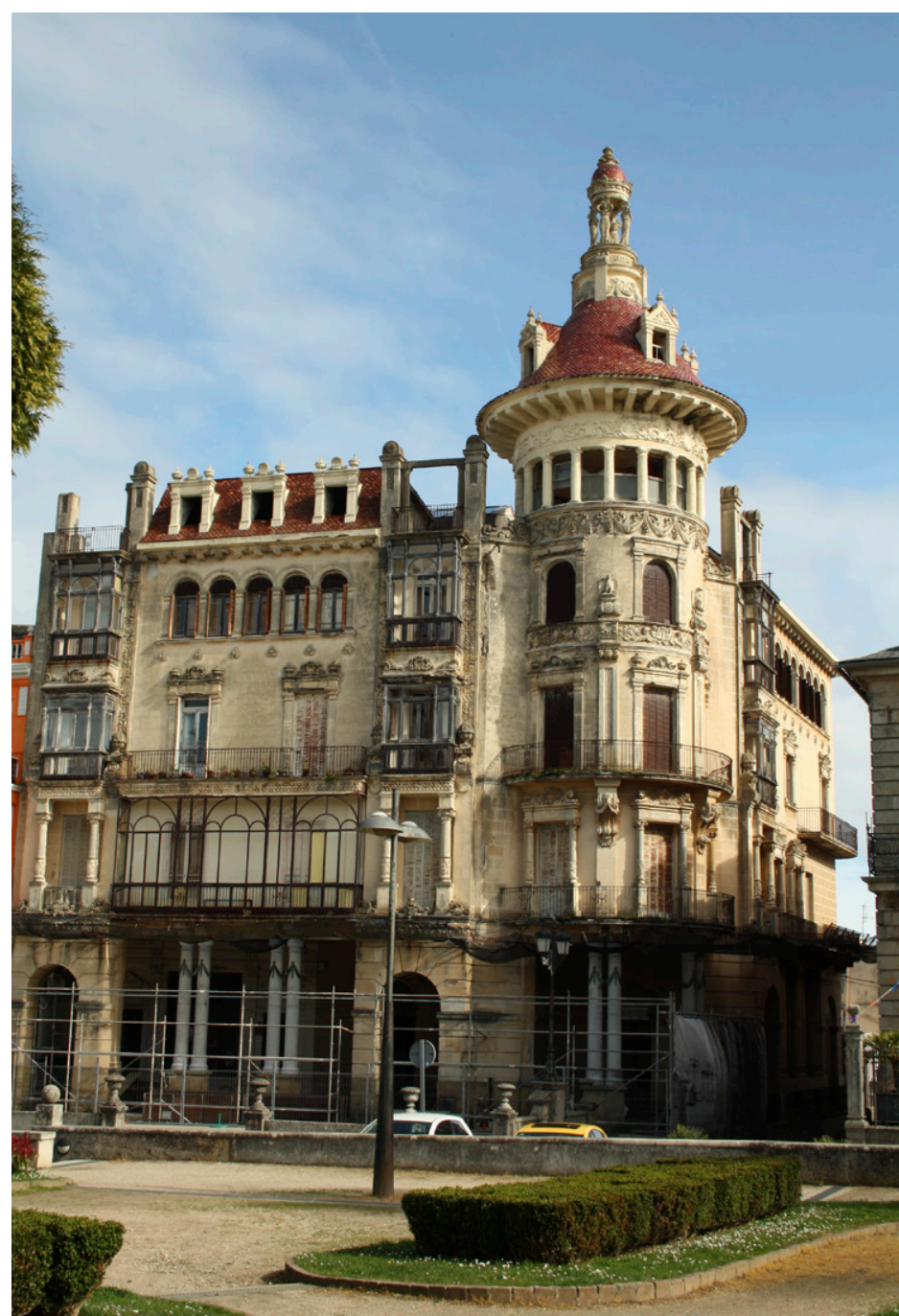

Fig. 10. Torre de los Moreno, 1912. Ribadeo, Lugo. Arquitecto: Julián García Núñez. Promotores: José María y Juan Moreno Ulloa, emigrados en Argentina. (Fotografía de Miriam Elena Cortés López).

Adriano, Casa de Rodríguez, La Cendona, la Torre de los Moreno, así como Casa de los Hermida (Ourol) o Casa de Gerardo Fernández Troncoso emplean las columnas (o pilares), en tanto que las peinetas son frecuentes en varias casas del foco lucense, igual que sucede con los miradores, en sus diferentes modalidades. En aquellos casos más exclusivos las torres se rematan en cúpula, como en Villa Julia o la Torre de los Moreno, a las que cabe añadir las casas de Fene y Ferrol. Junto a ello se localiza otro tipo de mirador situado en el centro de la cubierta de la casa: Casa Elena, Casa de Don Inocencio o Casa del Óptico en Ribadeo.

Siguiendo con la parte superior de la vivienda, cabría detenerse en el análisis de otros elementos. El primero de ellos es la azotea, poco habitual en la tradición constructiva gallega —no siendo así en la

42. Villa que recuerda en parte de su estructura y remate de la techumbre en cenefa al Chalet Biester de Sintra proyectado por José Luis Monteiro. Iván Moure Pazos, "Las villas de Luigi Manini en Sintra (1890-1912)," Ángulo Recto: Revista de estudios sobre la ciudad como espacio plural 6, no. 2, (2014): 103-6. 
tradición arquitectónica de otras destacadas ciudades portuarias españolas, como Cádiz- y en la que se ha querido ver uno de los préstamos de la arquitectura americana y de la que han hecho uso villas como la de Barracido, Adela o Villa Mosquera. ${ }^{43}$ En relación directa con este modelo de cubierta, se podría mencionar la introducción de las terrazas, como superficie a medio camino entre los balcones y las explanadas superiores. Casa de Concha Amado, Casa das Veigas y Casa do Esguello así como algunas del Baixo Miño introducen este elemento en algún punto de su desarrollo.

Otro elemento, con una función inicial de protección pero también soporte para la decoración, es la crestería superior que montada sobre la cornisa del edificio acota la azotea, y cuya traducción para las terrazas consiste en un parapeto, normalmente con forma de balaustrada que define el perímetro de la superficie. En lo que concierne a la parte superior es destacable el número de casas que recurren a esta solución, procedente en última instancia de modelos renacentistas italianos, que en ocasiones y siguiendo la tradición se compone de una serie de balaustres, rematados en su parte superior con una línea de acróteros, como sucede en Casa de Jesús Blanco, Casa de las Torres, Villa Modesta o Villa Adela. Como alternativa, a través de la aplicación de lenguajes artísticos diferentes, podría mencionarse Villa Lorenza, Casa de Carballido y Casa das Veigas.

En relación con los cierres, salvo concretas excepciones — que por norma general responden a criterios de ubicación en núcleos urbanos donde podría resultar complicado adquirir un terreno ex novo- lo habitual es que todas estas casas estén aisladas del entorno que las rodea. Paradójicamente están pensadas para ser expuestas públicamente, como así se puede apreciar en Casa de Benito Galcerán, en Villa Domínguez o su vecina Casa de Manuel Alonso Sobrino, lo mismo que en Casa Canido o Casa de las Torres. Sobre el tratamiento de los cierres de las fincas, también se podrían destacar varias cuestiones. La primera de ellas es la utilización de materiales como el hormigón, la piedra o la forja, siendo más común el uso combinado de estos materiales. Sobresalientes resultan las cercas de las casas de Lestedo, Villa Lola o El Cenador (Mondoñedo), con decoración en unos casos en clave de lenguajes historicistas, en tanto que en otros remiten a notas relacionadas con el vocabulario Art Decó. Los repertorios de vegetales entrelazados se combinan con piezas geométricas en los pilares de hormigón que rodean Villa Frayán, en tanto que las grandes puertas de forja que se integran en el perímetro de estos muros, ${ }^{44}$ repiten esquemas vegetales y en ocasiones incluyen una gran placa donde se recoge el nombre o la fecha de finalización de las casas. Las puertas de Villa Lola, Villa Amalia, Villa Rosa, Villa Honorata o Villa Julia son buenos ejemplos de ello. El año de construcción suele aparecer en diferentes puntos de la fachada, bien en las peinetas-o en un lateral de la pared.

En relación al enlucido de las superficies, aunque lo más habitual fue el uso de varias policromías que actúan con diferentes registros (uso de colores vibrantes en los lienzos planos y tonalidades más claras en los marcos que rodean vanos así como en barandillas, cresterías y peinetas), como se percibe en mayor medida en las provincias de Lugo y Coruña, es conveniente resaltar que en la provincia de Pontevedra muchas casas se revistieron con material cerámico policromado. El uso del azulejo como sistema de cobertura está

\footnotetext{
43. En relación a esta cuestión, cabría exponer la hipótesis de que América se hubiera convertido en un catalizador entre un modelo arquitectónico gaditano -la torre mirador, en sus diversas tipologías: de garita, de sillón, terraza o mixta-, exportado a las Indias, luego asumido en el desarrollo tipológico de la arquitectura de los países sudamericanos a los que en el siglo XIX migraron los gallegos. De esta manera el modelo de la ciudad andaluza podría haber llegado al territorio gallego a través de ese puente transoceánico. El desarrollo de la torre mirador gaditana se recoge en: Manuel Bustos Rodríguez, Cádiz en el sistema atlántico: la ciudad, sus comerciantes y la actividad (Cádiz: Sílex, 2005), 101-3; Juan Alonso de la Sierra, "Las Torres Miradores de Cádiz," en La conservación del Patrimonio Cultural en Cádiz y su provincia, ed. María Dolores Ruiz de Lacanal (Cádiz: Universidad de Cádiz, 2004), 59-79; María Dolores Ruiz de Lacanal Ruiz-Mateos, El patrimonio natural y cultural de Rota (Cádiz) y su conservación (Cádiz: Universidad de Cádiz, 2007), 36.

44. Algún ejemplo de este tipo de puertas en Cesare Daly, Revue Generale de L'Architecture et des Travaux Publics, no. 16 (1858), plancha 54.
} 
fuertemente enraizado en la tradición lusa y de hecho también ha sido empleado en las casas de brasileiros portuguesas, ${ }^{45}$ como Quinta Villa Beatriz en Santo Emiliao o Villa María en Paços de Ferreira. Se comprueba que en Galicia su uso es más frecuente en los municipios próximos al país vecino. Es posible que el empleo de este elemento se pueda relacionar con Brasil, que por otro lado fue uno de los lugares de destino preferidos por la población pontevedresa y durante mucho tiempo fue colonia portuguesa. La Casa de Juan Troncoso, la de Higinio Troncoso, Villa Borinquen, Villa Domínguez o la de Domingo Domínguez Sabariz emplean azulejos monocromos, en tanto que Villa Trinidad, Villa Estrella o la arruinada Casa de Valeriano Portela Rodríguez incluyen piezas con diseños vegetales y flores.

Como complemento decorativo para la casa indiana se diseñan jardines de diferentes tamaños, donde se identifica variedad de especies vegetales, muchas de ellas importadas de América, conviviendo con otros elementos artificiales creados para la comodidad de quien habita la casa. ${ }^{46}$ Junto a los bancos, estanques, espacios para el ocio y la distracción es frecuente la creación de un espacio reservado para el coche. Y en casos concretos como el de Casa de Gaxate, quizá en un intento por identificar la nueva casa de indianos con los pazos gallegos, también se construyeron pequeñas capillas.

\section{Conclusiones}

Como se viene afirmando desde hace décadas, la arquitectura de indianos no se debe asumir como una categoría estilística independiente que defina a un grupo concreto de casas y que respecto a otras de diferente promoción (fundamentalmente burguesa) marque diferencias notables. En el mejor de los casos, la arquitectura de indianos en Galicia se nutre de las diferentes corrientes artísticas de su tiempo, ejecutadas por los arquitectos más sobresalientes. De este modo, son numerosos los casos en los que se produce un restyling mediante el que solo se ańaden determinados elementos estructurales que mejoran la calidad de vida y ciertos elementos decorativos que en ocasiones distorsionan negativamente el aspecto inicial de la vivienda. Cuando se trata de edificios de nueva planta, la arquitectura de indianos en Galicia actúa bajo códigos similares a las correspondientes a otras comunidades vecinas, e incluso como colindante a Portugal, con el cual también comparte ciertos elementos comunes.

A través de los ciento cincuenta y dos casos que se han localizado — no todos están incluidos en este trabajo- se puede concluir que a pesar de la dispersión local (de norte a sur) hay esquemas similares en unas localidades y en otras, si bien es cierto que existen determinadas preferencias dependiendo de la zona. También se puede decir que el grueso de estas casas se encuentra preferentemente en las zonas costeras o próximas a ellas. No obstante, en Galicia todavía existen vacíos documentales sobre la cuestión, de tal manera que muchas casas de origen indiano todavía están fuera de control, lo que supone un riesgo para un patrimonio que, por otro lado, carece de cualquier tipo de protección, lo que en la mayor parte de los casos lleva a su irremediable desaparición, siendo objeto de abandonos, saqueos, posterior ruina y derribo. Un buen ejemplo de ello sería la Casa de doña Águeda, en el mismo centro de Betanzos, así como la Casa Pernas de Viveiro.

\footnotetext{
45. Al respecto: Maria Paula Brito Torres Peixoto de Aguiar, "Casas de "brasileiros" no norte de Portugal: do Porto à ruralidade" (tesis doctoral, Universidade de Santiago de Compostela, 2008)

46. La cuestión del elemento verde que rodea las casas de campo y villas también fue estudiada en la obra de Andrew Jackson Downing, A Treatise on the theory and practise of landscape gardening adapted to North America; with the improvement of country residences (New York \&London: Wiley and Putnam, 1844).
} 
De lo que no cabe duda es que se trata de casas singulares, que en la actualidad siguen siendo objeto de atención, como en su día lo habían sido para sus coetáneos. La cuestión radica en precisar si se puede hablar de gustos o preferencias estéticas del promotor, o si se trata de modelos bien conocidos por los arquitectos a través de las publicaciones periódicas o de los libros de recopilación de casas. Parece evidente que en este punto bien se podrían diferenciar edificios como los de los Moreno, Villa Fondón, Canido, Villa Isabel o Naveira, con un claro proyecto arquitectónico, respecto a otras como las del núcleo de Ourol o la aldea de Anceu (Ponte Caldelas), donde la mano del arquitecto parece inexistente. En el punto medio se encuentran grandes casas como la del Señorón, la del Almacén o Bella Vista, esta última un extraño conjunto que incluye de una manera un tanto discordante varios balcones, numerosas ventanas y una gran torre horadada donde se integra un reloj. En una situación similar, aunque con mayor armonía, se localiza Villa del Adriano, que quizá pueda ser considerada en firme como uno de los casos donde es el promotor quien da las pautas.

En base a lo dicho anteriormente también se debe anular la vieja creencia por la cual se pensaba que lo habitual era que el promotor de la obra tomara como referencia o copiara modelos concretos del país al que emigró. Puede ser que en algún caso esto sucediera, y que incluso tomara prestados ciertos elementos propios de la casa americana. Pero esto son excepciones.

Por otro lado, cabe matizar la importancia que para el estudio de la arquitectura de indianos puede tener el documento gráfico, ya que muchas de estas casas, especialmente aquellas que están en núcleos urbanos, han experimentado drásticos cambios que distorsionan la imagen real que en su día tuvieron. Ferrol, Villagarcía, Viveiro, Vigo o A Guarda son la mejor muestra de ello.

\section{Referencias}

Agrasar Quiroga, Fernando, y Alfredo Vigo Trasancos. Rodolfo Ucha Piñeiro: construindo Ferrol. Ferrol: Concello de Ferrol, 2014.

Alonso de la Sierra, Juan. “Las Torres Miradores de Cádiz.” En La conservación del Patrimonio Cultural en Cádiz y su provincia, editado por María Dolores Ruiz de Lacanal, 59-79. Cádiz: Universidad de Cádiz, 2004.

Alonso de Rocha, Aurora. "Los hermanos García Naveira, indianos: nota-homenaje." Anuario Brigantino, no. 39 (2016): 343-82.

Álvarez Quintana, Covadonga. "La casa indiana.” Obradoiro, no. 10 (1984): 45-51.

---. Indianos y arquitectura en Asturias: (1870-1930). Gijón: COAATA, 1991.

Boffrand, Germain. Livre d'architecture: contenant les principes generaux de cet art et les plans, elevations et profils de quelques-uns des batimens faits en France \& dans les pays etrangers. París: Guillaume Cavelier, 1745.

Bores Gamundi, Fernando, ed. Casas de Indianos. Santiago de Compostela: Xunta de Galicia, 2000.

---. ed. Casas de Indianos. Pontevedra. Santiago de Compostela: Xunta de Galicia, 2009.

Brito Torres Peixoto de Aguiar, Maria Paula. "Casas de "brasileiros" no norte de Portugal: do Porto à ruralidade." Tesis doctoral, Universidade de Santiago de Compostela, 2008.

Brooks Pfeiffer, Bruce. F. L. Wright. 1867-1959. Construir para la democracia. Köln: Taschen, 2004.

Bustos Rodríguez, Manuel. Cádiz en el sistema atlántico: la ciudad, sus comerciantes y la actividad. Cádiz: Sílex, 2005. 
Castelo Álvarez, Bernardo. "Rodolfo Ucha Piñeiro." En Arquitectura modernista, ecléctica e rexionalista, editado por Antón Pulido Novoa, 95-149. Vigo: Nova Galicia Ed., 2002.

Castro García, Óscar. "Arquitectura doméstica indiana en Galicia. Los autores de los proyectos arquitectónicos." En Galicia-Cuba: Un patrimonio cultural de referencias y confluencias, editado por Concepción Fontenla San Juan y Manuel Silve, 63-69. Sada: Ed. do Castro, 2000.

---. "Arquitectura doméstica indiana en Galicia." En Indianos. Arquitectura da emigración na península de Bezoucos: Ares, Cabanas, Fene e Mugardos, editado por Bernardo Anatol Seoane y Carlos Ardá Suárez, 14. Ferrol: COAG, 2000.

Charles de Aviler, Augustin. Cours d'architecture qui comprend les ordres de Vignole, avec des commentaires, les figures \& les descriptions de ses plus beaux bâtimens, \& de ceux de Michel-Ange: plusierus nouveaux desseins \& tout ce qui regarde l'art de bâtir: avec une ample explication par ordre alphabetique de tous les termes; premier partie. París: Nicolas Langlois, 1691.

Cortés López, Miriam Elena. "Escalera en la arquitectura indiana gallega. Pervivencia y tradición en las obras de los hermanos García Naveira." Norba. Revista de Arte, no. 31 (2018): 9-29.

Daly, Cesare. Revue Generale de L'Architecture et des Travaux Publics, no. 16 (1858).

---. Revue Generale de L'Architecture et des Travaux Publics, no. 20 (1862).

---. L'Architecture Privée. Nouvelles Maisons de Paris et des Environs. 2 vols. París: Ducheur et Cie, 1872.

Dartein, Fernand de. Étude sur l'architecture lombarde et sur les origines de l'architecture romano-byzantine. París: Dunod, 1865.

---. Architecture lombarde par F. de Dartein. París: Dujardin et Cie, 1892.

François Blondel, Jacques. Architecture Françoise ou Recueil des plans, elevations, coupes et profils des Eglises, Maisons Royales, Palais, Hôtels \& Edifices les plus considérables de Paris, ainsi que des Châteaux \& Maisons de plaisance situés aux environs decette Ville, ou en d'autres endroits de la France, bâtis par les plus célébres Architectes, \& mesurés exactement sur les lieux...Avec la desciption de ces Edifices, \& des Dissertations utiles \& intéressantes sur chaque espèce de Bâtiment. 4 vols. París: Charles-Antoine Jombert, 1752-1754.

Garrido Moreno, Antonio. “La Galería gallega: una tipología tradicional en permanente evolución.” Anuario Brigantino, no. 21 (1998): 379-404.

---. “A imaxe arquitectónica dos indianos galegos.” Estudios Migratorios, no. 11-12 (2001): 319-35.

Garrido Rodríguez, Jaime. Jenaro de la Fuente Dominguez: el gran artifice del ensanche vigués y su abundante obra arquitectónica. Vigo: Instituto de Estudios Vigueses, 2016.

González Lopo, Domingo. "Los Frutos de la emigración, las fundaciones filantrópicas de los indianos gallegos." En Galicia e América: cinco siglos de historia, 213-16. Santiago de Compostela: Consellería de Relacións Institucionais e Portavoz do Goberno, Consello da Cultura Galega, 1992.

Gutiérrez, Ramón, José Ramón Alonso Pereira, y Fernando Álvarez, coords. Julián García Núñez: Caminos de ida y vuelta. Buenos Aires: Cedodal, 2005.

Iglesias Veiga, Xosé Ramón. Arquitectura e indianos na cidade de Vigo e Bisbarra. Vigo: Instituto de Estudios Vigueses, 2013.

Jackson Downing, Andrew. A Treatise on the theory and practise of landscape gardening adapted to North America; with the improvement of country residences. New York \&London: Wiley and Putnam, 1844.

---. The Architecture of Country Houses, including designs for cottages, farm-houses, and villas. New York: D. Appleton \& Co., 1851.

Lizancos Mora, Plácido. "A aventura americana na conformación da vivenda e outras arquitecturas de Gali- 
cia. Percorrido histórico." En Galicia-Cuba: Un patrimonio cultural de referencias y confluencias, editado por Concepción Fontenla San Juan y Manuel Silve, 37-46. Sada: Ed. do Castro, 2000.

---. "Influencia das migracións na vivenda galega contemporánea." En Identidades Multiculturais, editado por Ana Bringas López y Belén Martín Lucas, 233-40. Vigo: Servicio de Publicacións Universidade de Vigo, 2000.

López Vázquez, José Manuel. "Juan de Ciórraga y Fernández de la Bastida.” En Galicia. Arte. T. 15, editado por Francisco Rodríguez Iglesias, 143-44. A Coruńa: Hércules, 1993.

Martínez Plasencia, Mercedes, y Teresa Sánchez Cora. Ponte Caldelas. Memoria escrita dun pobo (15001936). Vol. 4. Ponte Caldelas: Deputación de Pontevedra, 2004.

Mella, Edoardo A. Elementi di architettura lombarda redatti da Edoardo Mella. Torino, Fratelli Bocca, 1885.

Morales Saro, María Cruz. Arte, cultura y sociedad en la emigración española a América. Oviedo: Servicio de Publicaciones de la Universidad de Oviedo, 1992.

Moure Pazos, Iván. "Las villas de Luigi Manini en Sintra (1890-1912).” Ángulo Recto: Revista de estudios sobre la ciudad como espacio plural 6, no. 2, (2014): 103-6.

---. "Un trozo de Italia en el corazón de Sintra: la obra de Luigi Manini para Victor Carlos Sassetti en el Monte da Lua." Laboratorio de Arte: Revista del Departamento de Historia del Arte, no. 29 (2017): 636-52.

Peña Saavedra, Vicente. "Das fundacións docentes dos indianos ás escolas de americanos, catro séculos de intervención escolar dos emigrantes galegos." En I Encontros Galicia-América, editado por Roberto IrimiaVázquez y Juan Francisco Froján Fontán, 53-79. Santiago de Compostela: CIHUGA, 1992.

---. "Educar: el compromiso de la añoranza fecunda: entre la filantropía docente de los "indianos" y la obra escolarizadora de las Sociedades de Instrucción (SS. XVI-XXI).” En Ciudadanos españoles en el mundo: situación actual y recorrido histórico, 55-102. Vigo: Grupo España Exterior, 2008.

Rocamonde, Teresa. "Os irmáns García Naveira, empresarios na Arxentina e filántropos en Betanzos." Eco: revista do Eixo Atlántico, no. 327 (2018): 44-49.

Rodríguez Dacal, Carlos. “O mundo verde de Villa Honorata, casa indiana modélica lamesa.” A Pedreira: revista cultural e turística do Concello da Lama, no. 10 (2012): 13-33.

Rodríguez Paz, Diego. "La Torre de los Moreno en Ribadeo: un ejemplo singular de la arquitectura indiana en Galicia.” Anuario Brigantino, no. 33 (2010): 337-92.

Ruiz de Lacanal Ruiz-Mateos, María Dolores. El patrimonio natural y cultural de Rota (Cádiz) y su conservación. Cádiz: Universidad de Cádiz, 2007.

Salgado, Fernando. "Los hermanos García Naveira." En Historias de Galicia. T. 3. La riqueza que emergió del mar, 265-70. A Coruña: La Voz de Galicia, 2017.

Sánchez García, Jesús Ángel. "Entre la persistencia de lo autóctono y la seducción por lo foráneo. Espacios residenciales en Galicia en los siglos XIX y XX (pazos, quintas, villas y chalets).” En Espais Interiors. Casa i Art des del segle XVIII al XXI, editado por Rosa Creixell, Terese M. Sala, y Esteve Castañer, 233-44. Barcelona: Publicacions i Edicions, Universitat de Barcelona, 2007.

Segarra Prado, José. "A propósito de "Villa Pilar" una aproximación al "cotage" suizo." El Museo de Pontevedra, no. 41 (1987): 309-53.

Sixirei Paredes, Carlos. "Habaneros." En Casas de Indianos, editado por Fernando Bores Gamundi, 13-33. Santiago de Compostela: Xunta de Galicia, 2000.

Soraluce Blond, José Ramón. "La arquitectura ecléctica en Galicia." Abrente, no. 35-37, (2005): 183-226. Táboas, Teresa. Emigración e Arquitectura “Os Brasileiros”. Pontevedra: Deputación de Pontevedra, 1998. Viollet-le-Duc, Eugene. Habitations Modernes. París: A. Morel et Cie., 1877. 


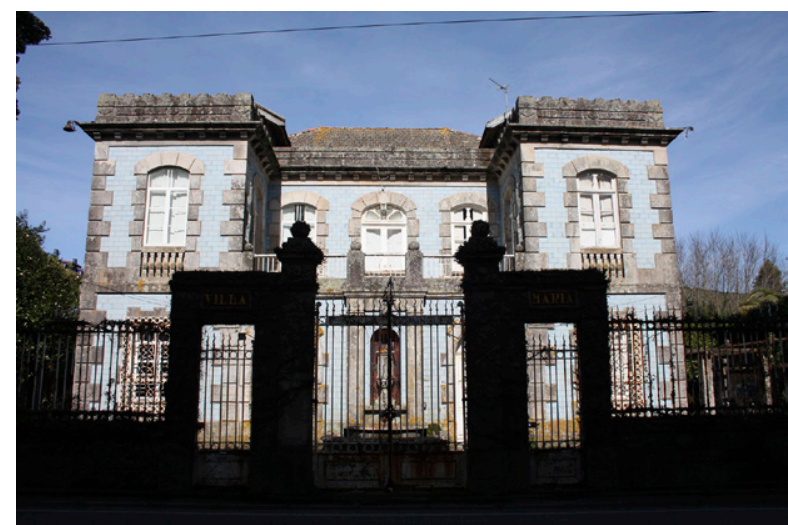

Villa Domínguez (Villa María), ¿1890? A Guarda, Pontevedra.

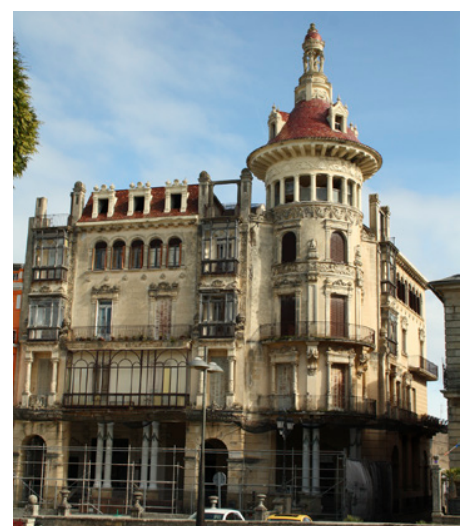

Torre de los Moreno, 1912. Ribadeo, Lugo.

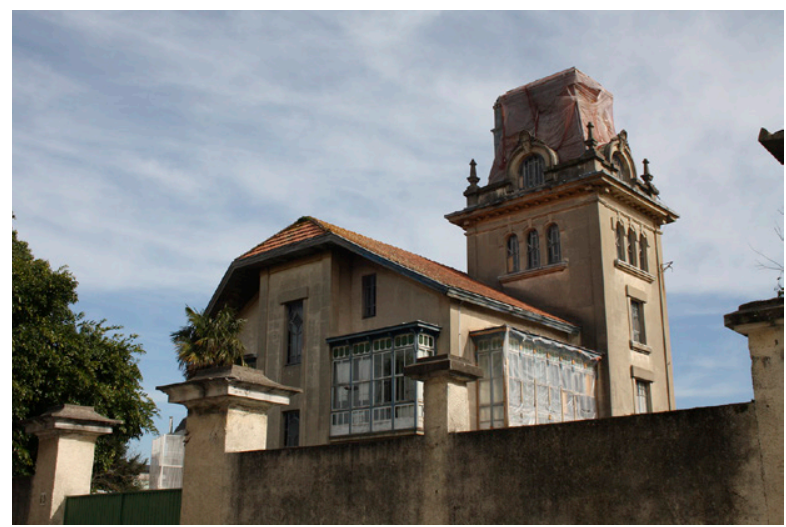

Casa Canido, 1923-25. Ferrol, A Coruña.

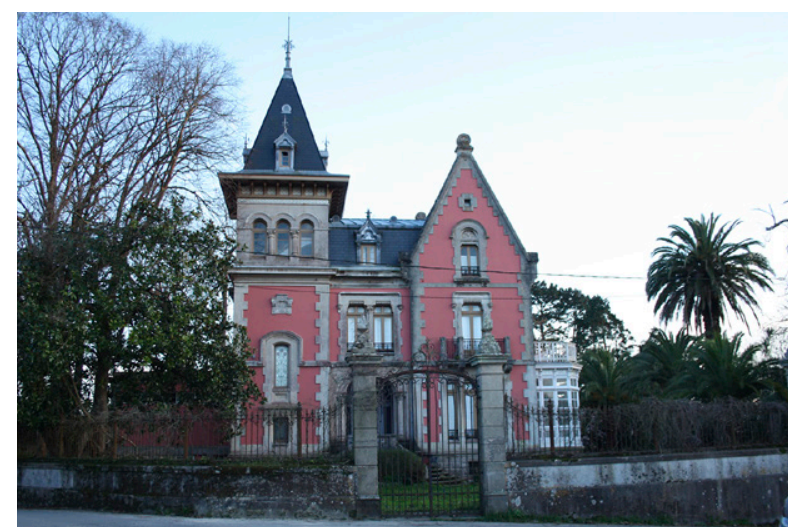

Villa Isabel, 1899. San Pedro de Nos. O Vilar, A Coruña.

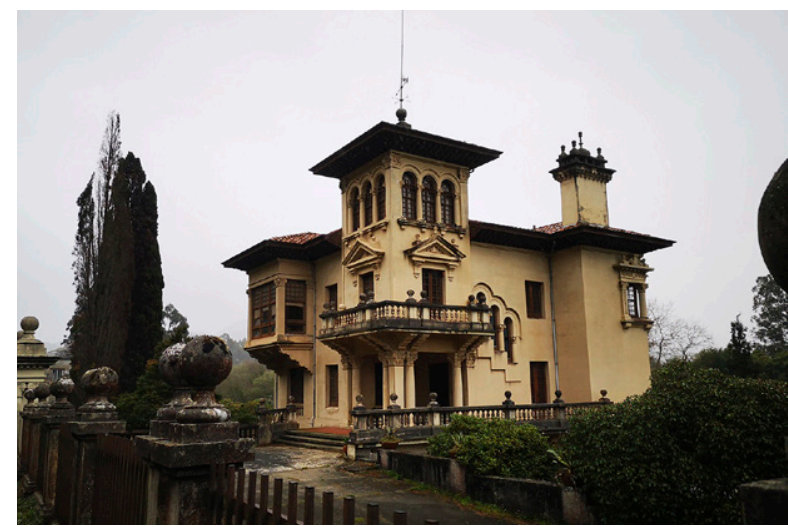

Casa del Fondón, 1927. Magazos. Viveiro, Lugo.

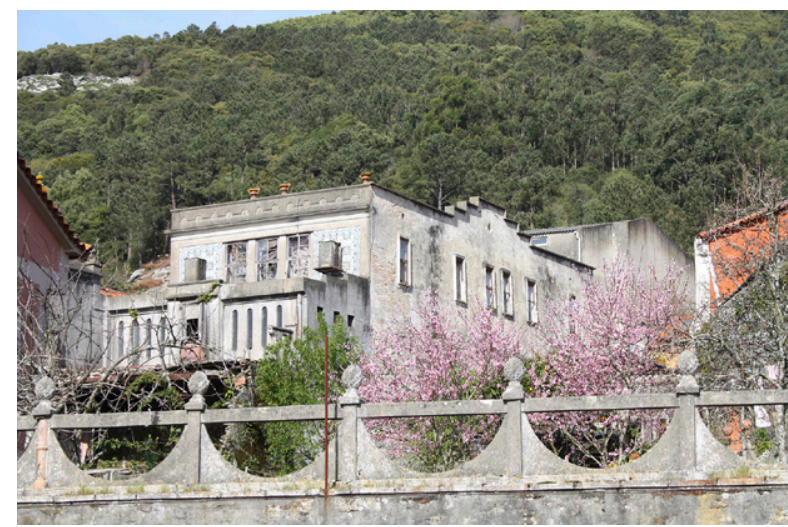

Casa de Valeriano Portela, 1894. Camposancos. A Guarda, Pontevedra. 


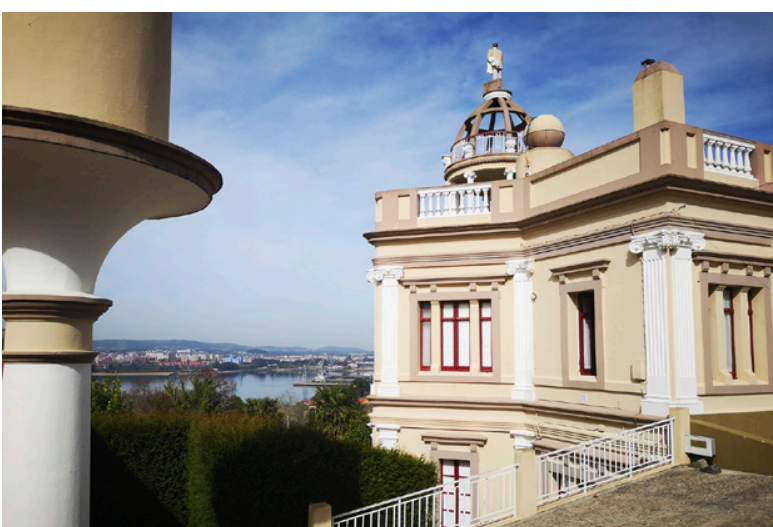

Villa El Adriano, 1921. Barallobre. Fene, A Coruña.

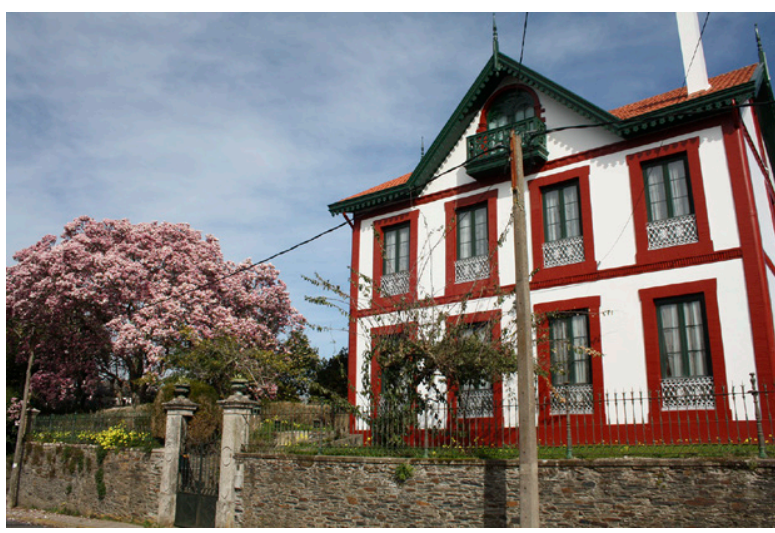

El Chalet, 1860. O Seixo. Mugardos, A Coruña.

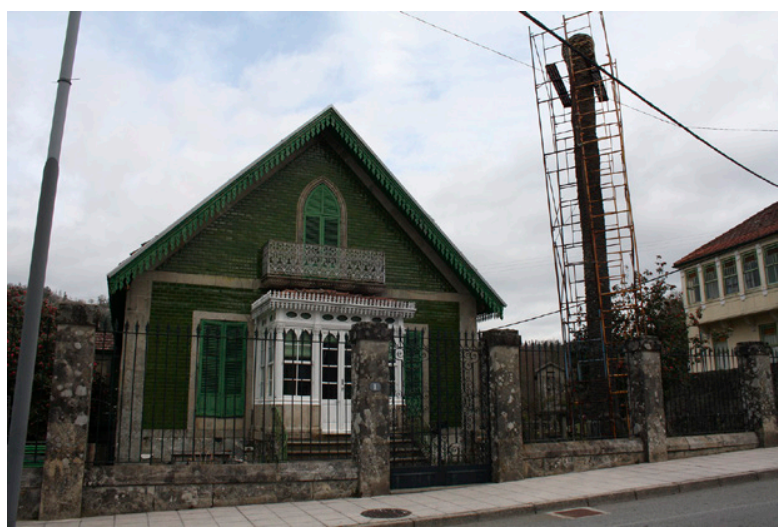

La Casa de José Estévez Fernández ("Casa Verde"), ca. 1895. Ponte Caldelas, Pontevedra.

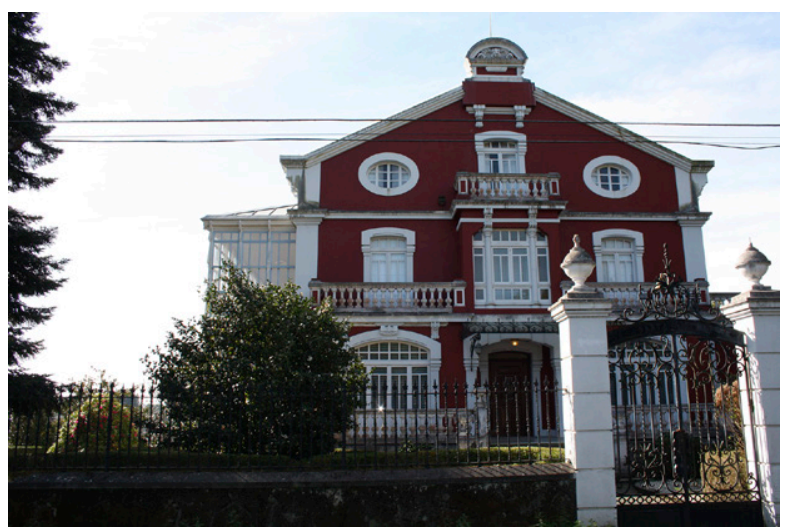

Villa Amalia, 1919. Camouco. Ares, A Coruña.

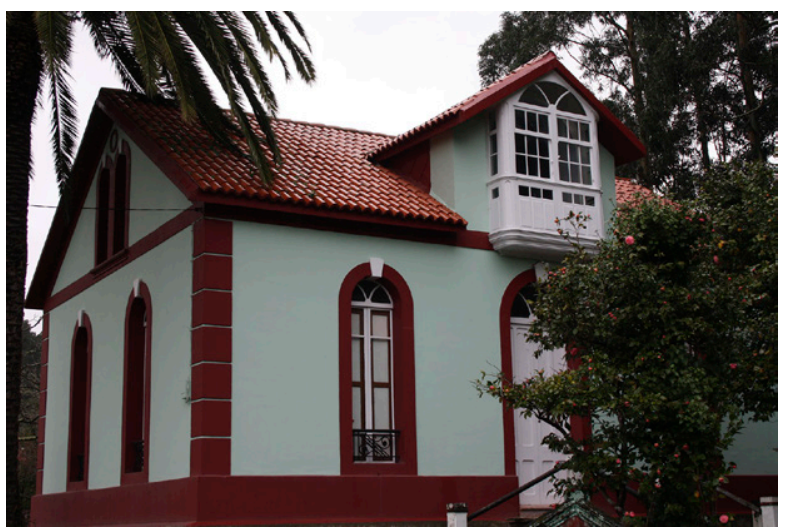

Villa Enedina, ca. 1900. A Lamestra. Cariño, A Coruña.

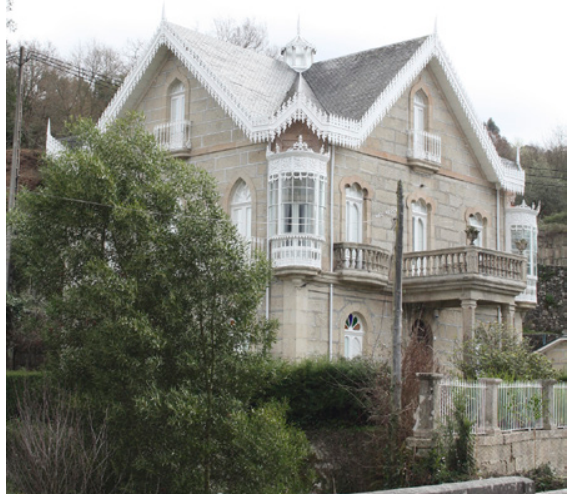

Casa del Sr. Oubiña ("O Meu Repouso"), 1910-15. Gaxate. A Lama. Pontevedra. 


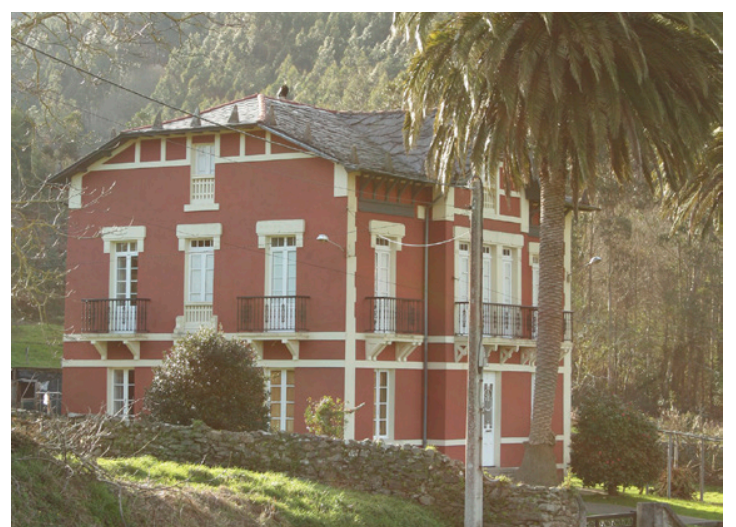

Casa del Señorón, 1926. Chao de Ourol. Ourol, Lugo.

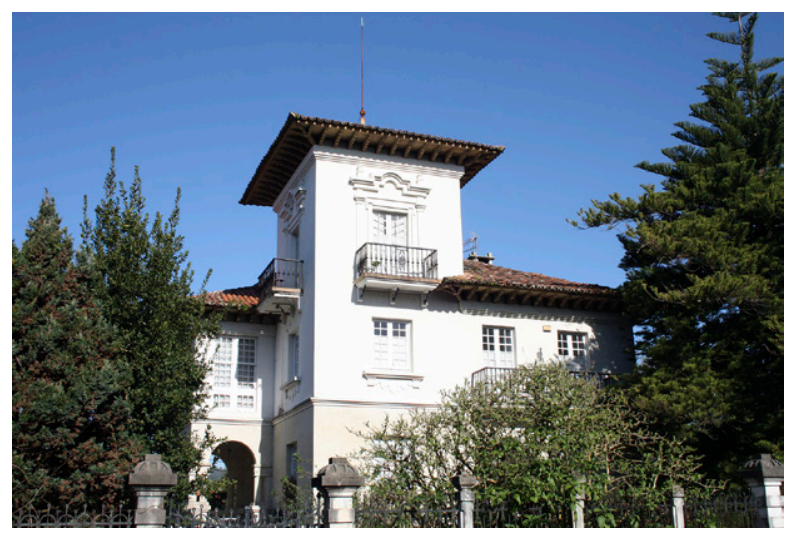

Casa Arenal, 1930-40. Cabanas, A Coruña.

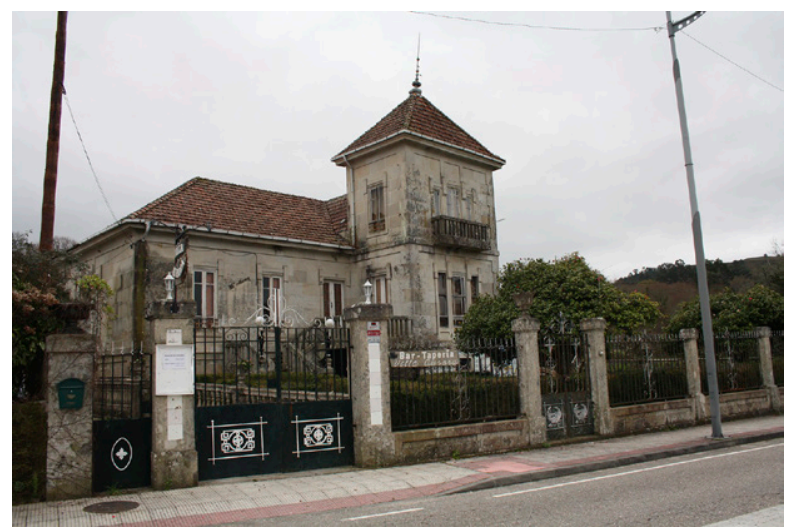

Villa Aurora (Calixto Albán), 1930. Fornelos de Montes, Pontevedra.

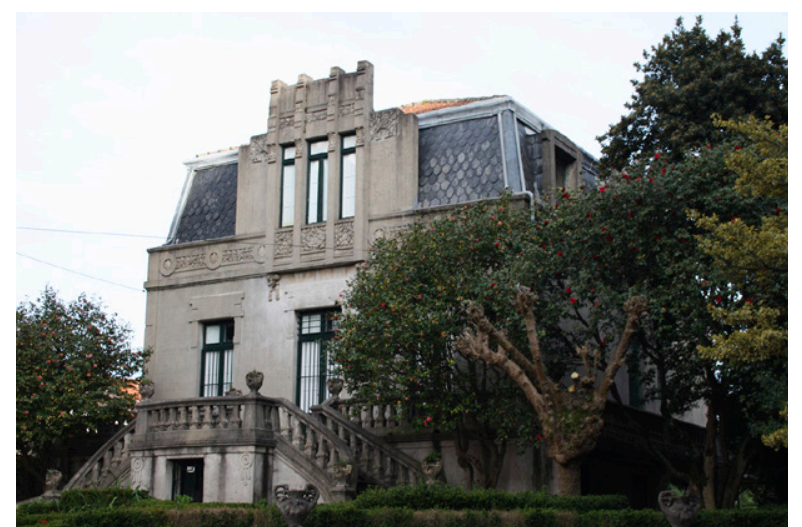

Casa en Vilagarcía, s/d. Vilagarcía de Arousa, Pontevedra.

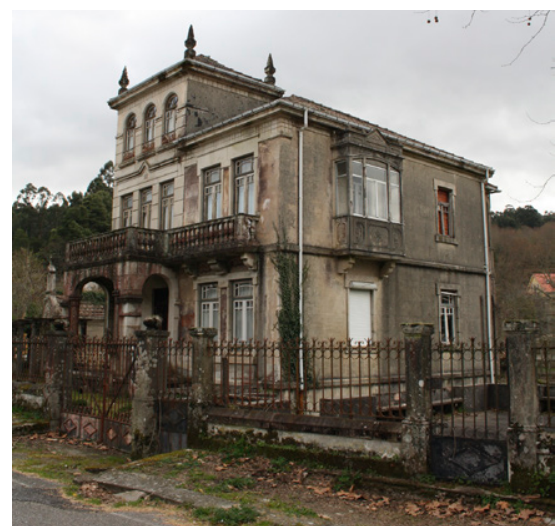

Casa en Gaxate, inicios s. XX. A Lama, Pontevedra.

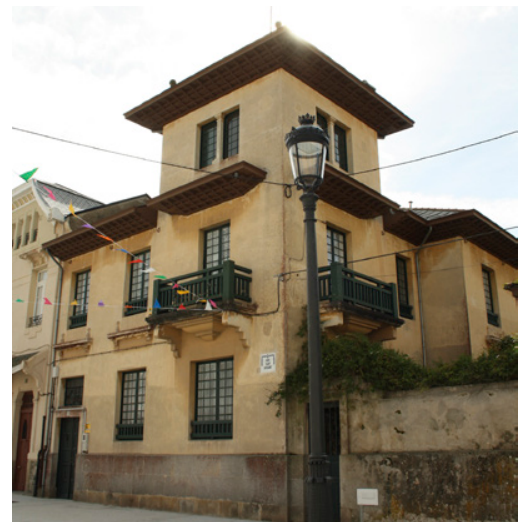

Casa de los Enanos, ¿1927? Ribadeo, Lugo. 


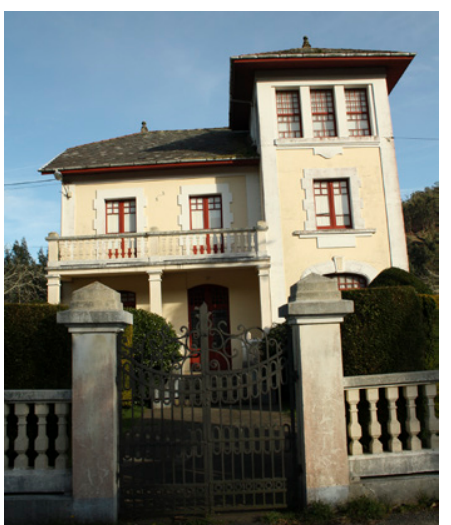

Casa García, 1930. Chao de Ourol. Ourol, Lugo.

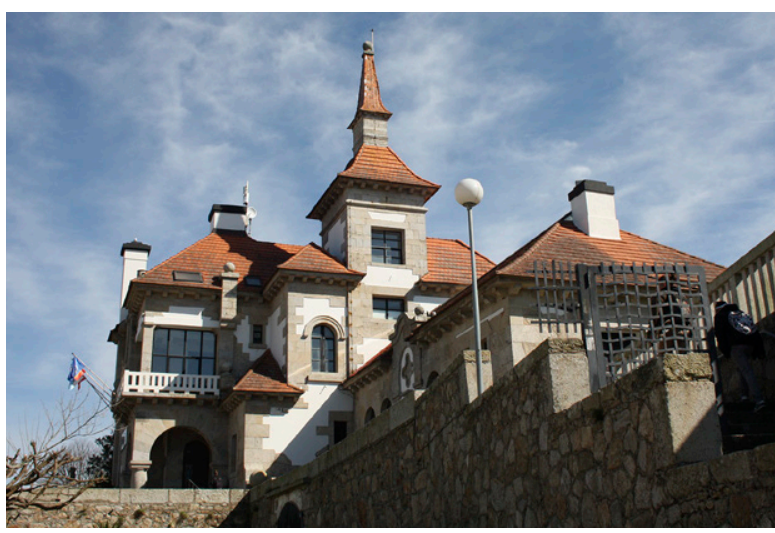

Villa Domínguez (Villa María), ¿1890? A Guarda, Pontevedra.

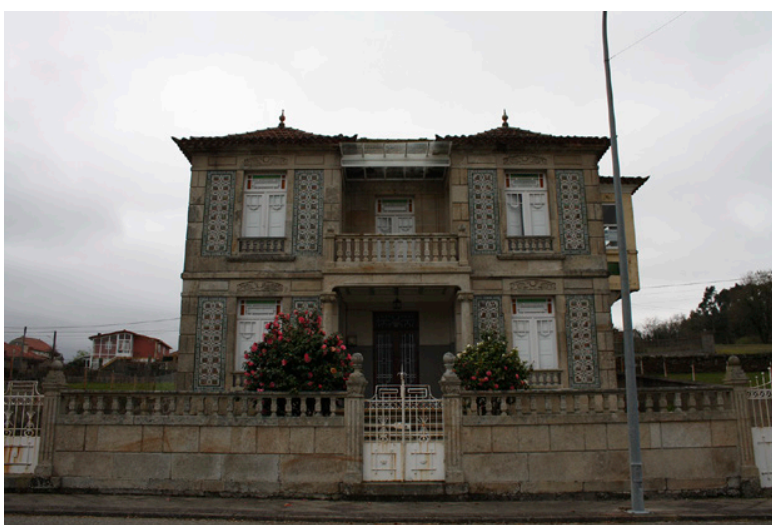

Casa de Laurentino. Moscoso, 1927. Pazos de Borbén, Pontevedra.

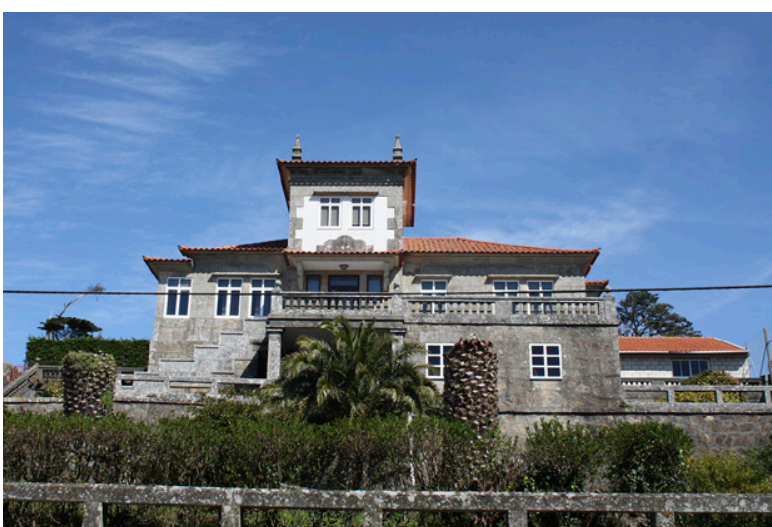

Casa de Serafín Flores Sobrino, 1930. A Guarda, Pontevedra.
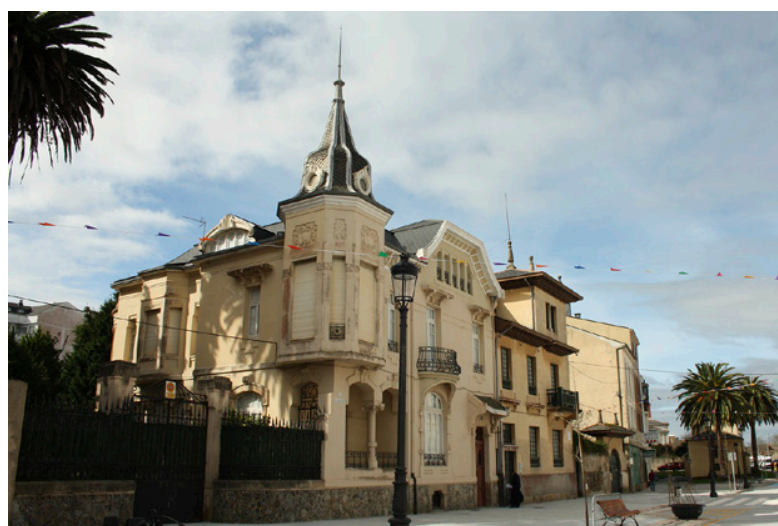

Casa en la Calzada, 1910. Ribadeo, Lugo.

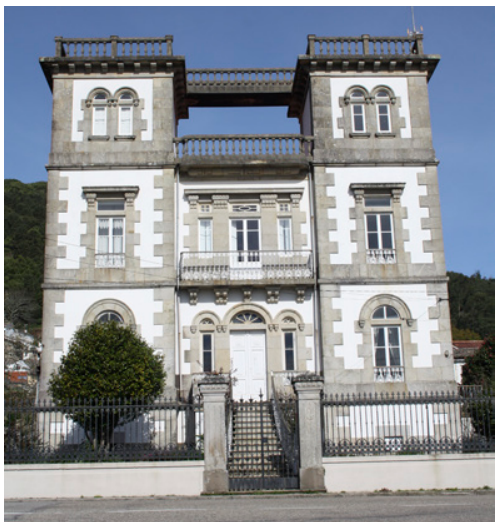

Casa de las Torres, ¿1920? Camposancos. A Guarda, Pontevedra. 


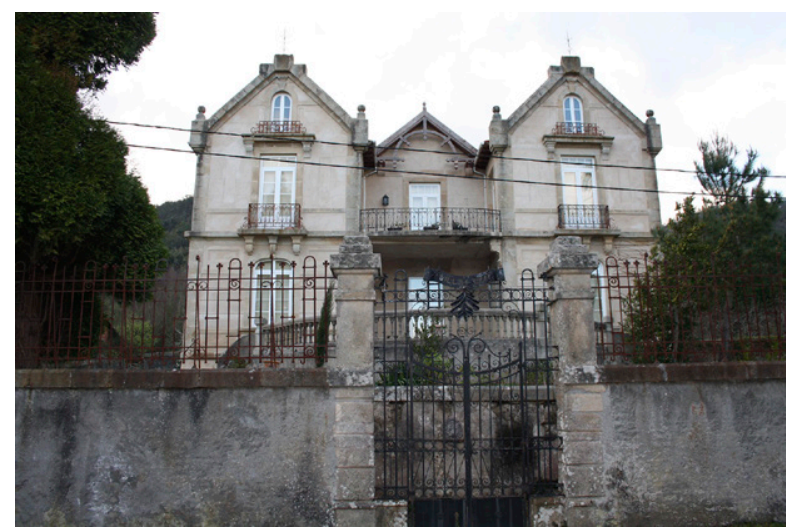

Villa Lola, 1880. Merille. Ourol, Lugo.

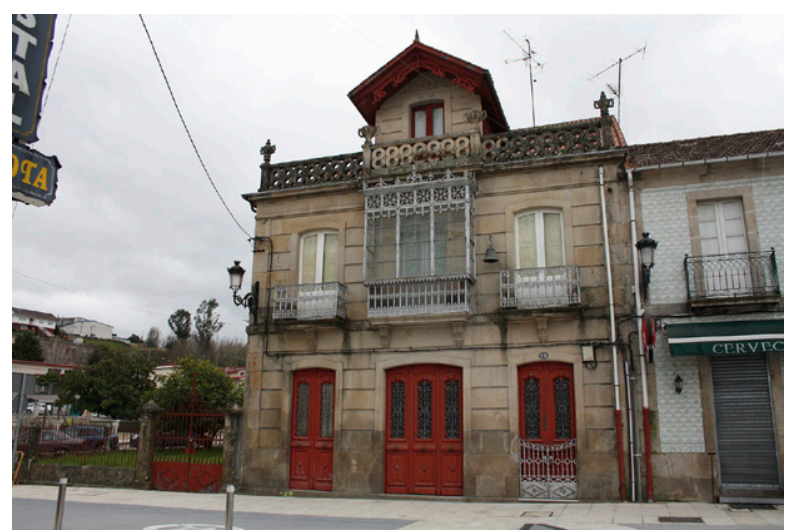

Casa de Ma Dolores Méndez Muíños ("Casa de la Campana"), 1915. Ponte Caldelas, Pontevedra.

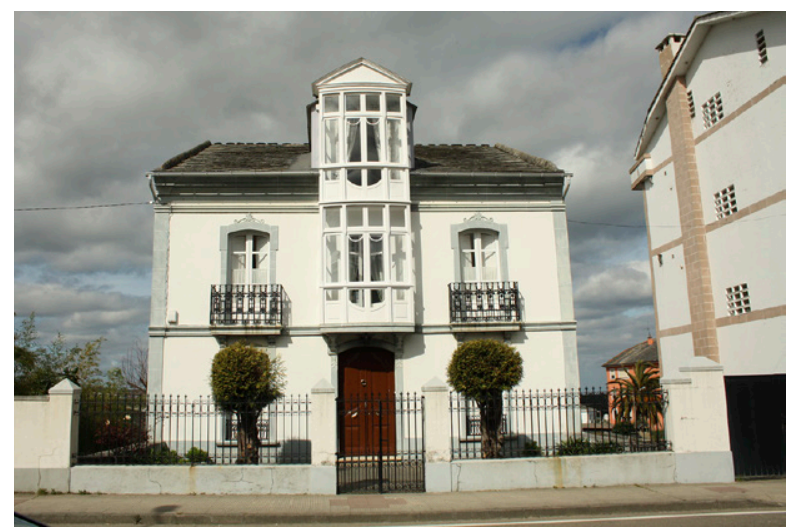

Casa de Neira, 1911. Barreiros, Lugo

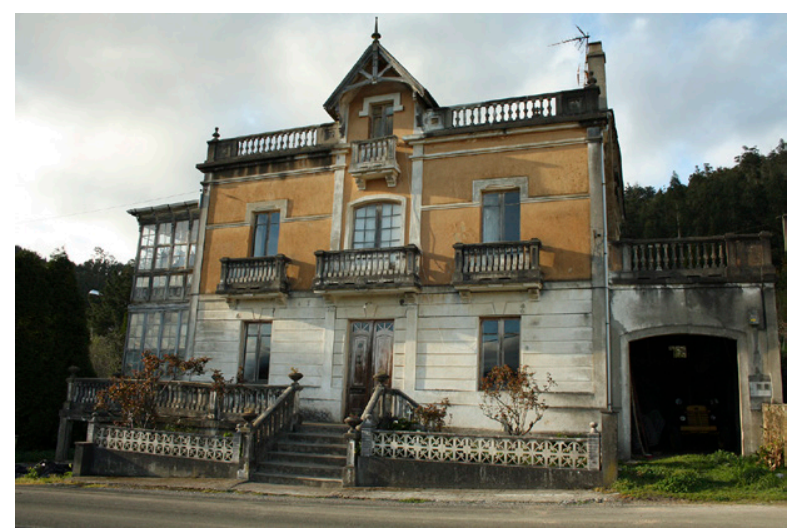

Casa de Pita, 1920. Merille. Ourol, Lugo.

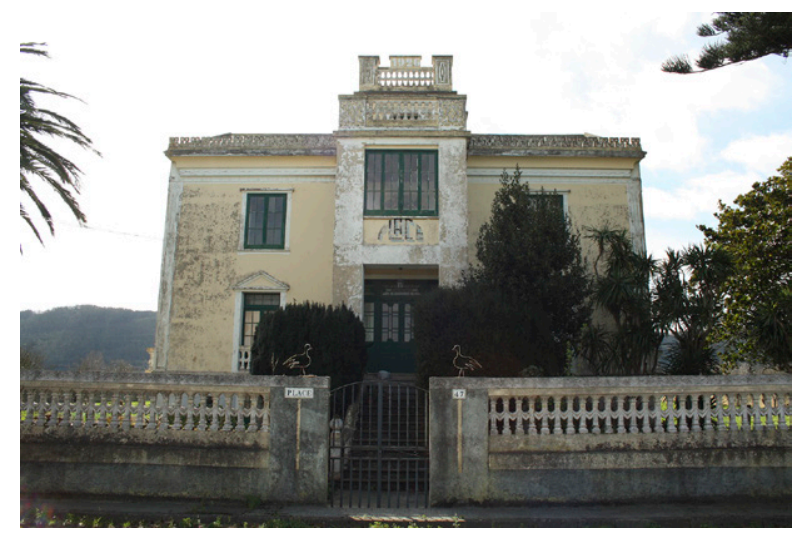

Place Margarita, 1926. A Devesa. Ribadeo, Lugo.

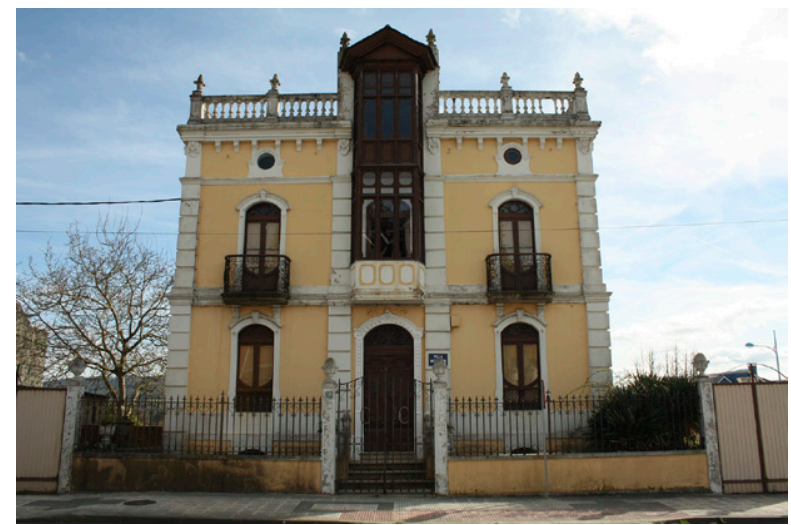

Villa Modesta, 1911. Foz, Lugo. 


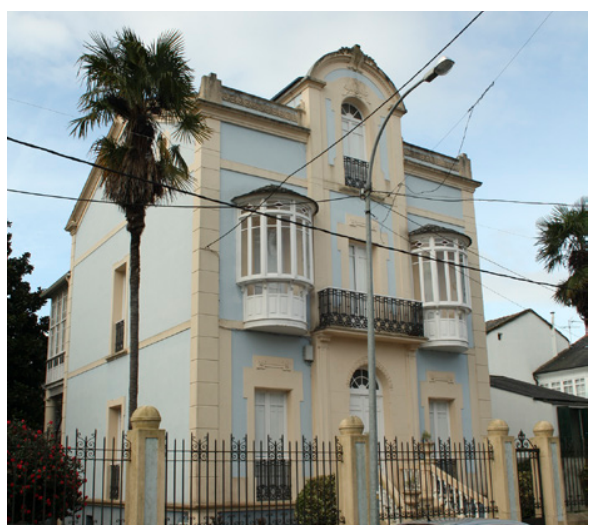

Villa Miguelito, 1925. Vilanova de Lourenzá, Lugo.

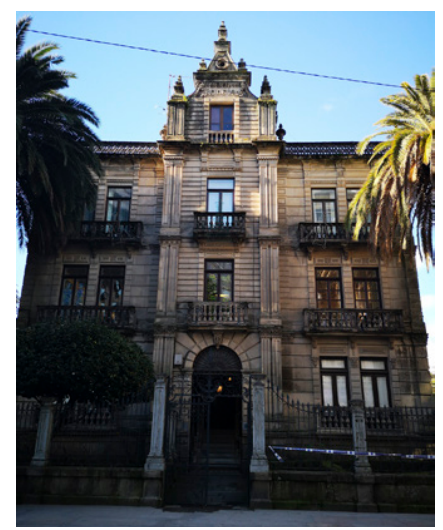

Villa Pilar, 1905. Pontevedra.

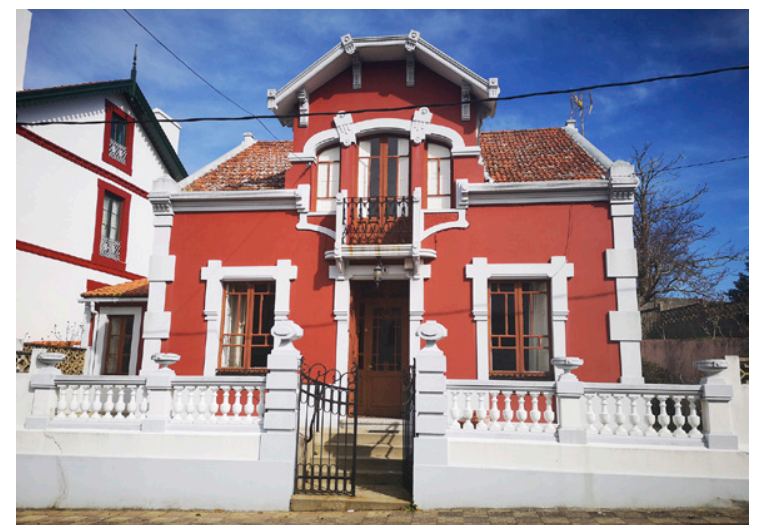

Casa colindante al Chalet de O Seixo, 1924. O Seixo. Mugardos, A Coruña.

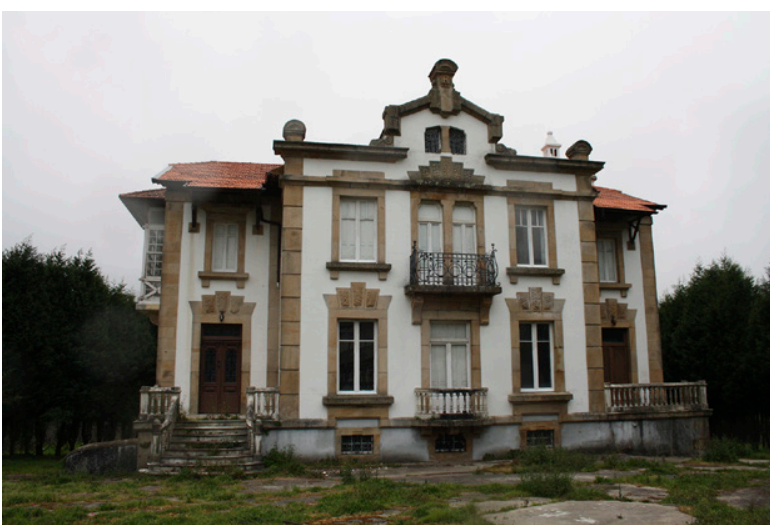

Villa María, 1920. Magazos. Viveiro, Lugo.

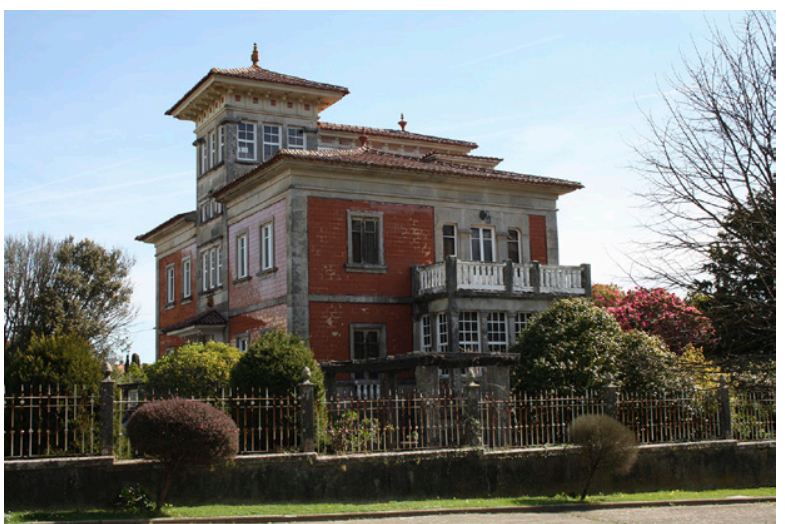

Casa de Manuel Alonso Sobrino, 1928. A Guarda, Pontevedra.

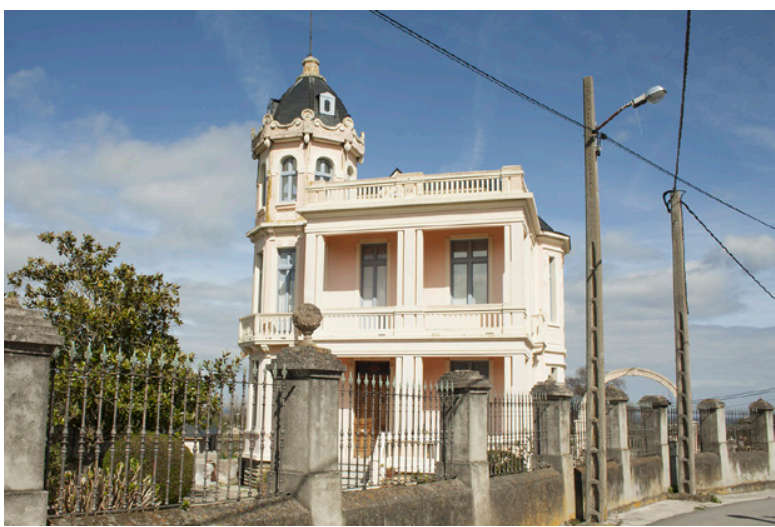

Villa Julia, 1926. San Miguel de Reinante. Barreiros, Lugo. 


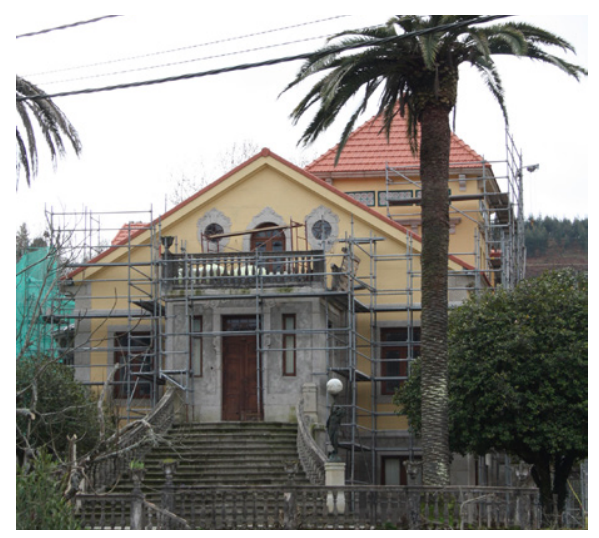

Villa Honorata, 1929. Gaxate. A Lama, Pontevedra.

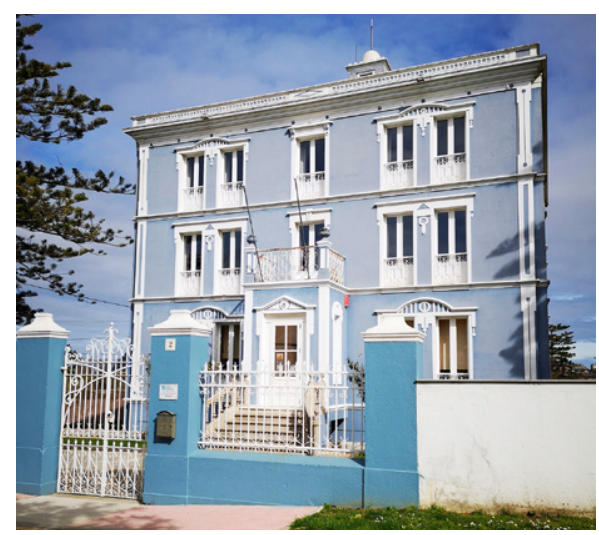

Casa del Óptico, 1900-10. Ribadeo, Lugo.

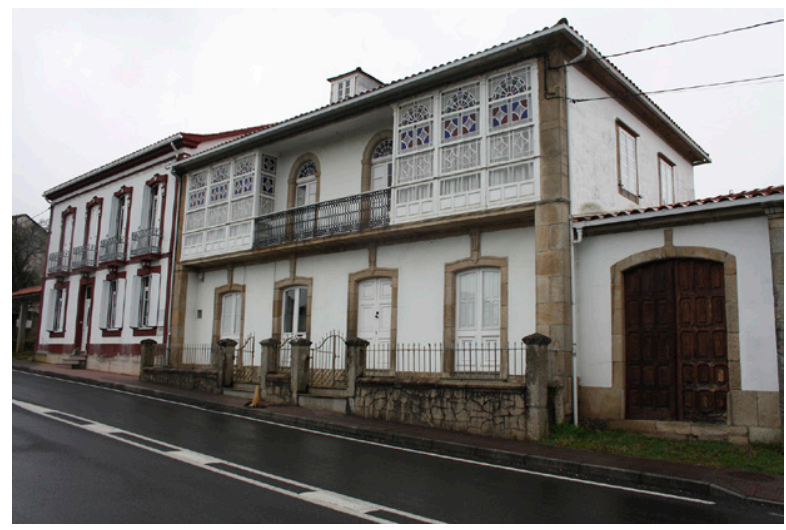

Casa Rico, 1885-88. San Adrián de Veiga. Ortigueira, A Coruña

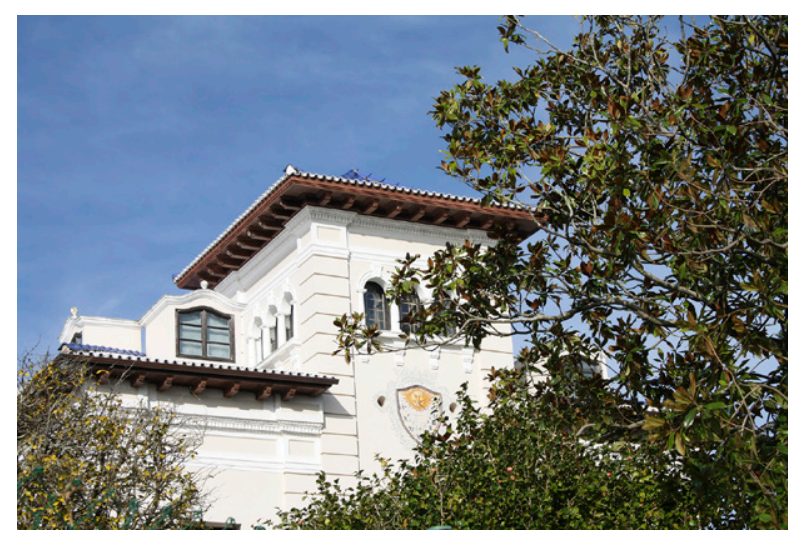

Villa Libunca, 1918. Castro. Narón, A Coruña.

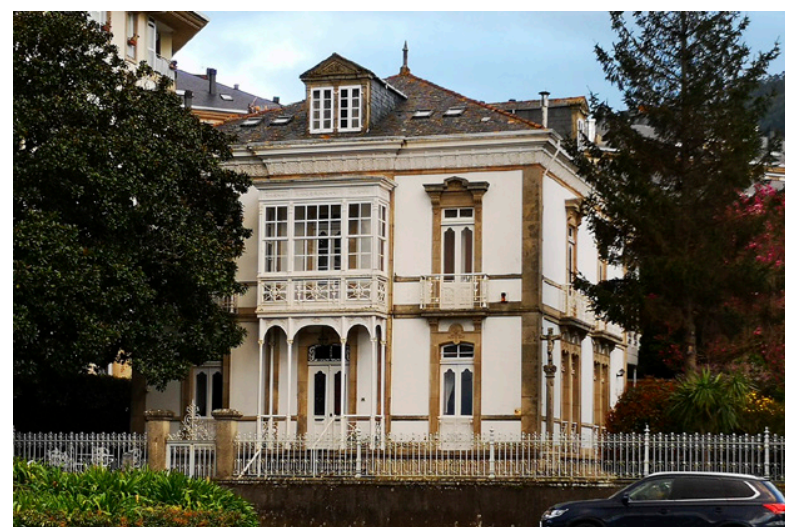

Casa de Benito Galcerán, 1900. Viveiro, Lugo.

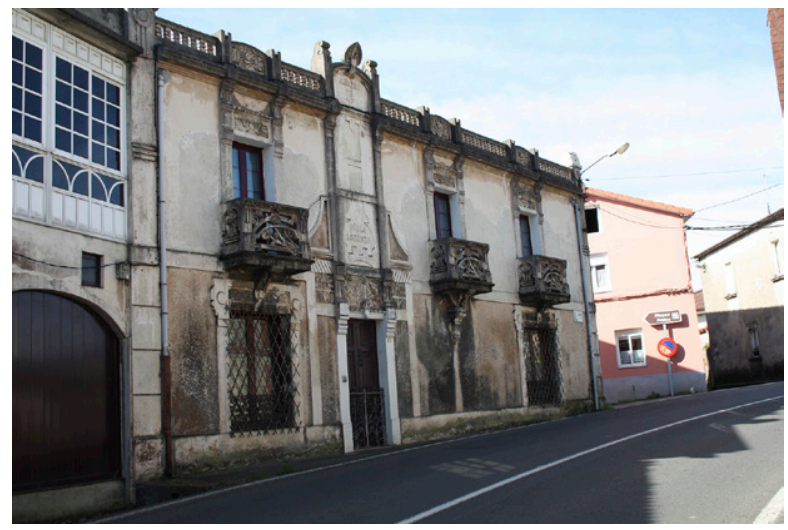

Villa Lorenza, 1911. Limodre. Fene, A Coruña. 


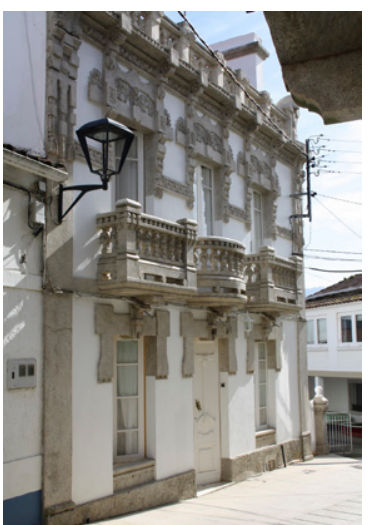

Casa de Paco Bello, 1900-15. Camouco. Ares-A Coruña.

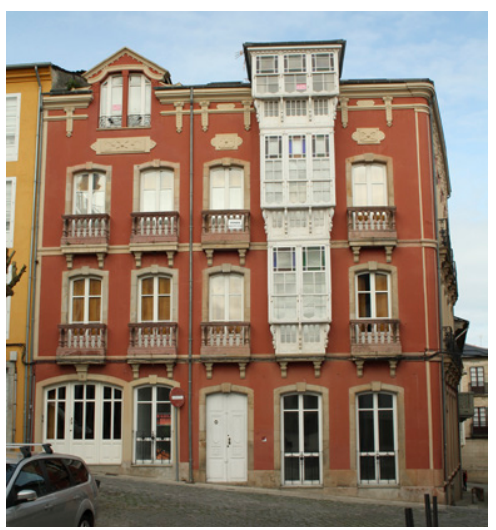

Casa de Don Clemente, 1900-10. Ribadeo, Lugo.

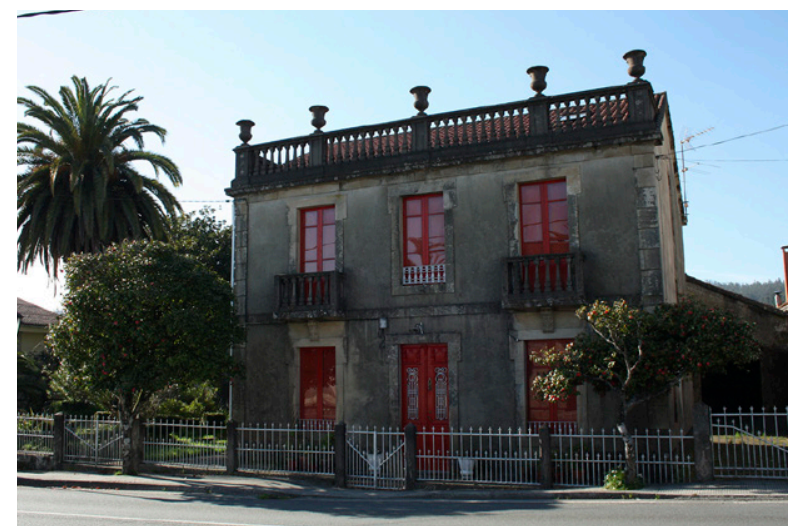

Casa de Jesús Blanco, 1931. Brión, A Coruña.

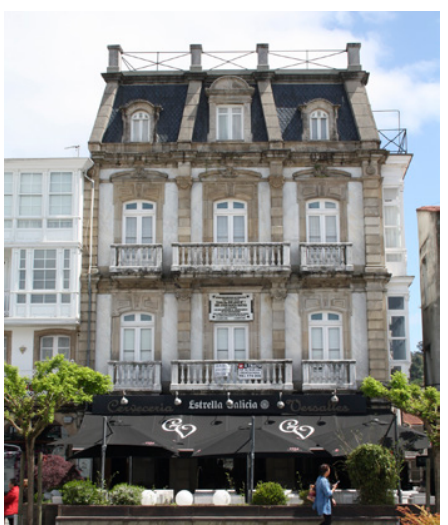

Casa de Juan Naveira, 1900. Betanzos, A Coruña.

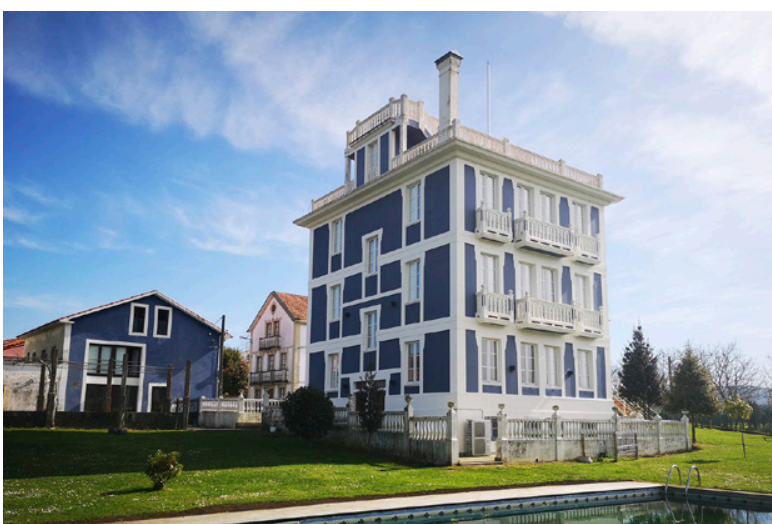

"La Minerva". Casa de Barracido, 1930. Camouco, Ares, A Coruña

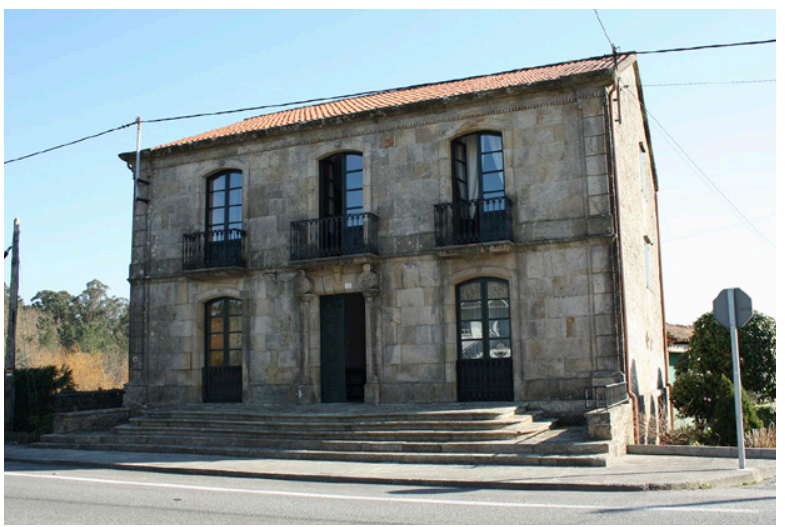

Casa América, 1898. Ángeles. Brión, A Coruña. 


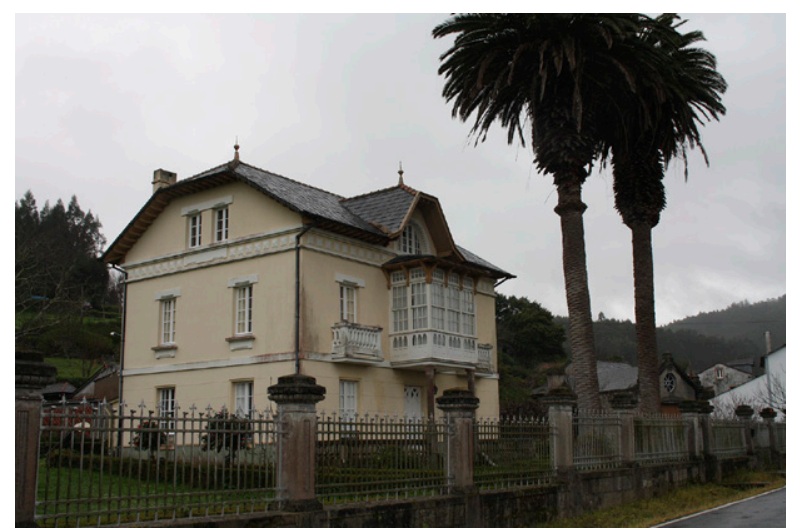

Casa de Carelle, 1910. San Claudio. Ortigueira, A Coruña.

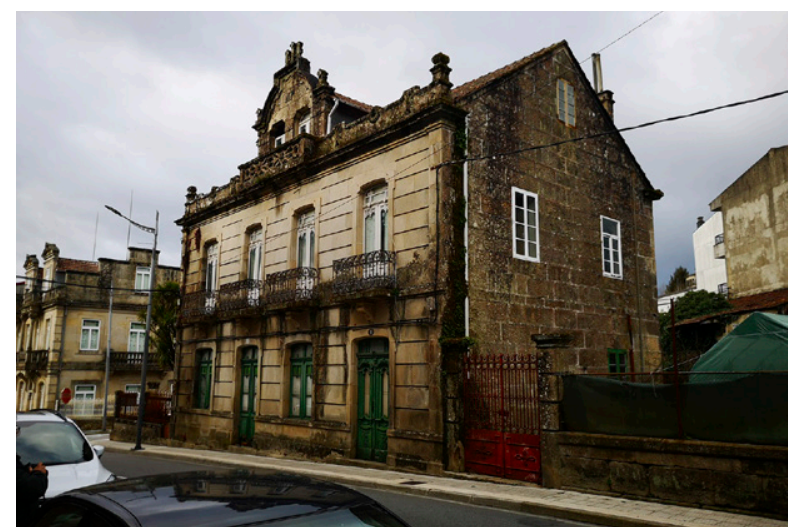

Casa de Manuel Piñeiro Boullosa, 1920. Ponte Caldelas, Pontevedra.

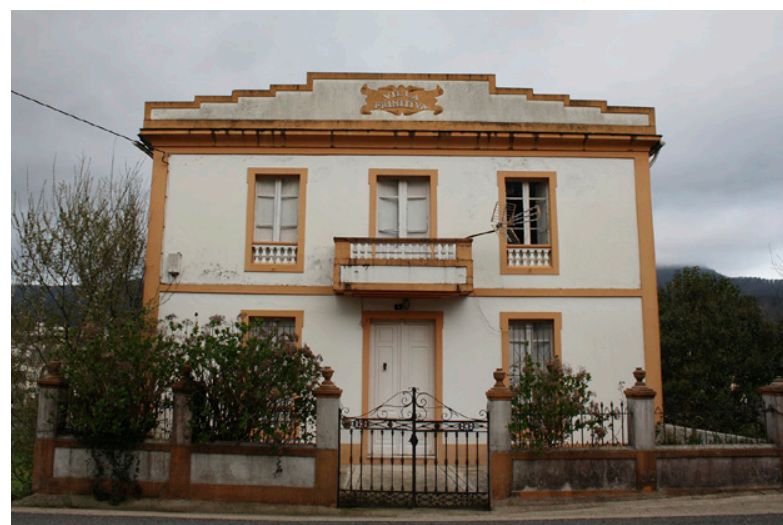

Villa Primitiva, 1953. Mondoñedo, Lugo.

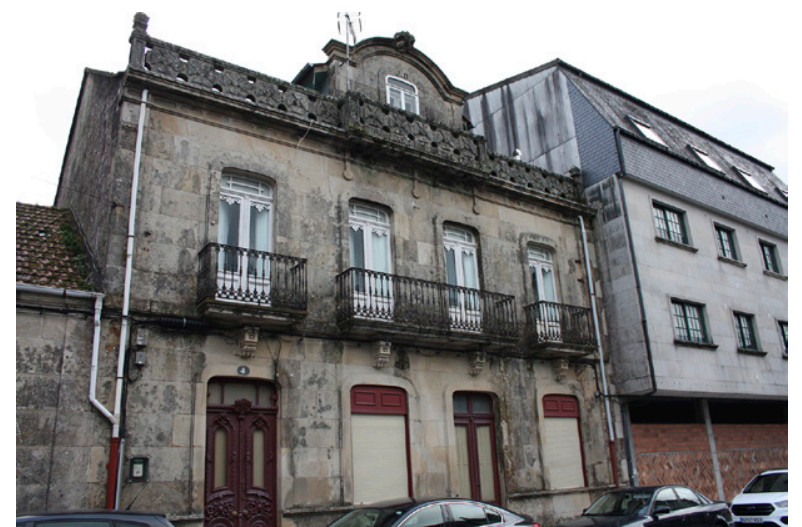

Casa de José Barreiro Barreiro, 1915. Ponte Caldelas, Pontevedra.

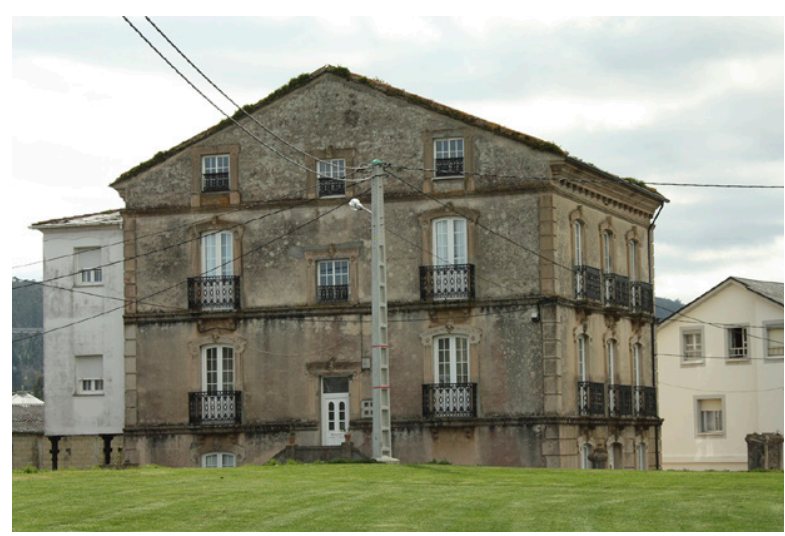

Casa Grande. 1904-07. San Cosme. Barreiros, Lugo.

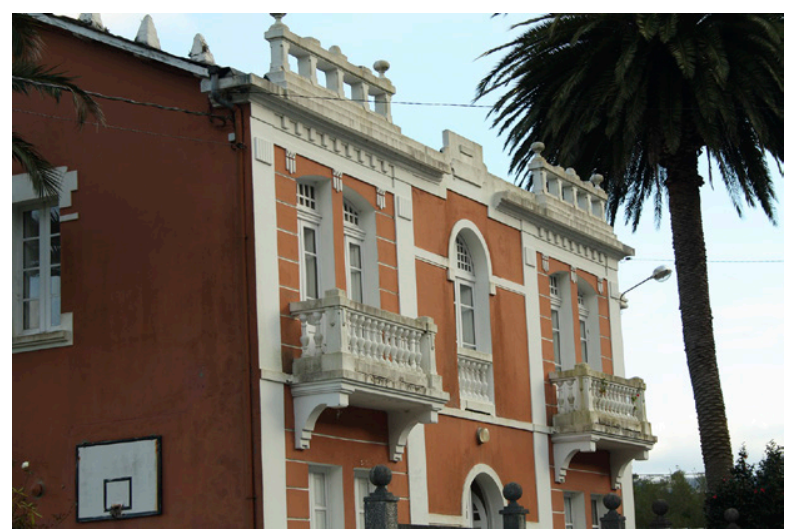

Casa de Carballido, 1920. Merille. Ourol, Lugo. 


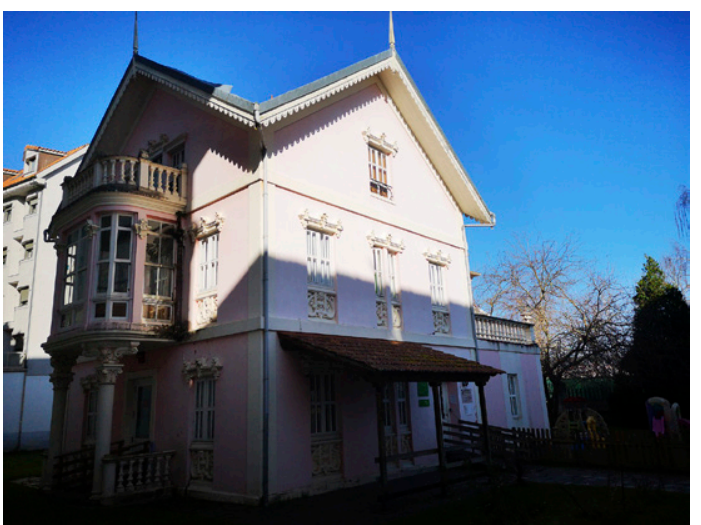

Casa Rosa, 1902. Pontedeume, A Coruña.

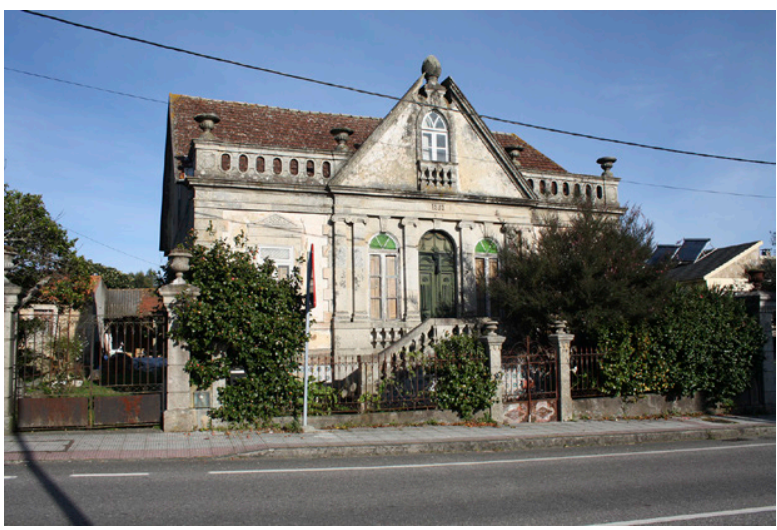

Casa de Gerardo Fernández Troncoso, 1909. Goián. Tomiño, Pontevedra.

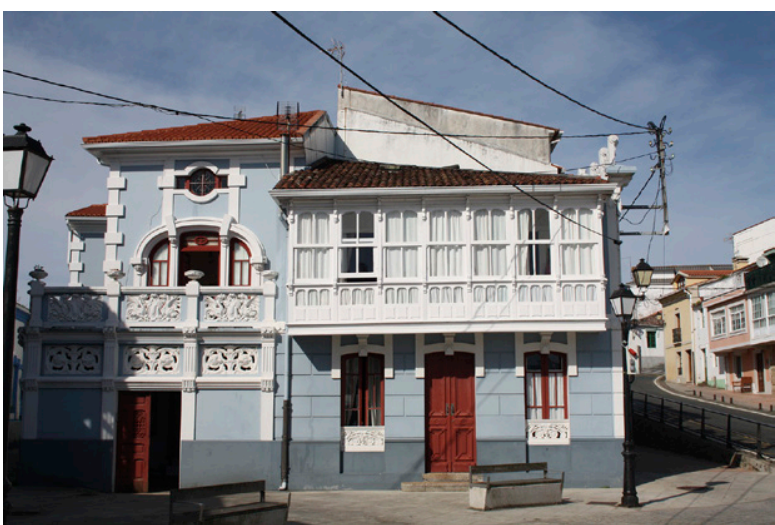

Casa de Concha Amado, 1915. Camouco. Ares, A Coruña

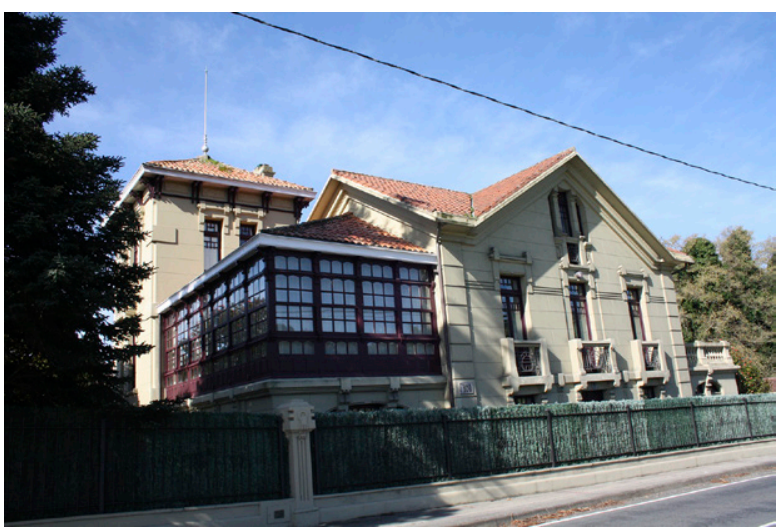

Villa Frayán, 1920. San Martín de Porto. Cabanas, A Coruña.

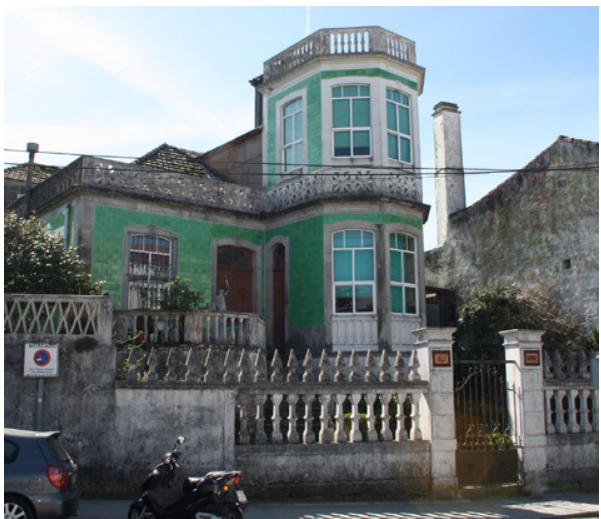

Villa Borinquen, 1910. A Guarda, Pontevedra.

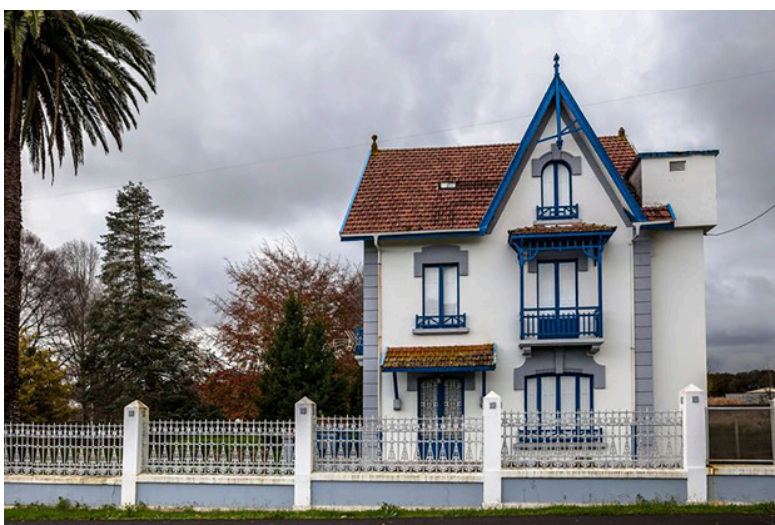

Casa de Nelle, s/d. Castro. Narón, A Coruña. 


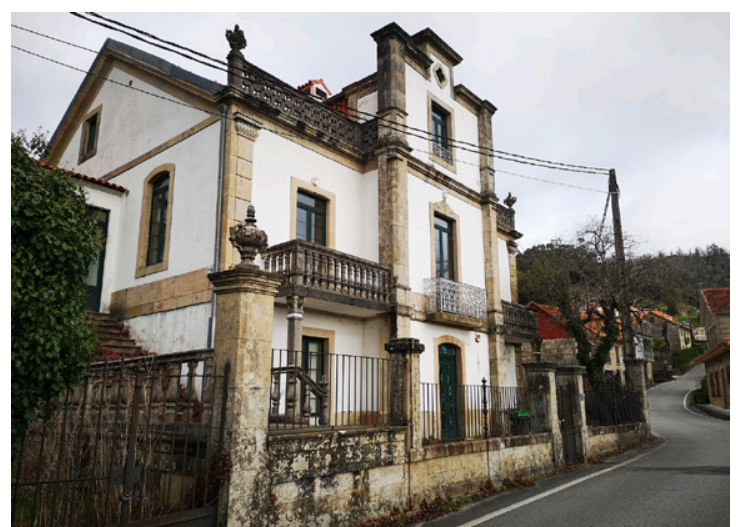

Casa de Raquel Moreira Marín, 1920. Ponte Caldelas, Pontevedra.

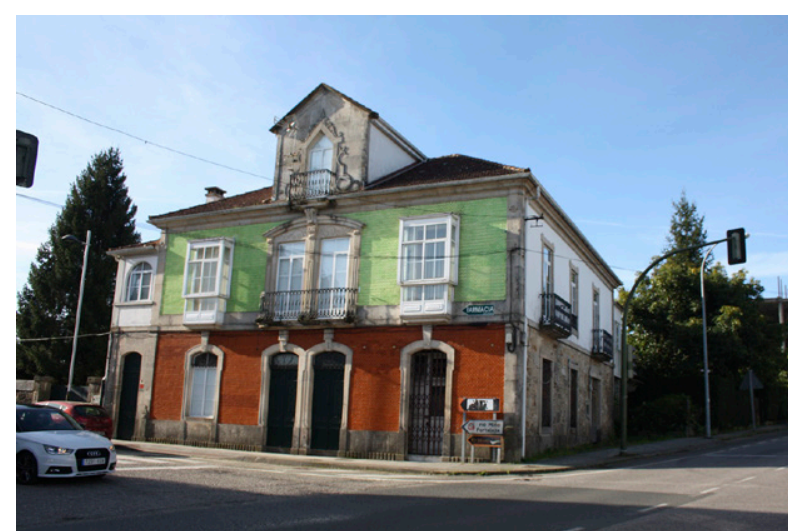

Casa de Juan Troncoso, 1907. Goián. Tomiño-Pontevedra.

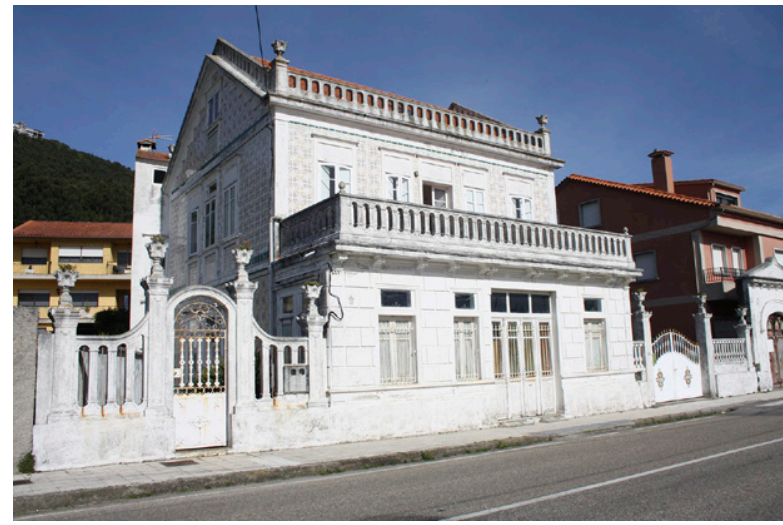

Villa Estrella, ¿1900? Camposancos. A Guarda, Pontevedra.

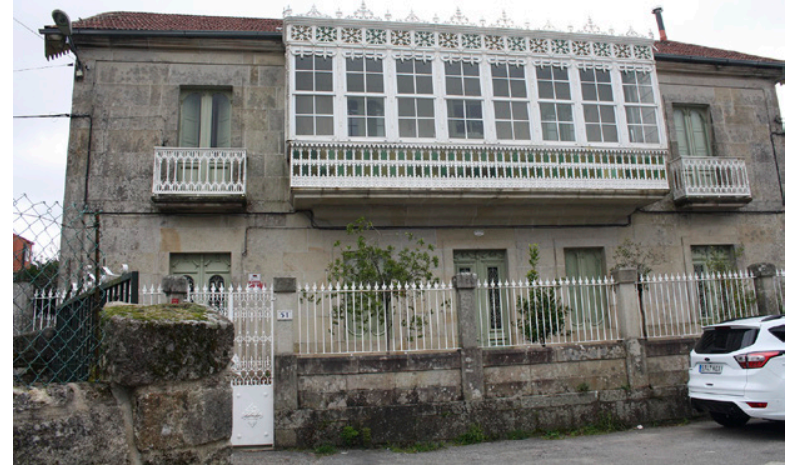

Casa de Lino Bouzas Bouzas, 1915. Anceu. Ponte Caldelas, Pontevedra.

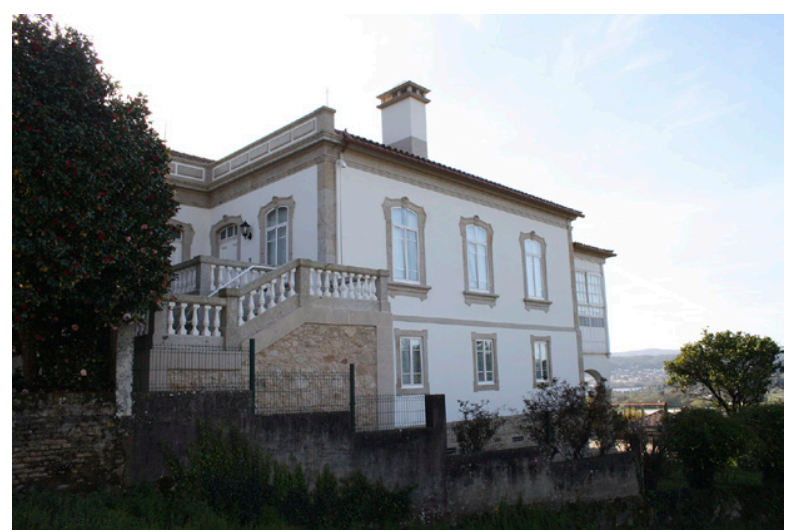

Casa de los Baquero, 1920. San Miguel de Tabagón. O Rosal, Pontevedra.

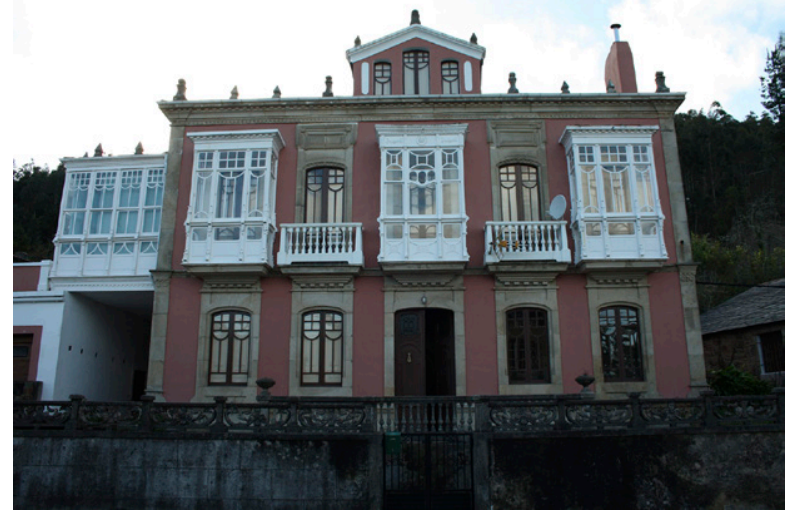

Casa del Mesón, 1930. Ourol, Lugo. 


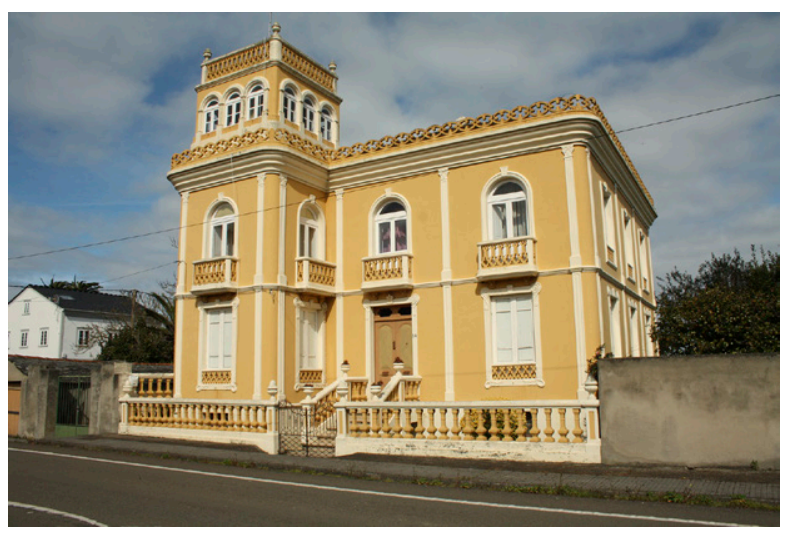

Casa Torre Maseda, 1924. A Devesa. Ribadeo, Lugo.

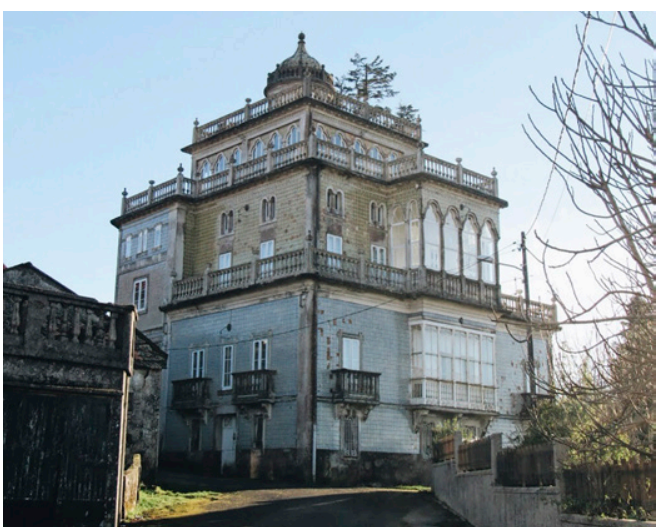

Casona de Soutelo, 1931. Forcarei, Pontevedra.

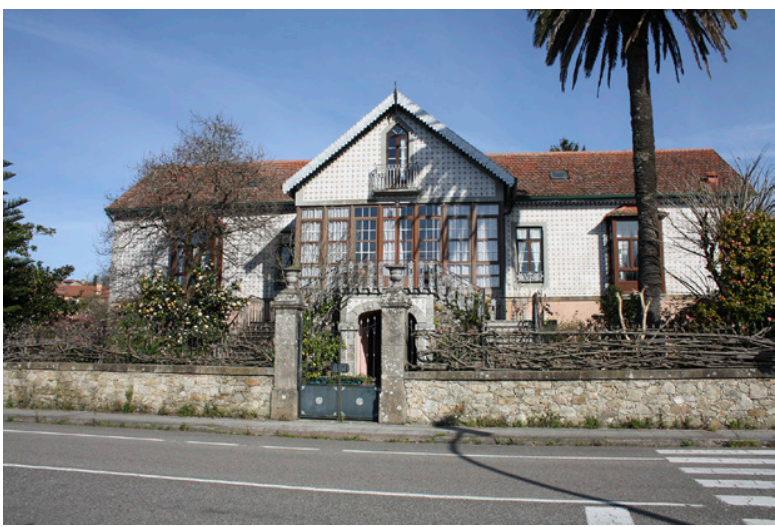

Casa del Almacén, 1905-12. San Miguel de Tabagón. O Rosal, Pontevedra.

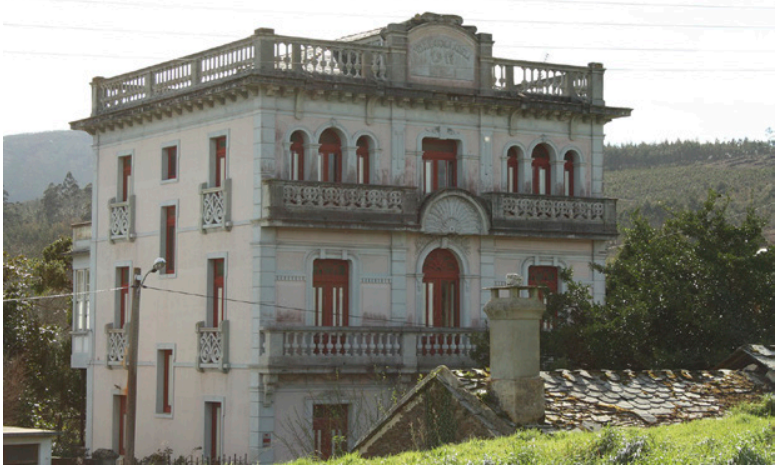

Villa Adela, 1917. Vilaronte. Foz, Lugo.

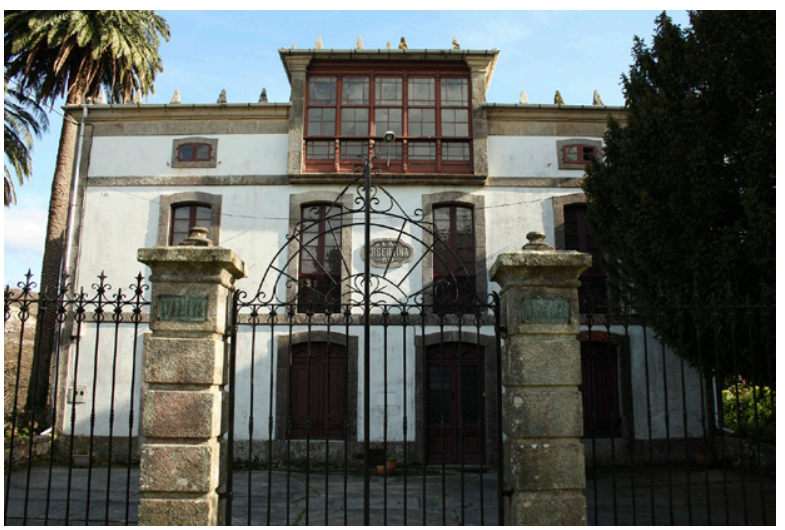

Villa Argentina, 1910. San Román de Villaestrofe. Cervo, Lugo.

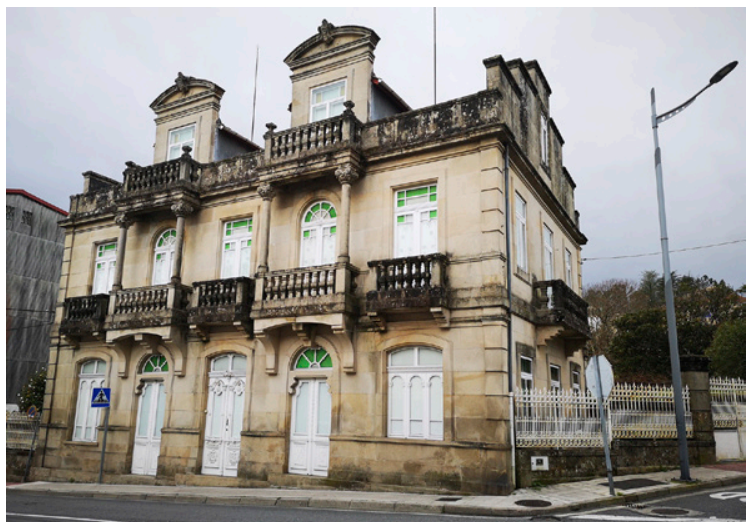

Casa de Rodríguez, 1914. Ponte Caldelas, Pontevedra. 


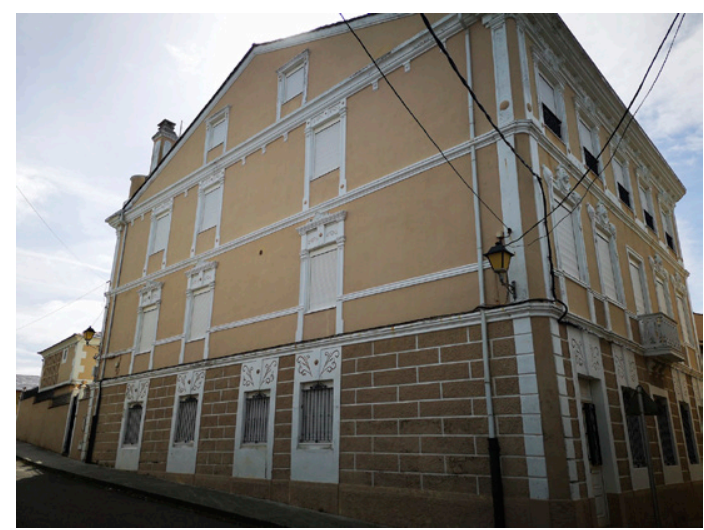

Casa de Don Inocencio, 1912. Rinlo. Ribadeo, Lugo.

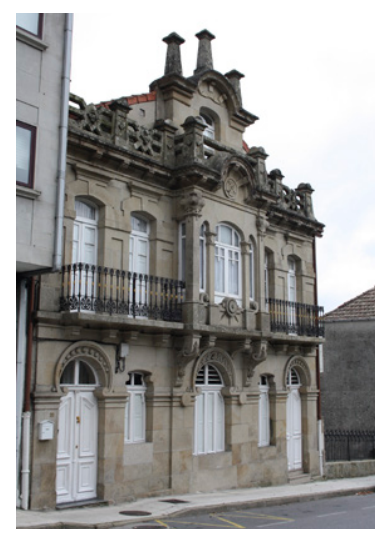

Casa de Manuel Martínez, 1916. Ponte Caldelas, Pontevedra.

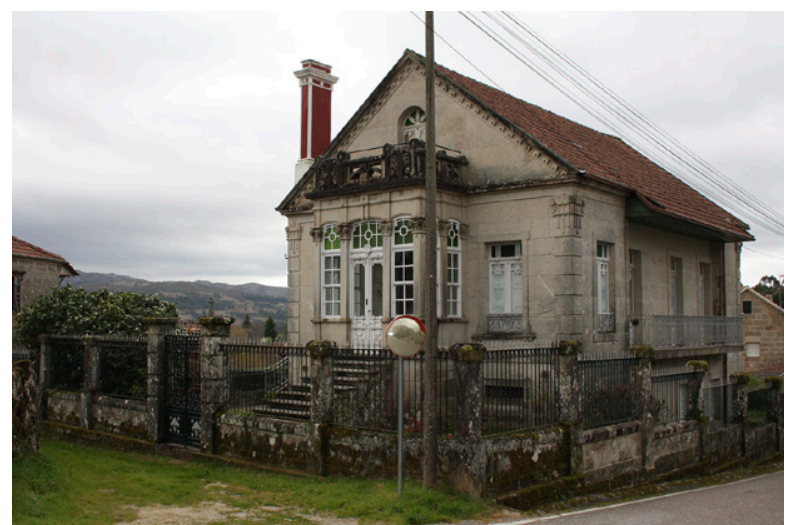

Casa de Casiano Pérez Lorenzo ("La Cendona"). 1920. Anceu. Ponte Caldelas, Pontevedra.

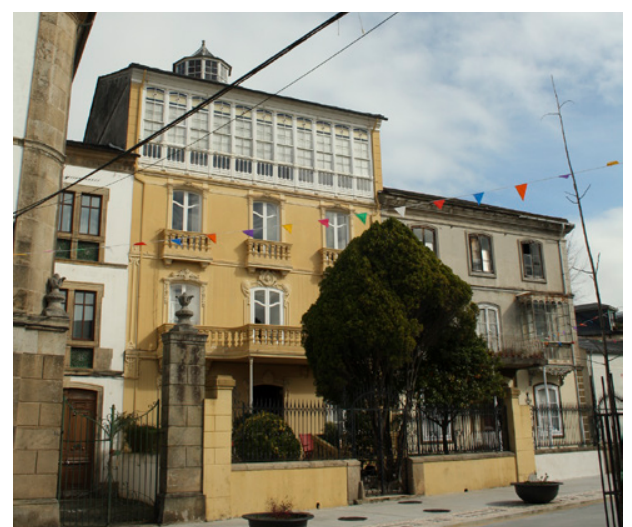

Casa en Rúa San Roque 16, 1886. Ribadeo, Lugo.

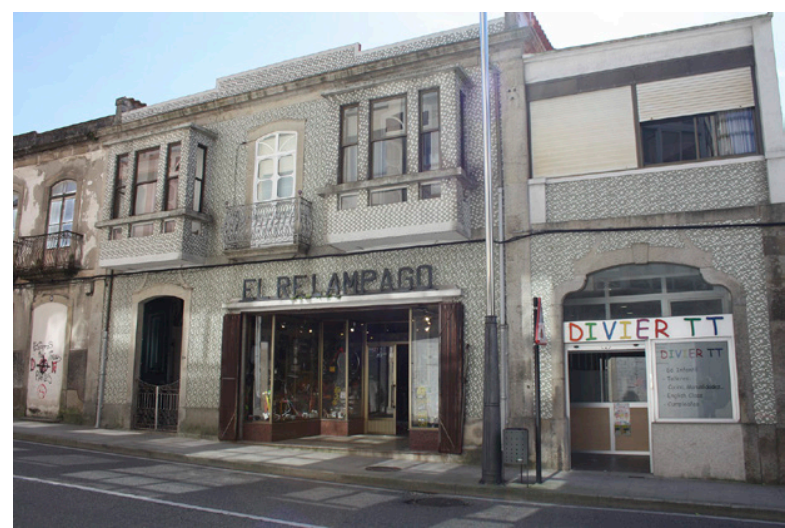

Casa El Relámpago, ¿1890? A Guarda, Pontevedra.

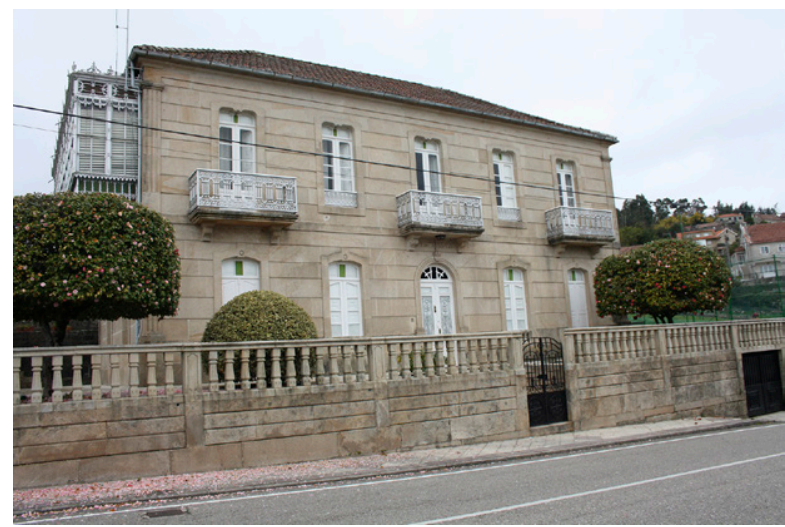

Casa de Daniel Moscoso. 1944. Pazos de Borbén, Pontevedra. 


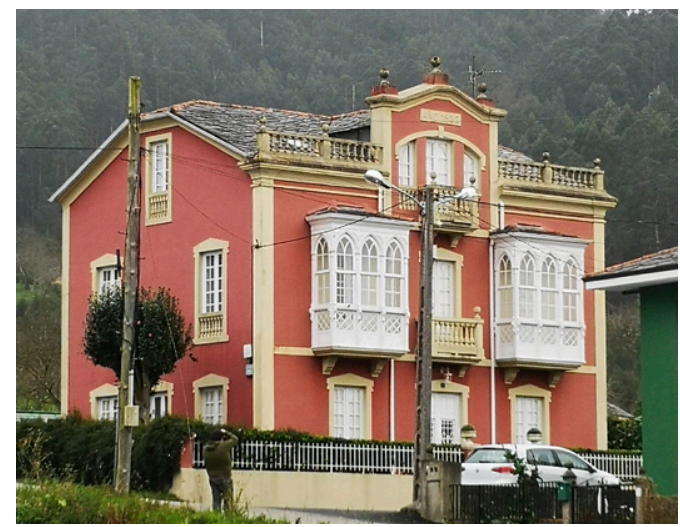

Casa del Atallo, 1932. Magazos. Viveiro, Lugo.

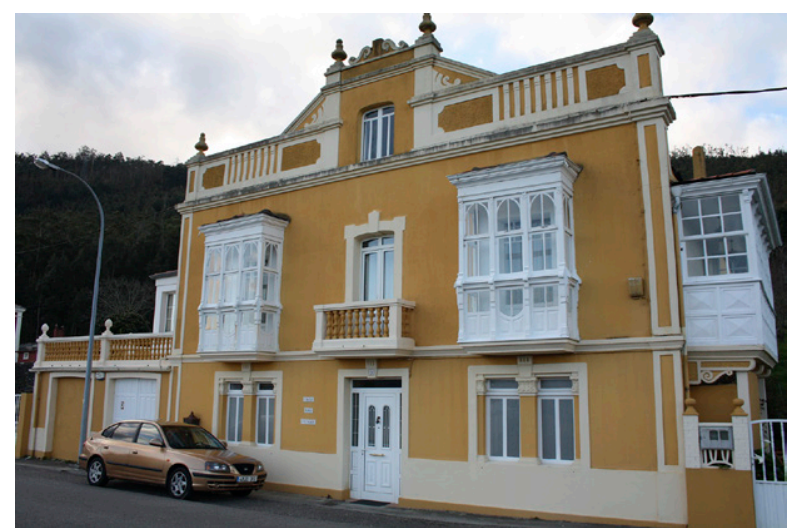

Casa das Veigas. 1928. Merille. Ourol, Lugo.

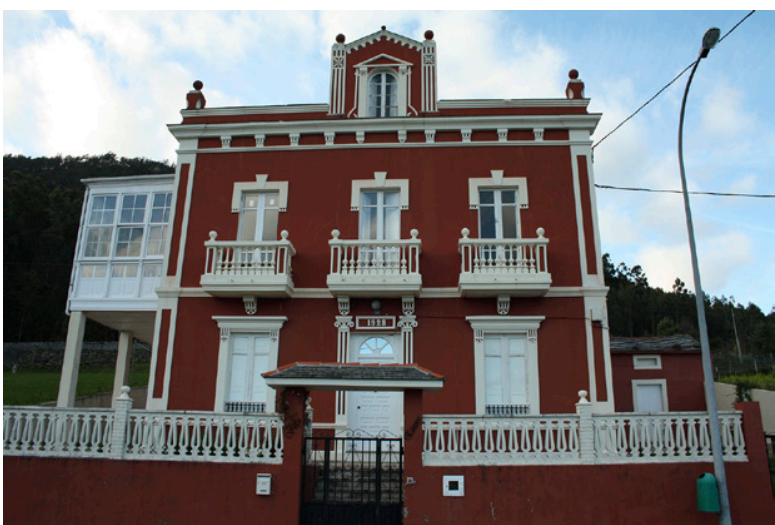

Casa Esteveri, 1928. Merille. Ourol, Lugo.

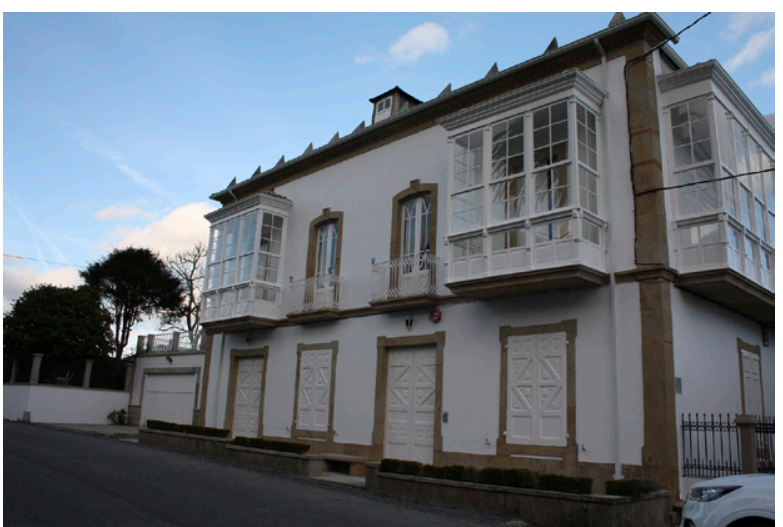

Casa de Puentes, 1922. Merille. Ourol, Lugo

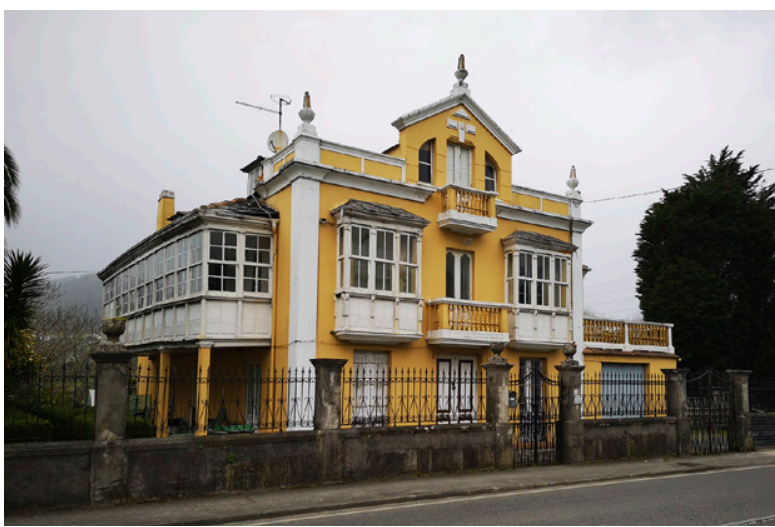

Casa do Esguello, ca. 1930. Magazos. Viveiro, Lugo.

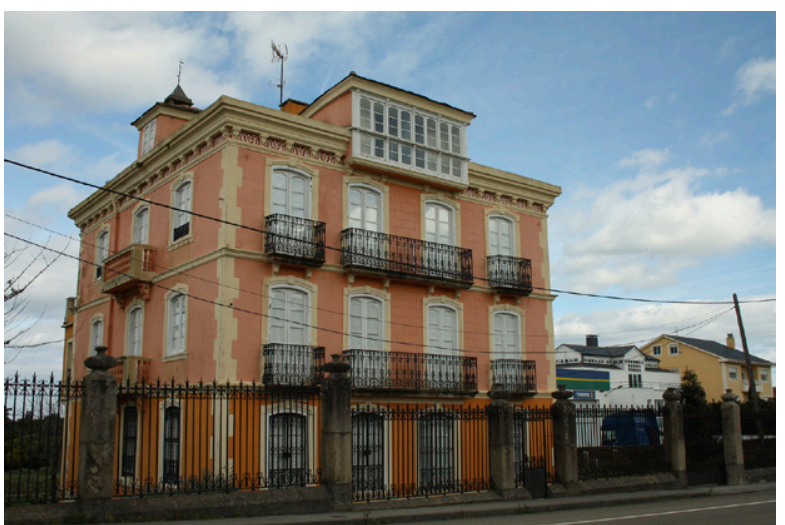

Casa de Carballo, finales s. XIX. San Cosme. Barreiros, Lugo. 


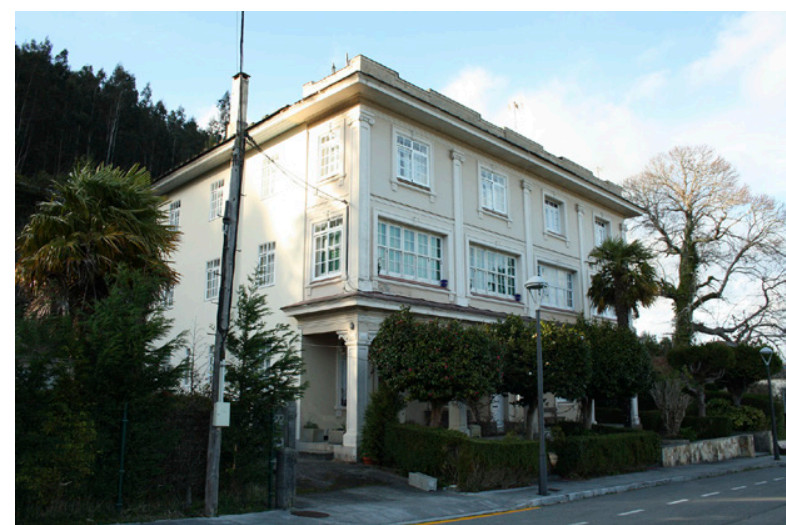

Casa de los Hermida, 1930. Ourol, Lugo.

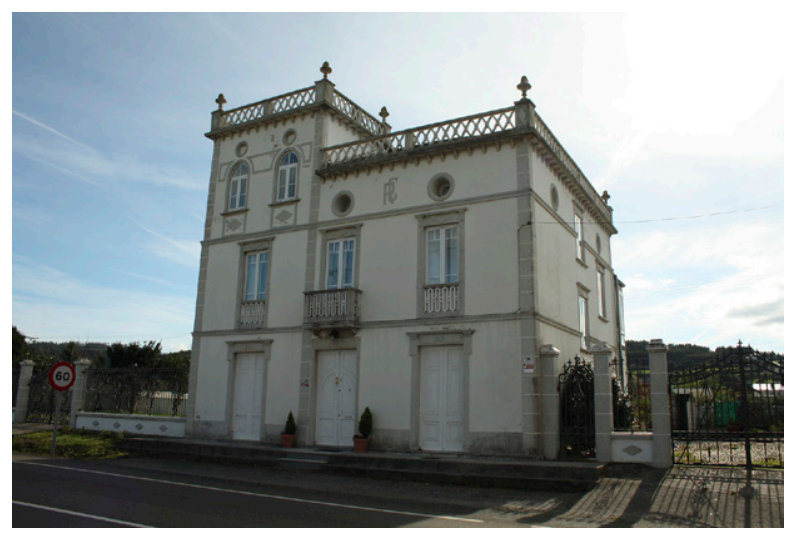

Villa Mosquera, 1933. Nois. Foz, Lugo.

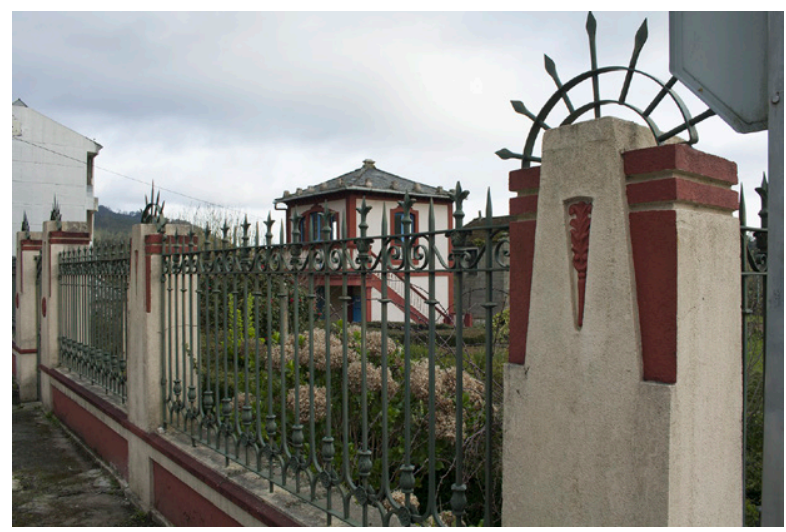

"O Cenador", 1925. Mondoñedo, Lugo.

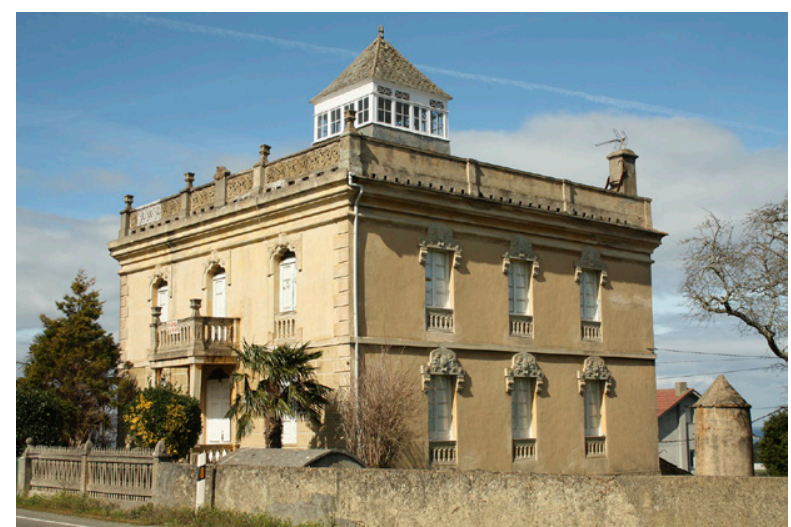

Casa Elena, ca. 1880. Reinante. Barreiros, Lugo.

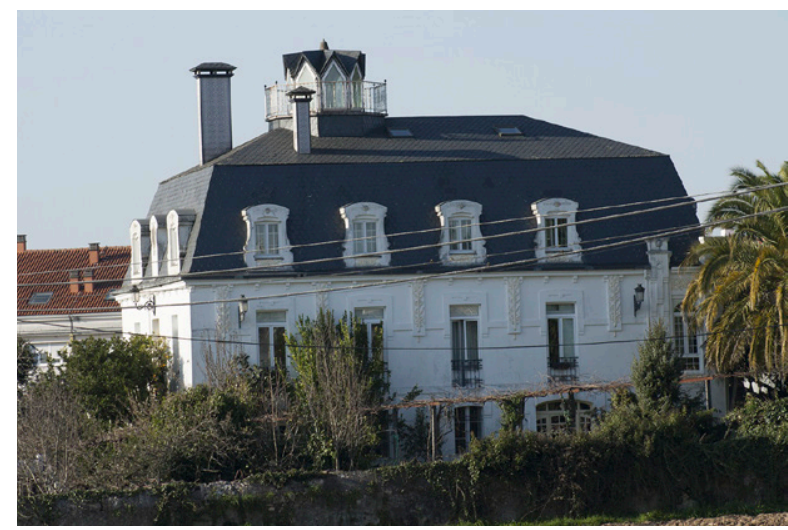

Casa en Lestedo, s/d. Boqueixón, A Coruña.

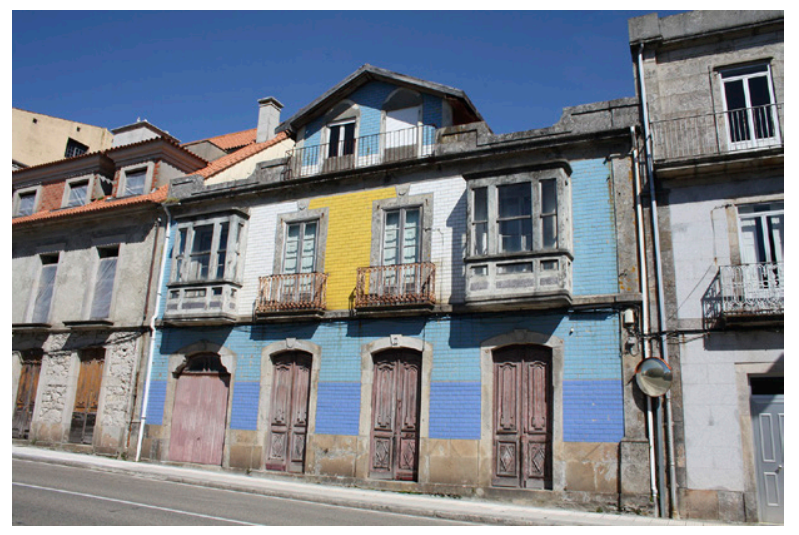

Casa de Higinio Troncoso Vicente. ¿1890? A Guarda, Pontevedra. 


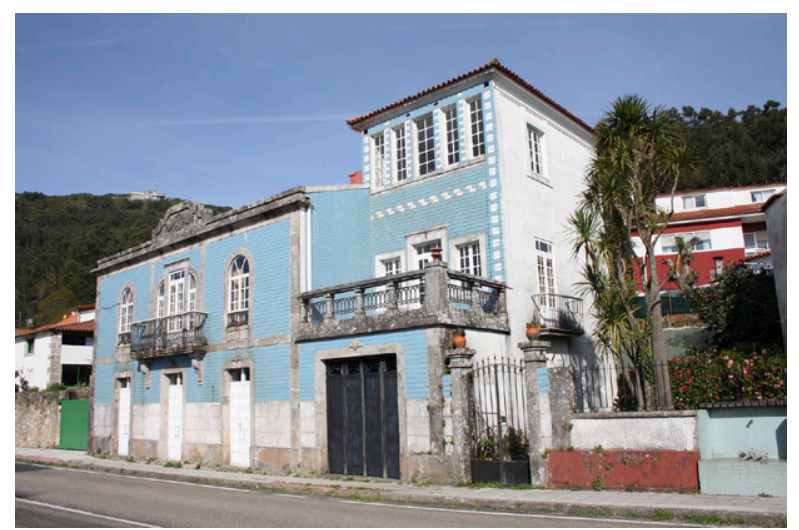

Casa de Domingo Domínguez Sabariz, ¿1922? Camposancos. A Guarda, Pontevedra.

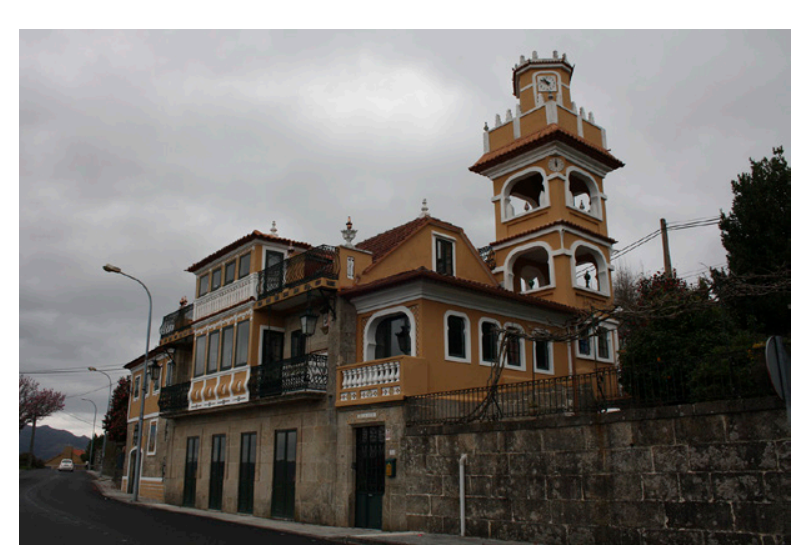

Casa Bella Vista, 1927. Insua. Ponte Caldelas, Pontevedra.

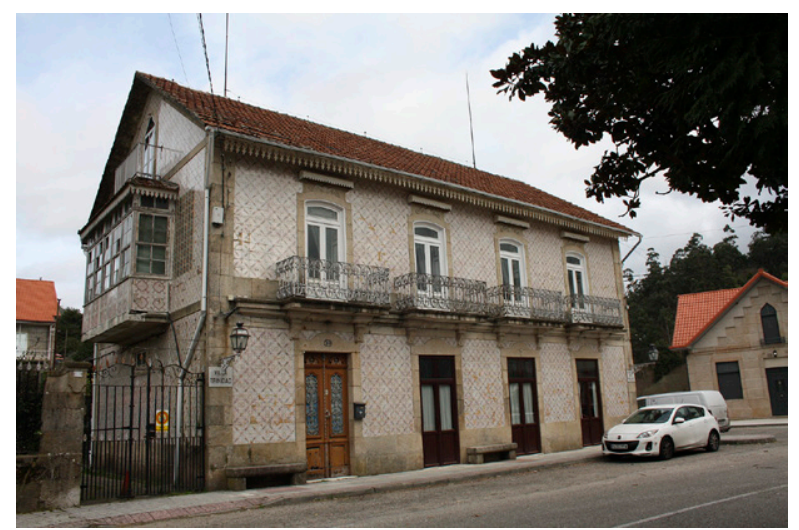

Villa Trinidad, 1907. Gaxate. A Lama, Pontevedra. 